\title{
Bulgaria’s Integration into the Pan-European Economy and Industrial Restructuring •/
}

\author{
Bartlomiej Kaminski \\ University of Maryland, College Park and World Bank \\ Francis Ng \\ Development Research Group - Trade, World Bank, Washington, D.C.
}

\begin{abstract}
This paper looks at Bulgaria's industrial restructuring through the lenses of its evolving specialization in international division of labor and integration into international markets with a special emphasis on EU markets. Its major findings can be summarized as follows: (i) Developments in Bulgaria's exports, its major drivers and factor content, during the 'second transition' following the 1996 crisis have become reminiscent of developments in the early 1990s in European transition economies that have stayed the reform course. (ii) Evolution of Bulgaria's total exports in terms of factor intensities before the 'second transformational' recession was a testimony to aborted economic reforms. It not only defied expectations derived from the experience of CEEC-10 economies and its production factor endowments but also dramatically increased the cost of adjustment to market conditions for the economy as a whole. (iii) Exports of unskilled labor intensive products continue towering over other exports even during the current expansionary phase. The composition of top performers in EU markets indicates, however, the shift toward natural resource and capital intensive products. Bulgaria's export offer in EU markets has budged toward more processed goods, mostly products of electro-engineering sectors. Subsequently, Bulgarian producers have made some strides in information communication technology products and automotive parts. Trade in parts and engineering products has also displayed strong growth.

The returns usually associated with liberal reforms, i.e., gains in competitiveness combined with a shift toward products in line with the country's endowments in production factors began to surface only recently. In contrast to the period preceding the second transformational recession, gains in competitiveness derive from corporate and industrial restructuring and not from subsidies.
\end{abstract}

Key words: integration, foreign trade, network trade, parts and components, production sharing, factor intensity, foreign direct investment, industrial restructuring, PanEuropean markets.

World Bank Policy Research Working Paper 3863, March 2006

The Policy Research Working Paper Series disseminates the findings of work in progress to encourage the exchange of ideas about development issues. An objective of the series is to get the findings out quickly, even if the presentations are less than fully polished. The papers carry the names of the authors and should be cited accordingly. The findings, interpretations, and conclusions expressed in this paper are entirely those of the authors. They do not necessarily represent the view of the World Bank, its Executive Directors, or the countries they represent. Policy Research Working Papers are available online at http://econ.worldbank.org.

\footnotetext{
- Background report prepared for Bulgaria: Country Economic Memorandum. The authors are grateful to Rosalinda Quintanilla, Stella Ilieva, Gallina Vincelette and Juan Carlos Ginarte for long discussions, useful comments and suggestions.
} 


\section{Table of Contents}

1. Introduction 4

2. Highlights of Bulgaria's trade performance: dynamics and geographical reorientation .... 6

A. Trade in goods and services: three phases ............................................................................ 6

B. Performance: exports of goods in comparative perspective ...................................................... 8

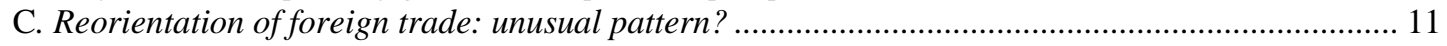

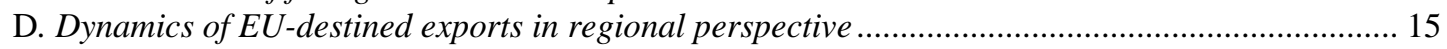

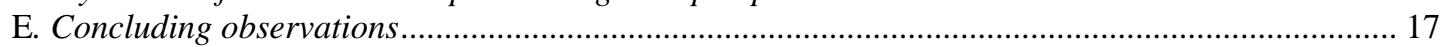

3. Commodity composition of trade and the degree of processing.................................... 17

A. Changes in the composition of imports....................................................................................... 17

B. Degree of processing embodied in EU-oriented exports: end-use product categories................... 20

C. Level of technology embodied in EU-oriented exports and competitiveness .................................. 21

D. Emerging top export performers in EU markets........................................................................ 22

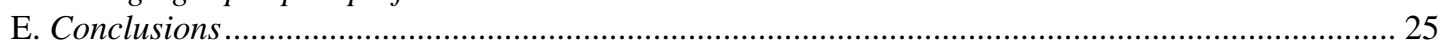

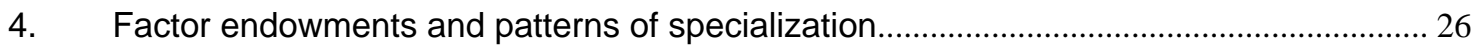

A. Bulgaria's endowment in factors of production ...................................................................... 26

B. Factors content of Bulgaria's exports in comparative perspective ............................................. 27

C. What do developments in trade with the EU say about labor markets? ..................................... 31

D. Factors' content and emerging patterns of specialization in EU markets.................................... 32

E. Factors content of EU-oriented exports and level of technology ................................................ 34

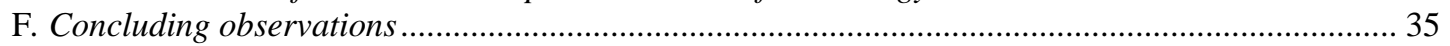

5. Integration into EU production structures: participation in EU-driven value chains ........ 35

A. Participation in 'buyer-driven' value chains: clothing, footwear and furniture ............................ 37

B. 'Producer-driven' chains: automotive and information technology networks .............................. 40

C. Bulgaria's producer-driven network trade in regional perspective.............................................. 43

D. Other forms of outsourcing: exports of parts and other engineering products together with parts 44

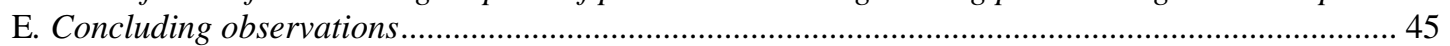

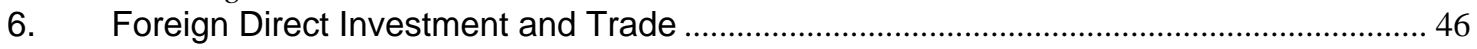

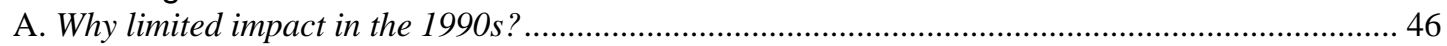

B. Lesson from other transition economies: reason for optimism with a caveat................................ 48

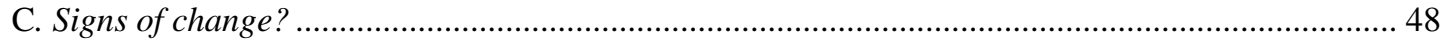

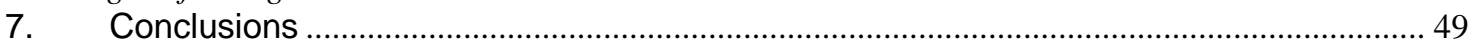

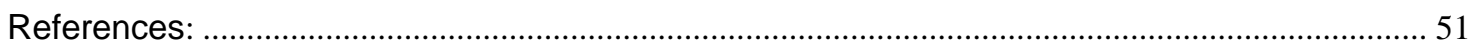




\section{Tables}

Table 1; Developments in trade in goods and services in 1992-2003 (in millions of current US dollars) ....................... 7

Table 2: The collapse of output and dependence on "socialist trade".

Table 3: Share of Bulgaria's exports of goods in total exports of regional groupings: CEEC-11, CEEC-3 and Stability Pact economies in 1996-2004 (in percent and millions of US dollars).

Table 4: Total trade turnover, exports and imports: EU-15 and Rest of World in 1992-2003 (in millions of US dollars and percent)

Table 5: Two statistical images of Bulgarian exports: total, EU-oriented, Belarus and CIS together with Baltic States (in millions of US dollars and percent)....

Table 6: Share of the EU-15 in Bulgaria's total exports and Romania's total exports in 1993-2003...in

Table 7: Direction and dynamics of Bulgaria's exports in 1996 \& 1999-2003 (in millions of US dollars and percent) 14

Table 8: Direction and dynamics of Bulgaria's imports in 1996 \& 1999-2003 (in millions of US dollars and percent) 15

Table 9: Share of Bulgaria, CEEC-8 and SEE-5 in EU-15 external imports in 1993, 1996-97, 2000 and 2003 (in percent)

Table 10: Bulgaria's imports by end-use product categories: total pan-European partners and ROW in 1996 and 2000-2003(in millions of US dollars and percent).

Table 11: "Technology content" of Bulgaria's manufactured imports from Pan-European area in 1996-2003 (in millions of US dollars and percent)

Table 12: Exports of end-use products in terms of their imports in $1996-2003$ (in percent)

Table 13: EU-oriented exports by end-use product categories in 1996-2003(in millions of US dollars): composition and share in EU imports (in percent).

Table 14: Share of the EU-15 and pan-European partners in Bulgaria's exports in 1996-2003 (in percent)

Table 15: EU-oriented exports of manufactures by the type of technology involved in their production in 1996-2003 (in percent).....

Table 16: Top twenty four-digit SITC exporters to the EU in 2003 and their rankings in 1996, 1999 and 2002........... 23

Table 17: Composition of fastest growers (above 30 percent on average over 2000-03) in EU markets by End-Use (in millions of US dollars and percent)

Table 18: Ten four-digit SITC sectors with the highest growth in exports in 2000-03.............................................. 24

Table 19: Top four export performers in electro-engineering products in EU markets in 1996-2003 (in thousands of US dollars)

Table 20: Bulgaria's endowments in comparative perspective: CEEC-11 and EU-15 ............................................ 27

Table 21: The differences between Bulgaria's exports and other CEEC-and SEE-economies in terms of factor intensities in 1996, 2000 and 2003 (in percentage points and in percent) ...................................................... 30

Table 22: Change in shares and dynamics of total exports in comparative perspective in 1996-2003 (in percent) ....... 30

Table 23: Dynamics of EU-oriented exports in terms of factor intensities (in percent) ....................................................32

Table 24: EU-oriented exports in terms of factor intensities in 1991-2003(in millions of US dollars and percent)....... 33

Table 25: Composition of 'most dynamic' EU-oriented exports and rates of growth in 2000-03 (in percent) ................ 33

Table 26: Composition of exports by the type of technology involved in their production, their share and export specialization index and their changes in 1996-2003 (in percent).

Table 27: Share of clothing in exports of manufactured goods excluding chemicals in 1992-2002 (in percent)

Table 28: Trade with the EU in 'buyer-driven' chains in 1996-2003 (in millions of US dollars and percent) ............... 39

Table 29: Bulgaria's involvement in furniture network in comparative perspective in 1996, 1999 and 2003 ................ 40

Table 30: Total exports of producer-driven networks in 1996-2003 (in millions of US dollars) ................................... 41

Table 31: Trade with the EU in 'producer-driven' chains in 1996-2003 (in millions of US dollars and percent).......... 42

Table 32: Features of 'producer-driven' network trade of CEEC-10 and SEE-5 economies in 1996, 1999 and 2003 (in percent).....

Table 33: Exports of parts and other engineering products and their share in EU external imports and Bulgaria's EUoriented exports in 1996-2003 (in millions of US dollars and percent)....

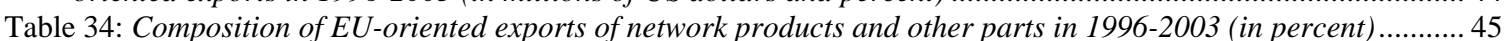

Table 35: FDI inflows to Bulgaria and CEEC-10 countries in 1991-96, 1997-1999 and 2000-2003.............................46

Table 36: Sectoral composition of FDI flows in 1998-2003 (in percent) ...................................................................47

Table 37: Share of Gross Domestic and Foreign Direct Investment in GDP in 1998-2003 (in percent) .......................48

Figures

Figure 1: Total exports of goods of Bulgaria, Hungary and Romania in 1993-2003 (in millions of US dollars)...........8

Figure 2: Bulgaria's non-EU and EU-15 oriented exports in 1992-2003 (in millions of US dollars) ............................12

Figure 3: Annual change in shares in EU external imports in 1993-2003 $(1999=100)$............................................ 16

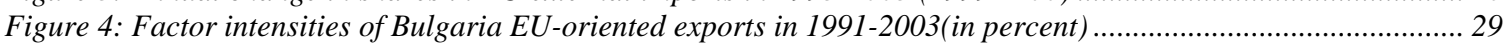




\section{Introduction}

Successfully competing in the global marketplace is crucial to sustained economic growth and poverty reduction. It requires macrostability, exposure to competition from imports, investment in infrastructure and cutting down production and transaction costs. The latter, synonymous with business climate, demand cracking down on corruption and cutting down red tape. Unshackling entrepreneurs from excessive bureaucratic restraints grants them the potential to increase their exports in sectors where they have competitive strength.

The experience of transition economies that have successfully taken advantage of opportunities offered by pan-European markets suggests that good institutions and policies combined with macrostability have to be in place. How can these elements be put in place? The first step is a successful implementation of first-generation reforms (liberalization of prices, foreign trade and exchange regimes). The second step entails an unwavering movement towards a rule-based institutional regime together with the development of state enforcement capacity. The former is relatively easy to implement, provided absence of political opposition, whereas the latter requires advanced institutional capacity of the state.

While Bulgaria moved swiftly in implementing first-generation reforms already in 1991 (Bruno 1994), the initial bold program of dismantling central planning and overcoming transformational recession had been quickly aborted distorted with the re-introduction of central controls. ${ }^{1}$ To make things worse, progress towards creating institutional conditions conducive to development driven by private entrepreneurial dynamism has been uneven since the collapse of central planning in 1989-90. It appears that weaknesses in state capacity combined with state's capture by private interests groups stood in the way of moving fast in structural reforms until the 1996 financial collapse. Its consequence was another transformational recession, with two consecutive years, 1996 and 1997, of falling aggregate output. Bulgaria, together with Romania and Moldova, are the only transition economies that experienced the second transformational recession, i.e., at least two consecutive years of contracting aggregate output. ${ }^{2}$

Hence, the real transition to competitive markets began only in 1997. In contrast to the first aborted transition, however, the conditions under which the second stabilization program was launched in 1997 were much more adverse and demanding than the ones accompanying the first stabilization program in 1991. For one, almost half decade of mismanagement wiped away financial sector and led to a massive stripping of assets of state owned firms. Many state-owned firms, which five years earlier might have been successfully privatized, lost attraction to potential investors, foreign and domestic alike. Furthermore, human capital skills that were still available in the early 1996 either disappeared due to migration or were simply depleted because of lack of employment opportunities.

In consequence, it took much longer for the usual returns from macrostability, privatization and liberalizing structural reforms to materialize. Delayed—almost a decade into transition - structural reforms combined with historically high dependence on 'socialist trade' had deeply affected Bulgaria's path of restructuring and integrating into world markets. While initially Bulgaria progress away from central planning appeared to be similar in terms of macroeconomic and export performance to that of other bold reformers, the differences surfaced rather dramatically during and immediately after the second transformational recession. The abolition of state monopoly over foreign trade combined with the collapse of 'socialist markets'

\footnotetext{
${ }^{1}$ For in-depth analysis of Bulgaria’s reform record, see Kaminski (2005) and Wyzan (1998).

2 Technically, the Czech economy also experienced two consecutive years of falling aggregate output in 1997-98. But the contraction of 0.8 percent and 1 percent was just a fraction of the fall experienced in a single year by Bulgaria, Moldova or Romania.
} 
initially resulted in impressive reorientation of exports, albeit from very low levels, to EU markets. However, stagnation replaced initial growth in 1996-99. Had it not been for the rapid expansion of clothing exports under the EU-driven outward processing, total exports would have significantly contracted. But in the most recent period, especially 2002-03, other products emerged as the levers of export growth. This indicates that liberalization measures have led to industrial and corporate restructuring and are beginning to pay off in terms of competitive gains in international markets.

While an unfinished reform of the economic regime, derailed until the 1996 financial crisis, was responsible for lackluster foreign trade performance, the 2000-2004 period witnessed improvements in export performance indicating that with unavoidable delay liberal reforms have activated some creative restructuring. In fact, there are three reasons for optimism. First, although one might have expected a stronger rebound in Bulgaria's exports after a contraction in 1998-99, current performance points to a significant improvement in the ability of Bulgarian producers to withstand competitive pressures in global markets. This refers also to their competitiveness in a single European market for industrial products. Particularly noteworthy is the fact that the largest increases occurred in 2002 and 2003. The rates of export growth of 12 percent and 31 percent respectively, albeit the latter 'tainted' by coincided with the significant increase in intensity of competition in preferential markets due to the removal of all tariffs on industrial products among signatories of the Pan-European Cumulation of Origin Agreement. ${ }^{3}$

Second, progress in implementation of structural reforms and converging to the EU "acquis communautaire" has led to a significant enhancement in the quality of domestic business climate, which augurs well for future trade performance. The European Commission declared Bulgaria a fully functioning market economy in 2003, and accession negotiations were successfully completed on June 15, 2004.

Last but not least, there has been a significant increase in FDI inflows accounting on average for around 8 percent of the GDP over 2000-2003. The earlier experience of other transition economies indicates that they had led to export expansion driven mainly by skilled labor and capital intensive products. There are indications that this change has been taking place in Bulgaria's exports, albeit clothing and footwear still dominate its export basket.

Hence, thanks to structural reforms and liberal regional trading environment, Bulgaria has successfully, albeit only belatedly, begun taking advantage of opportunities offered by participation in the EU-driven Eastern Enlargement regional integration project.

This paper looks at Bulgaria's industrial restructuring through the lenses of its evolving specialization in international division of labor and integration into international markets with a special emphasis on EU markets. Its major findings can be summarized as follows:

- Developments in Bulgaria's exports, its major drivers and factor content, during the 'second transition' following the 1996 crisis have become reminiscent of developments in the early 1990s in European transition economies that have stayed the reform course.

- Evolution of Bulgaria's total exports in terms of factor intensities before the 'second transformational' recession was a testimony to aborted economic reforms. It not only defied expectations derived from the experience of CEEC-10 economies and its production factor endowments but also dramatically increased the cost of adjustment to market conditions for the economy as a whole.

- $\quad$ Exports of unskilled labor intensive products continue towering over other exports even

\footnotetext{
${ }^{3}$ The Agreement has paved the way for establishment in 2002 of a single European trading bloc for industrial products, encompassing the EU-25, EFTA, Bulgaria, Romania and Turkey.
} 
during the current expansionary phase. But there are several indications heralding change underway:

$\checkmark$ The composition of top performers in EU markets (with an increase in EU imports of at least 2.85 times between 2000 and 2003), accounting for 16 percent of Bulgaria's EU-oriented exports in 2003 up from 4 percent in 2000, indicates the shift towards natural resource and capital intensive products.

$\checkmark$ Bulgaria's export offer in EU markets has shifted towards more processed goods mostly products of electro-engineering sectors.

$\checkmark$ Although Bulgarian producers are not yet become on any significant scale of the division of labor based on production fragmentation in vertically integrated sectors, they have made significant strides in information communication technology products and automotive parts.

$\checkmark \quad$ Last but not least, trade in parts and engineering products not covered by the network trade analysis has displayed strong growth, with their exports accounting in 2003 for 5.4 percent of Bulgaria’s EU-oriented exports up from 3.1 percent in 1998.

- $\quad$ The returns usually associated with liberal reforms, i.e., gains in competitiveness combined with shift towards in products in line with country's endowments in production factors began to surface only recently. In contrast to the period preceding the second transformational recession, gains in competitiveness derive from corporate and industrial restructuring and not from subsidies.

\section{Highlights of Bulgaria's trade performance: dynamics and geographical reorientation}

What are the major characteristics of Bulgaria's overall performance? How does it compare to other regional partners? What are its idiosyncratic features? These are the main questions addressed in this section.

\section{A. Trade in goods and services: three phases}

Looking solely at the dynamics of Bulgaria's foreign trade over 1990-2004, one may distinguish three distinct phases. The first phase of hesitant recovery, covering the period in the aftermath of the collapse of central planning in 1989-90 until 1995, was characterized by a slow growth in the value of both exports and imports. The value of total trade increased 60 percent between 1991 and 1995, with a caveat-balance of payments statistics for this period are hardly reliable. Trade in services, which increased more than threefold, contributed significantly to the increase, as trade in goods increased only 40 percent during this period (Table 1).

The beginning of the second phase of stagnation, if not contraction, coincides with the eruption of financial crisis in 1996 and ends in 1999. Within this second phase, the deep macroeconomic crisis that brought the economy to a grinding halt in 1996-97 affected foreign trade in perverse ways. While in 1996 both the values of exports and imports contracted, the former increased in 1997 (Table 1). This led to a very significant surplus in foreign trade, with the value of exports of goods and services 20 percent higher than their imports. Surpluses disappeared in both 1998 and 1999, as exports were contracting and imports increased in both years. ${ }^{4}$ In consequence, in 1996 total foreign trade in goods and services fell more than the GDP - in 1995 the ratio fell from 137 percent to 97 percent in 1996. Subsequently, the foreign trade contracted less than the GDP in 1997 and grew faster in 1998. In 1999, when the GDP

\footnotetext{
${ }^{4}$ Although the value of exports of goods and services increased in 1997 over 1996, the value of imports fell much more. In consequence, the total trade declined in 1997 marking the beginning of the stagnation and contraction in Bulgaria's foreign trade.
} 
registered healthy growth after two years of contraction, total trade-due to the decline in the value of exports-contracted in terms of their share in the GDP.

Table 1; Developments in trade in goods and services in 1992-2003 (in millions of current US dollars)

\begin{tabular}{|c|c|c|c|c|c|c|c|c|c|c|c|c|c|}
\hline & 1991 & 1992 & 1993 & 1994 & 1995 & 1996 & 1997 & 1998 & 1999 & 2000 & 2001 & 2002 & 2003 \\
\hline $\begin{array}{l}\text { Exports of goods and } \\
\text { services }\end{array}$ & 4,137 & 5,026 & 4,898 & 5,192 & 6,738 & 6,608 & 7,011 & 5,981 & 5,795 & 7,000 & 7,539 & 8,286 & 10,590 \\
\hline of which: services & 400 & 1,070 & 1,172 & 1,257 & 1,771 & 1,919 & 2,202 & 1,788 & 1,788 & 2,175 & 2,426 & 2,594 & 3,115 \\
\hline $\begin{array}{l}\text { Imports of goods } \\
\text { (fob) and services }\end{array}$ & 4,255 & 5,334 & 5,841 & 5,198 & 6,636 & 6,152 & 5,845 & 5,989 & 6,562 & 7,670 & 8,575 & 9,287 & 12,151 \\
\hline Of which: services & 486 & 1,165 & 1,229 & 1,246 & 1,706 & 1,585 & 1,357 & 1,415 & 1,474 & 1,670 & 1,882 & 2,000 & 2,439 \\
\hline Balance in total trade & -118 & -308 & -943 & -6 & 102 & 456 & 1,166 & -8 & -767 & -670 & $-1,036$ & $-1,001$ & $-1,561$ \\
\hline In goods & -32 & -213 & -886 & -17 & 37 & 122 & 321 & -381 & $-1,081$ & $-1,175$ & $-1,580$ & $-1,595$ & $-2,237$ \\
\hline In services & -86 & -95 & -57 & 11 & 65 & 334 & 845 & 373 & 314 & 505 & 544 & 594 & 676 \\
\hline $\begin{array}{l}\text { Exports of goods and } \\
\text { services as percent of } \\
\text { their imports }\end{array}$ & 97.2 & 94.2 & 83.9 & 99.9 & 101.5 & 107.4 & 120.0 & 99.9 & 88.3 & 91.3 & 87.9 & 89.2 & 87.2 \\
\hline $\begin{array}{l}\text { Exports of goods as } \\
\text { percent of their } \\
\text { imports }\end{array}$ & 99.1 & 94.9 & 80.8 & 99.6 & 100.8 & 102.7 & 107.2 & 91.7 & 78.8 & 80.4 & 76.4 & 78.1 & 77.0 \\
\hline $\begin{array}{l}\text { Share of services in } \\
\text { exports }\end{array}$ & 9.7 & 21.3 & 23.9 & 24.2 & 26.3 & 29.0 & 31.4 & 29.9 & 30.9 & 31.1 & 32.2 & 31.3 & 29.4 \\
\hline $\begin{array}{l}\text { Total trade in goods } \\
\text { and services in GDP }\end{array}$ & 76.7 & 94.7 & 103.5 & 95.9 & 136.7 & 97.4 & 129.8 & 115.4 & 97.0 & 113.2 & 127.8 & 129.3 & 146.8 \\
\hline
\end{tabular}

Source: Bulgarian authorities and Fund staff estimates.

Yet, in retrospect, the contraction in exports of goods in 1999, triggered by long delayed industrial restructuring, set the stage for a strong recovery phase that began a year later. An indication of restructuring was the growth in imports of machinery. Their share in total imports increased from 14 percent of total imports in 1997 to 16 percent in 1998 and jumped to 21 percent in $1999 .{ }^{5}$ Year 2000 witnessed a turnaround in both exports and imports. Since 2000 trade in goods and services has expanded faster than the GDP, reversing the developments in 1996 and 1998-99.

Notwithstanding low reliability of data on trade in services, usually underreported in most balance of payments statistics, services appear to have been a bright spot in Bulgaria's external performance. First, it has been a net foreign currency earner, with the surplus reaching US\$ 676 million in 2003. Except for a short period in 1995-1997 coinciding with the 1996-97 financial melt-down, Bulgaria ran a deficit in its trade in goods and services. Exports of goods as percent of their imports have been at slightly below 80 percent since 1999.

Second, in contrast to exports of goods, the contraction in exports of services during the 1996-99 crisis phase was much smaller and extended over a shorter period of only two years, that is, 1996 and 1997. They began rebounding in 1998, but they exceeded the pre-crisis level only in 2001. The share of services in Bulgaria's total exports of goods and services increased from 22 percent in 1996 to 30 percent in 2003, with the share of travel in foreign exchange receipts from services growing from 28 percent to 52 percent over this period.

Yet, there is still a significant untapped potential to increase earnings in the future. The IMF projects strong growth of exports of services over 2004-06 mainly due to tourism revenues. It predicts a 24 percent growth in exports of travel services in 2004 and a ten-percent increase in 2005 (IMF 2004).

Another reason for optimism relates to current and future exports of computer services. While the quality of statistics is particularly poor in this sector, simply because cross-border

\footnotetext{
${ }^{5}$ Machinery is defined as items in SITC. 7 (excluding automobiles). Own calculations based on foreign trade data reported by Bulgaria to the UN COMTRADE database.
} 
supplies of these services tend to be beyond government's control, there are some indications pointing to a healthy growth of software exports mainly to the EU and U.S. According to one estimate and anecdotal evidence, around 80 percent of Bulgaria's software output of estimated at around US\$ 400 million, or around US\$ 340 million, is sold abroad. ${ }^{6}$ Since the total value of 'other services' sold abroad was US\$ 565 million in 2003, it is rather unlikely that this fully accounts for the contribution of the software sector. According to the same source, these exports are expected to grow at around 30 percent per year over the next several years.

\section{B. Performance: exports of goods in comparative perspective}

Bulgaria stands out among CEEC-10 economies as the worst performer in terms of exports of goods. No other CEEC-10 economy has experienced such a volatile export performance and such deep contraction not only immediately after the collapse of central planning but also several years into transition. Bulgaria's time profile makes it more comparable to CIS economies rather than to CEEC-8 but only in its performance through early 1990's. It became comparable to that of CEEC-8 economies experienced during their early stages of transition only 6-7 years later around 1997.

Bulgaria's overall performance in 1991-95 appeared to be in line with that of other Central European economies. Data in Figure 1 for two countries, Hungary and Romania with total exports (US\$ 5.2 billion and US\$ 4.9 billion) roughly twice as large as total exports of Bulgaria (US\$ 2.3 billion) in 1993, provide vivid illustration of distinctive features of Bulgaria's export performance. ${ }^{7}$ The differences in dynamics were enormous. By 2004 Hungary's total exports stood at 179 percent of Romania's exports and 442 percent of Bulgaria's, while Romania's at 246 percent of Bulgaria's exports.

Figure 1: Total exports of goods of Bulgaria, Hungary and Romania in 1993-2003 (in millions of US dollars)

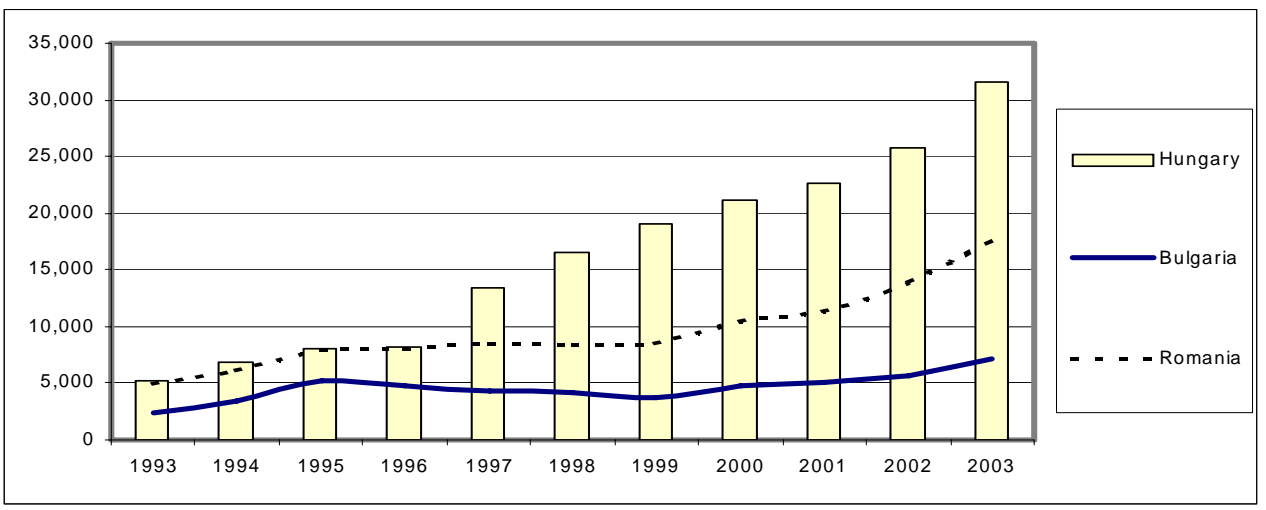

Source: Derived from the IMF Direction of Trade statistics.

While the value of Bulgaria's exports increased 125 percent between 1991 and 1995 as compared to Hungary's 56 percent and Romania's 62 percent, the recovery from a transformational recession turned out to be short-lived. There was a dramatic reversal of fortunes in 1996-99, with total exports in terms of value falling every year during this period. The largest contraction of almost 10 percent was in 1997. While the value of Bulgaria's total exports in 1999

\footnotetext{
${ }^{6}$ As reported in IntelliNews - Bulgaria Today, March 25, 2005 (07:02)

${ }^{7}$ Note that the data used in Figure 1 differ from those in Table 1, as they are derived not from the balance of payments statistics but from the IMF direction of trade statistics.
} 
stood at 72 percent of their 1995 value, Romania stood at 107 percent and Hungary's exports skyrocketed to 236 percent of their 1995 level.

Although in 2000-03 the time profile of developments in exports of these countries has become roughly similar, with Bulgaria's growth on par with that of Hungary and below that of Romania, the losses incurred in 1992-96 turned out to be very difficult to recover. Romania's export growth during the 1999-2003 was much stronger than that of Bulgaria. The gap between these two countries has been increasing in favor of Romania every year since 1995. During Romania's recent expansionary period over 1999-2003, Romanian exports recorded the third fastest growth among European transition economies. ${ }^{8}$

The differences between three countries stem from differences in economic policies. Hungary, which consistently stayed the reform course, outperformed both Bulgaria and Romania. While there were not significant differences in approach taken initially to economic reforms, Bulgaria had a clear disadvantage, i.e., huge sovereign debt incurred before the collapse of central planning. In addition, it had looser macroeconomic policies and state owned enterprises had easier access to bank credits.

The seeds of subsequent economic collapse of Bulgaria in 1996, planted several years earlier, were apparent in three important features in Bulgaria's export performance prior to the crisis that set it apart from Central European radical reformers. First, exports to the EU contributed much less to overall export recovery than in CEEC-3 economies (see Section 2.C below). Second, different products in terms of factor intensities drove the overall export recovery. Last but not least, Bulgaria's export performance turned out to be non-sustainable over a longer period of time, as exports collapsed in 1996 setting Bulgaria apart not only from CEEC-3 countries, but also Romania.

The reasons for the collapse were rooted in aborted first-generation reform measures and the absence of structural, second-generation reforms. More specifically, the failure to introduce hard-budget constraint on SOEs combined with various schemes of privatizing stream of benefits from state-owned assets has led to the meltdown of the banking sector and the collapse of the economy. Consider first that the Bulgarian 'melt-down' in 1996-97 cannot be explained by historically high dependence on 'socialist trade.' For instance, Baltic States were more dependent on this trade than Bulgaria and experienced higher decline in output (Table 2). But none of them experienced the second transformational recession, as all the contraction occurred during the period following immediately the demise of central planning.

Although there appears to be a strong positive correlation between the size of contraction in output and the share of CMEA exports before the demise of the CMEA, the "pre-transition" level of dependence on socialist markets fails to explain considerable variation in output decline among CEEC-10. This seems to suggest that policies did play an important role. Consider the following. Despite its low level of trade with CMEA countries in 1989, the contraction in Romania's output was higher than that of several other CEECs (e.g., Hungary and Poland) with much higher exposure to CMEA markets. Bulgaria registered similar contraction in output as Estonia, albeit the latter was much more heavily depended on socialist trade. Hence, reforms and good policies appear to have weakened the negative impact of initial conditions.

Yet, their absence raised the cost of adjustment. Consider first that higher level of dependence on trade with CMEA suggest that a much larger share of industrial output would face more challenging conditions of switching sales to 'real' fully contestable world markets. Second, the absence of shift to hard budget constraint was bound to create not only rapidly expanding

\footnotetext{
${ }^{8}$ For an extensive discussion of Romania's trade performance and its drivers, see World Bank (2004) and Kaminski and Ng (2004).
} 
contingent macroeconomic liabilities but also incentives to managers to strip assets and design schemes to 'privatize' income from state-owned assets. Therefore, delays in implementing hard budget constraints and in privatization further eroded potential value of assets and dramatically raised the cost of transition from central planning in Bulgaria.

Table 2: The collapse of output and dependence on "socialist trade"

\begin{tabular}{|c|c|c|c|}
\hline & Last year in which output fell & $\begin{array}{l}\text { Cumulative output } \\
\text { decline since } 1990\end{array}$ & $\begin{array}{l}\text { The share of CMEA exports (or inter- } \\
\text { republic) in total exports in } 1989^{4} /\end{array}$ \\
\hline Bulgaria & 1997 & 41 & 53 \\
\hline Czech Republic ${ }^{1}$ / & 1998 & 16 & 37 \\
\hline Estonia ${ }^{3} /$ & 1999 & 52 & 98 \\
\hline Hungary & 1993 & 19 & 41 \\
\hline Latvia $^{3}$ / & 1995 & 57 & 97 \\
\hline Lithuania ${ }^{3} /$ & 1999 & 55 & 94 \\
\hline Poland & 1991 & 14 & 41 \\
\hline Romania & 1999 & 39 & 25 \\
\hline Slovak Republic ${ }^{1} /$ & 1993 & 27 & 37 \\
\hline Slovenia ${ }^{2} j$ & 1992 & 22 & 37 \\
\hline
\end{tabular}

Notes: ${ }^{1 /}$ the share of CMEA -oriented exports is for former Czechoslovakia in 1989.

2/ the combined share of exports to CMEA and Yugoslav republics in 1992.

3/ the share of exports to former Soviet republics in 1990.

$4 /$ The respective shares were re-calculated using Hungarian exchange rate for transferable ruble because the Hungarian rate better reflected the purchasing power of the transferable ruble than rates used by other CMEA partners (See Kaminski, Wang, Winters 1996).

Source: Fischer and Sahay (2000), Kaminski, Wang and Winters (1996), and WB 2005.

The most powerful indication that the failure of economic policies in 1990-96 to remove administrative barriers to allocation of resources and to introduce hard budget constraint on firms, mainly state owned, ${ }^{9}$ explains Bulgaria's unique pattern of export performance in that period relates to factor content of its exports. In contrast to factor intensities of Hungarian or Polish exports, capital intensive and skilled labor intensive products drove Bulgarian exports. While one would expect that-like first in Hungarian and subsequently in Polish exports - these products would become levers of the export growth, as this would be in line with their comparative advantage, this could not have occurred without prior industrial restructuring. In the case of Bulgaria, the bulk of exports in 1991-96 continued coming from state-owned firms. Their share in total output of industry in 1995 was still 88 percent. Operating at a loss, some of the state-owned firms were able to offer prices low enough to be competitive on the international markets. Subsidies facilitated competing through prices rather than quality. This explains why, in contrast to Bulgaria's endowments and available production assets poorly matching market imperatives, skilled labor and capital intensive experienced initially the fastest growth in EU-oriented exports. While in Hungary and Poland large chunks of industry, deprived of subsidies and "easy" markets at home, faced extinction or restructuring, there were no similar pressures in Bulgaria.

The loss in competitiveness vis-à-vis its regional partners, as a result of misguided economic policies in 1991-96, was very significant. Bulgaria's share in total exports of CEEC-11, i.e., European transition economies that either acceded or are on the accession path to the EU, fell from 5 percent in 1996 to 3 percent in 1999. Significant improvement in Bulgaria's performance has not been sufficient to allow for the increase in its share in total exports of not only CEEC-11 but also CEEC-3 (Table 3). Bulgaria has succeeded, however, to expand at the same pace as other countries of the Balkan Stability Pact (see notes to Table 3).

\footnotetext{
${ }^{9}$ Major measures of first-stage reforms were not only overturned but also no structural, second-stage reforms followed. Price liberalization was partly reversed and-with the capture of economic policy by powerful private vested interests - privatization program of large state-owned enterprises suspended. For a review of Bulgaria's decade of transition, see Mihov (1999). For an analysis of the 1996 crisis, see Dobrinsky (1997) and Wyzan (1998).
} 
Table 3: Share of Bulgaria's exports of goods in total exports of regional groupings: CEEC-11, CEEC-3 and Stability Pact economies in 1996-2004 (in percent and millions of US dollars)

\begin{tabular}{|l|rrrr|rrrrr|c|c|}
\hline & 1996 & 1997 & 1998 & 1999 & 2000 & 2001 & 2002 & 2003 & 2004 & $1996=100$ & $2000=100$ \\
\hline \hline In total CEEC-11 & 4.8 & 4.4 & 3.4 & 3.2 & 3.5 & 3.3 & 3.2 & 3.3 & 66 & 96 \\
In total CEEC-3 & 28.0 & 27.9 & 25.1 & 23.5 & 24.6 & 24.2 & 23.4 & 24.1 & 84 & 98 \\
In total "Stability" countries & 24.0 & 23.0 & 20.1 & 20.0 & 21.2 & 20.7 & 20.1 & 21.3 & 84 & 100 \\
Memorandum: exports & 4,890 & 4,940 & 4,293 & 3,925 & 4,822 & 5,114 & 5,749 & 7,540 & 80 & 156 \\
\hline
\end{tabular}

Notes: "Stability" countries include Albania, Bosnia and Herzegovina, Bulgaria, Croatia, Macedonia, Moldova, Romania and Serbia and Montenegro. Due to the missing data, Bosnia \& Herzegovina is based on IMF DOT data.

Sources: UN COMTRADE Statistics and IMF Direction of Trade Statistics.

In all, the grand failure of not staying the reform course following the introduction of the stabilization-cum-transformation program in 1991 seems to explain why Bulgaria's export performance in the 1990s is reminiscent of developments in CIS economies rather than of CEEC10 economies including Romania. Economic mismanagement of transition until the 1996 crisis has exacted a huge toll on the Bulgarian economy. Quickly abandoned radical approach to firstgeneration economic reforms locked Bulgaria, like most other CIS economies, into a path of partial reforms generating systemic corruption, plunder of state assets and ultimately producing a financial meltdown in 1996. Historically, high level of dependence on trade with CMEA countries had contributed to the high cost of adjustment. But had Bulgaria stayed the reform course in the early 1990s this cost would have been much smaller and spread over a shorter period of time, as the experience of Baltic States has clearly demonstrated. Macroeconomic stability and the pursuit of unfinished agenda of structural economic reform beginning in 1997 have been behind improved export performance in 2000-03.

\section{Reorientation of foreign trade: unusual pattern?}

The most striking features of Bulgaria's geographical pattern of foreign trade are the lack of increase in the share of the EU in total trade turnover since 1992 and reorientation of trade away from the EU in 1993-97 (Table 4). The share of the EU in total trade turnover was 51 percent in 1992 and 52 percent in 2003, as the shares of the EU in Bulgaria's exports and imports moved in opposite direction. The share in exports went up 11 percentage points while that in imports 12 percentage points.

Reorientation in Bulgaria's trade away from the EU in 1993-97 was driven by both exports and imports. The share of the EU in total trade turnover fell from 51 percent in 1992 to an average of around 40 percent during the 1993-97 period. It is interesting to note that this reorientation away from the EU appear to have coincided with the beginning of the second stabilization-cum-transformation program. Export reorientation, i.e., faster expansion in the growth of EU-oriented exports than in ROW-oriented exports, rather than import reorientation has been responsible for it.

As mentioned earlier, Bulgaria's geographical pattern of trade also diverged from other CEEC-10 economies. While non-EU exports of other CEEC-10 countries were falling during the initial stages of transition - in contrast to rapidly growing EU-oriented exports, Bulgaria's succeeded in expanding its non-EU exports-most notably to Belarus-more than EU-oriented exports in 1992-95 (Figure 2). 
Table 4: Total trade turnover, exports and imports: EU-15 and Rest of World in 1992-2003 (in millions of US dollars and percent)

\begin{tabular}{|c|c|c|c|c|c|c|c|c|c|c|c|c|c|c|}
\hline & 1992 & 1993 & 1994 & 1995 & 1996 & 1997 & 1998 & 1999 & 2000 & 2001 & 2002 & 2003 & $\begin{array}{c}\text { Index } \\
1995 \\
1992= \\
100\end{array}$ & $\begin{array}{c}\text { Index, } \\
2003 \\
2000= \\
100\end{array}$ \\
\hline & \multicolumn{12}{|c|}{ (total trade turnover in millions of US dollars) } & & \\
\hline EU-15 & 2,648 & 2,699 & 3,472 & 4,392 & 4,010 & 3,723 & 3,765 & 4,361 & 5,073 & 5,652 & 6,735 & 7,719 & 166 & 152 \\
\hline ROW & 2,511 & 3,965 & 4,408 & 5,548 & 6,239 & 5,482 & 4,264 & 4,439 & 4,907 & 5,772 & 6,078 & 7,266 & 221 & 148 \\
\hline \multirow[t]{2}{*}{ Total } & 5,159 & 6,664 & 7,880 & 9,940 & 10,250 & 9,205 & 8,030 & 8,799 & 9,980 & 11,424 & 12,813 & 14,985 & 193 & 150 \\
\hline & \multicolumn{12}{|c|}{ (in percent) } & & \\
\hline EU-15 & 51 & 41 & 44 & 44 & 39 & 40 & 47 & 50 & 51 & 49 & 53 & 52 & 86 & 101 \\
\hline \multirow[t]{2}{*}{ ROW } & 49 & 59 & 56 & 56 & 61 & 60 & 53 & 50 & 49 & 51 & 47 & 48 & 115 & 99 \\
\hline & \multicolumn{12}{|c|}{ (export shares in percent) } & & \\
\hline EU-15 & 45 & 47 & 47 & 46 & 39 & 40 & 45 & 51 & 54 & 52 & 55 & 56 & 103 & 104 \\
\hline ROW & 55 & 53 & 53 & 54 & 61 & 60 & 55 & 49 & 46 & 48 & 45 & 44 & 98 & 96 \\
\hline \multirow[t]{2}{*}{$\begin{array}{l}\text { Total (million } \\
\text { of US \$) }\end{array}$} & 2,051 & 2,444 & 2,319 & 3,400 & 5,220 & 4,781 & 4,314 & 4,150 & 3,755 & 4,760 & 5,062 & 5,631 & 166 & 150 \\
\hline & \multicolumn{12}{|c|}{ (import shares in percent) } & & \\
\hline EU-15 & 56 & 37 & 43 & 43 & 40 & 41 & 49 & 48 & 49 & 48 & 51 & 49 & 78 & 100 \\
\hline ROW & 44 & 63 & 57 & 57 & 60 & 59 & 51 & 52 & 51 & 52 & 49 & 51 & 128 & 100 \\
\hline $\begin{array}{l}\text { Total (million } \\
\text { of US \$) }\end{array}$ & 3,107 & 4,220 & 5,561 & 6,540 & 5,030 & 4,424 & 3,716 & 4,649 & 6,225 & 6,664 & 7,751 & 9,354 & 210 & 150 \\
\hline
\end{tabular}

Source: IMF Direction of Trade Statistics.

Figure 2: Bulgaria's non-EU and EU-15 oriented exports in 1992-2003 (in millions of US dollars)

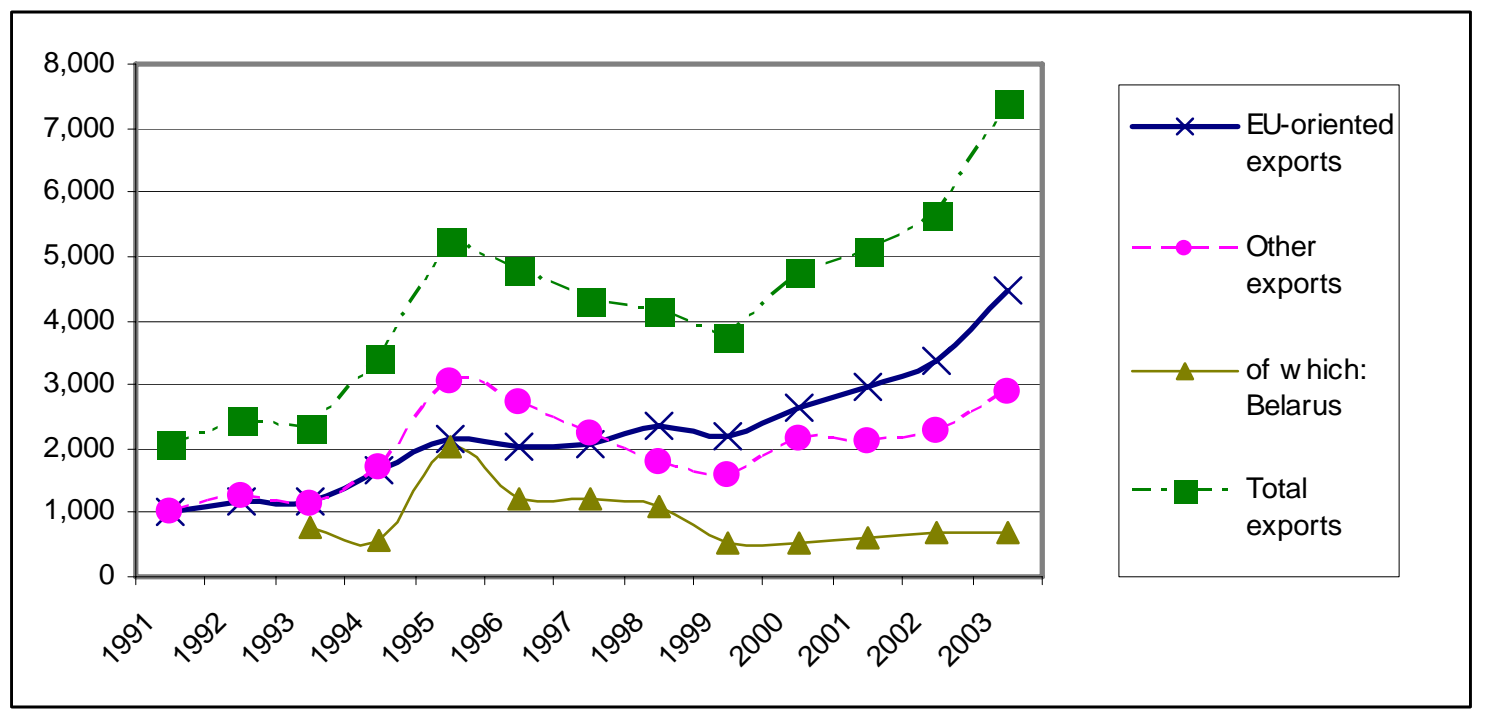

Source: Source: IMF Direction of Trade Statistics.

In fact, it appears from the IMF Direction of Trade statistics that exports to Belarus shaped Bulgarian exports over 1994-99 displaying an unusual pattern of magnitude and volatility. They soared from US\$ 570 million in 1994 to US\$ 2 billion in 1995, accounting for 81 percent of the annual increase in the value of total exports (Table 5). They fell rather precipitously in 1996 to a still respectable level of US\$ 1.2 billion and their value over 1997-98 was still above US\$ 1billion. The size of contraction (US\$ 831 million) was almost twice as large as the contraction in the value of total exports

Bulgarian National Bank's trade statistics do not back up the claim about unique Belarus' role in Bulgarian export. These statistics, available only since 1995, portray a different image. First, total Bulgarian exports to CIS and Baltic states combined were lower according to BNB 
statistics than exports to Belarus alone. The differences were rather staggering: IMF-reported exports were 2.3-times, 1.3-times, 1.4 times, 2.1 times and 1.5 times as high as combined exports to CIS and Baltics in 1995-99.

Table 5: Two statistical images of Bulgarian exports: total, EU-oriented, Belarus and CIS together with Baltic States (in millions of US dollars and percent)

\begin{tabular}{|l|rrrrr|}
\hline & 1995 & 1996 & 1997 & 1998 & 1999 \\
\hline Total exports (IMF) & 5,220 & 4,781 & 4,314 & 4,150 & 3,755 \\
\hline \hline to EU (IMF) & 2,013 & 1,913 & 1,942 & 2,137 & 2,035 \\
to Belarus (IMF) & 2,036 & 1,205 & 1,223 & 1,083 & 545 \\
\hline Total exports (BNB) & 4,967 & 4,689 & 4,809 & 4,193 & 4,006 \\
\hline \hline \multicolumn{1}{|c|}{ to CIS and Baltic states (BNP) } & 1,951 & 1,879 & 2,127 & 2,114 & 2,089 \\
\hline Difference total & 889 & 906 & 846 & 520 & 359 \\
Difference EU & $3 \%$ & $2 \%$ & $-10 \%$ & $-1 \%$ & $-6 \%$ \\
Difference Belarus vs. CIS/Baltics & $129 \%$ & $2 \%$ & $-9 \%$ & $1 \%$ & $-3 \%$ \\
\hline Memorandum: & & & & & \\
\hline \hline EU share (IMF) & $39 \%$ & $40 \%$ & $45 \%$ & $51 \%$ & $54 \%$ \\
EU share (BNB) & $39 \%$ & $40 \%$ & $44 \%$ & $50 \%$ & $52 \%$ \\
\hline
\end{tabular}

Source: Bulgarian National Bank official statistics and IMF Direction of Trade database.

From the point of view of this analysis, this is irrelevant who is right and who is wrong, as both sets of data coalesce in one important respect. The share of EU-15 in Bulgaria's total exports is roughly similar in both statistics and underlines features setting Bulgaria apart from other CEEC-9 economies in its geographical pattern of trade in the 1990s. In contrast to other CEEC-9, Bulgaria's shift towards the EU began to take place only in the late 1990's. Contrast this with the developments in direction of trade of neighboring Romania: the share of the EU was larger in Bulgarian than in Romanian total exports but only in 1993. While Romanian exporters moved quickly to EU markets, this did not happen in Bulgaria until 1998 (Table 6).

Table 6: Share of the EU-15 in Bulgaria's total exports and Romania's total exports in 1993-2003

\begin{tabular}{|l|ccccccccccc|}
\hline & 1993 & 1994 & 1995 & 1996 & 1997 & 1998 & 1999 & 2000 & 2001 & 2002 & 2003 \\
\hline \hline EU-15 in Bulgaria' s exports & $47 \%$ & $46 \%$ & $39 \%$ & $40 \%$ & $45 \%$ & $51 \%$ & $54 \%$ & $52 \%$ & $55 \%$ & $56 \%$ & $53 \%$ \\
EU-15 in Romania' s exports & $44 \%$ & $55 \%$ & $61 \%$ & $65 \%$ & $64 \%$ & $71 \%$ & $73 \%$ & $73 \%$ & $75 \%$ & $73 \%$ & $68 \%$ \\
\hline
\end{tabular}

Source: IMF Direction of Trade database.

Yet, had it not been for exports to the EU, the overall picture would have been bleaker, albeit exclusively during the 1997-99 crisis and the recovery phase that began in 2000. The fall in non-EU directed exports in 1997-99 was spectacular. In 1999 the value was almost 50 percent below its peak level in 1995. Huge fall in non-EU exports over 1997-99 rather than the explosion in EU-destined exports were responsible for the share of the EU to go above a 50 percent mark. Indeed, over 1996-99 EU-oriented grew on average at 2 percent per year, whereas non-EU exports fell at an annual rate of 11 percent. The total cumulative contraction in non-EU exports of 58 percent was, however, only partly offset by EU-oriented exports as the value of EU-directed exports also fell in both 1996 and 1999 cumulatively by around 10 percent. In 2003, the value of EU-directed exports was, however, 87 percent above the 1995 level that of other exports was merely six percent higher. Hence, the reorientation of Bulgaria's exports has occurred mainly at the expense of markets lost elsewhere.

Bulgaria's foreign trade statistics reported to the United Nations and available only since 1996, not only substantiate the above observations about Bulgaria's export performance in 199699 but they also point to the convergence of developments in 2000-03 with trends observed in other CEEC-9 economies. The 2000-03 phase witnessed stronger growth in EU-exports, with the average growth rate of 15 percent as compared with 9 percent for non-EU exports. 
Reorientation in Bulgaria's exports continued during the 2000-03 phase, with two important qualifications. First, in contrast to the preceding phase in 1996-99, which witnessed the collapse of exports to all markets except the EU, EFTA and aggregate market of CEEC-EU 2004 entrants, Bulgarian presence increased everywhere with a few notable exceptions-SEE-5 and CIS-12 (Table 7). While overall exports to SEE-5 stagnated, this was due solely to highly volatile exports to Serbia and Montenegro. Exports to Russia and Ukraine continued their downward trend, and the relevance of CIS markets has further declined. Their share fell from 19 percent in 1996 to 12 percent in 2000 and 3.6 percent in 2003.

Table 7: Direction and dynamics of Bulgaria's exports in 1996 and 1999-2003 (in millions of US dollars and percent)

\begin{tabular}{|c|c|c|c|c|c|c|c|c|c|c|c|c|}
\hline & \multicolumn{5}{|c|}{ (in millions of US dollars) } & \multicolumn{2}{|c|}{ Index 1999 Index 2000} & \multicolumn{5}{|c|}{ (in percent) } \\
\hline & 1996 & 2000 & 2001 & 2002 & 2003 & $1996=100$ & $2000=100$ & 1996 & 2000 & 2001 & 2002 & 2003 \\
\hline World & 4,890 & 4,822 & 5,114 & 5,749 & 7,540 & 80 & 156 & 100 & 100 & 100 & 100 & 100 \\
\hline EU-15, of which & 1,912 & 2,464 & 2,801 & 3,202 & 4,263 & 108 & 173 & 39.1 & 51.1 & 54.8 & 55.7 & 56.5 \\
\hline Germany & 442 & 435 & 488 & 549 & 812 & 88 & 187 & 9.0 & 9.0 & 9.5 & 9.5 & 10.8 \\
\hline Greece & 348 & 376 & 449 & 529 & 782 & 97 & 208 & 7.1 & 7.8 & 8.8 & 9.2 & 10.4 \\
\hline Italy & 493 & 684 & 765 & 886 & 1,057 & 112 & 155 & 10.1 & 14.2 & 15.0 & 15.4 & 14.0 \\
\hline CEEC-8, of which & 118 & 122 & 135 & 168 & 239 & 111 & 195 & 2.4 & 2.5 & 2.6 & 2.9 & 3.2 \\
\hline Czech Republic & 23 & 17 & 22 & 28 & 42 & 65 & 250 & 0.48 & 0.35 & 0.43 & 0.49 & 0.56 \\
\hline Estonia & 4 & 4 & 4 & 3 & 5 & 110 & 125 & 0.08 & 0.08 & 0.07 & 0.04 & 0.07 \\
\hline Hungary & 25 & 29 & 33 & 39 & 63 & 98 & 219 & 0.51 & 0.59 & 0.65 & 0.67 & 0.83 \\
\hline Latvia & 6 & 7 & 6 & 7 & 9 & 125 & 134 & 0.13 & 0.14 & 0.11 & 0.12 & 0.12 \\
\hline Lithuania & 13 & 6 & 8 & 8 & 11 & 48 & 183 & 0.26 & 0.12 & 0.15 & 0.14 & 0.14 \\
\hline Poland & 31 & 28 & 35 & 41 & 62 & 94 & 224 & 0.64 & 0.57 & 0.68 & 0.72 & 0.82 \\
\hline Slovak Republic & 11 & 6 & 9 & 18 & 18 & 69 & 320 & 0.24 & 0.12 & 0.17 & 0.31 & 0.24 \\
\hline Slovenia & 4 & 27 & 20 & 25 & 30 & 877 & 110 & 0.08 & 0.56 & 0.39 & 0.43 & 0.39 \\
\hline EFTA & 46 & 55 & 65 & 104 & 55 & 118 & 235 & 0.94 & 1.13 & 1.27 & 1.82 & 1.70 \\
\hline Romania & 75 & 88 & 129 & 160 & 230 & 73 & 261 & 1.54 & 1.82 & 2.52 & 2.78 & 3.05 \\
\hline Turkey & 384 & 495 & 413 & 536 & 690 & 74 & 139 & 7.86 & 10.26 & 8.07 & 9.32 & 9.15 \\
\hline $\begin{array}{l}\text { Pan-European (all } \\
\text { above) }\end{array}$ & 2,535 & 3,224 & 3,543 & 4,170 & 5,477 & 114 & 170 & 51.8 & 66.9 & 69.3 & 72.5 & 72.6 \\
\hline SEE-5, of which & 530 & 540 & 385 & 384 & 508 & 63 & 94 & 10.83 & 11.20 & 7.53 & 6.68 & 6.74 \\
\hline Albania & 43 & 24 & 27 & 40 & 30 & 75 & 125 & 0.88 & 0.50 & 0.53 & 0.70 & 0.40 \\
\hline $\mathrm{BiH}$ & 3 & 9 & 10 & 11 & 10 & 300 & 108 & 0.06 & 0.19 & 0.20 & 0.19 & 0.13 \\
\hline Croatia & 13 & 5 & 6 & 16 & 44 & 45 & 944 & 0.27 & 0.10 & 0.11 & 0.27 & 0.59 \\
\hline Macedonia & 149 & 110 & 113 & 126 & 155 & 70 & 141 & 3.04 & 2.28 & 2.22 & 2.18 & 2.05 \\
\hline Moldova & 91 & 16 & 19 & 17 & 21 & 21 & 131 & 1.86 & 0.33 & 0.38 & 0.30 & 0.27 \\
\hline Serbia \& Mont & 231 & 376 & 209 & 174 & 249 & 71 & 66 & 4.73 & 7.80 & 4.09 & 3.03 & 3.30 \\
\hline CIS (11), of which & 927 & 458 & 520 & 242 & 268 & 55 & 59 & 19.0 & 9.5 & 10.2 & 4.2 & 3.6 \\
\hline Russia & 480 & 118 & 120 & 92 & 105 & 39 & 89 & 9.8 & 2.5 & 2.3 & 1.6 & 1.4 \\
\hline Ukraine & 166 & 240 & 300 & 53 & 59 & 148 & 25 & 3.4 & 5.0 & 5.9 & 0.9 & 0.8 \\
\hline ROW & 863 & 568 & 634 & 910 & 1,239 & 53 & 218 & 17.6 & 11.8 & 12.4 & 15.8 & 16.4 \\
\hline
\end{tabular}

Source: Derived from UN COMTRADE database as reported by Bulgaria.

Second, there has been a significant increase in Bulgarian supplies to markets of Central European countries, which once shared with Bulgaria membership in the long defunct CMEA, and now-except Romania-are members of the EU. Bulgarian exports to EU-2004 entrants almost doubled between 2000 and 2003 and to Romania almost tripled. Their aggregate share in Bulgaria's exports rose from 4 percent in 1996 to 6 percent in 2002.

In all, the share of pan-European countries in Bulgaria's exports increased from 53 percent in 1996 to 68 percent in 2000 and further expanded each year to reach 74 percent in 2003.

Similar trends, albeit less pronounced, were observable on the import side. First, Bulgaria's imports shifted towards the EU but only since 1997. Its share in Bulgaria's total imports grew from 35 percent in 1996 to 44 percent in 2000 to 50 percent in 2001 and remained at this level in 2002-03. While among EU members, Italy has been the major market for Bulgarian exports, Germany has been Bulgaria's major supplier accounting for around 14 percent of total imports in 2000-03 (Table 8). In a similar vein, Bulgaria's imports have also shifted 
towards other pan-European partners. The share of CEEC-8 increased from 3 percent in 1996 to 6 percent in 2003. So did the shares of Romania and Turkey. The latter displayed the strongest growth with its share in Bulgaria's imports rising from 2 percent in 1996 to 4 percent in 2001 and 6 percent in 2003.

Table 8: Direction and dynamics of Bulgaria's imports in 1996 and 1999-2003 (in millions of US dollars and percent)

\begin{tabular}{|c|c|c|c|c|c|c|c|c|c|c|c|c|}
\hline & \multicolumn{5}{|c|}{ (in millions of US dollars) } & \multicolumn{2}{|c|}{ Index 1999 Index 2003} & \multicolumn{5}{|c|}{ (in percent) } \\
\hline & 1996 & 2000 & 2001 & 2002 & 2003 & $1996=100$ & $100=2000$ & 1996 & 2000 & 2001 & 2002 & 2003 \\
\hline World & 5,074 & 6,505 & 7,278 & 7,987 & 10,901 & 107 & 168 & 100 & 100 & 100 & 100 & 100 \\
\hline EU-15, of which & 1,780 & 2,864 & 3,592 & 4,015 & 5,406 & 148 & 189 & 35.1 & 44.0 & 49.4 & 50.3 & 49.6 \\
\hline Germany & 575 & 903 & 1,112 & 1,139 & 1,555 & 141 & 172 & 11.3 & 13.9 & 15.3 & 14.3 & 14.3 \\
\hline Greece & 196 & 317 & 412 & 482 & 725 & 156 & 229 & 3.9 & 4.9 & 5.7 & 6.0 & 6.7 \\
\hline Italy & 319 & 550 & 699 & 906 & 1,115 & 144 & 203 & 6.3 & 8.5 & 9.6 & 11.3 & 10.2 \\
\hline CEEC-8 of which & 166 & 341 & 383 & 424 & 620 & 167 & 182 & 3.3 & 5.2 & 5.3 & 5.3 & 5.7 \\
\hline " Czech Republic & 66 & $\bar{~} 118$ & 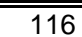 & $\overline{\overline{124}}$ & 177 & 149 & $\overline{c 150}$ & 1.3 & 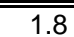 & 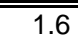 & 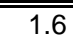 & 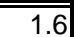 \\
\hline Estonia & 0 & 0 & 0 & 0 & 1 & 58 & 497 & 0.0 & 0.0 & 0.0 & 0.0 & 0.0 \\
\hline Hungary & 33 & 62 & 80 & 102 & 135 & 148 & 219 & 0.7 & 0.9 & 1.1 & 1.3 & 1.2 \\
\hline Latvia & 1 & 1 & 1 & 1 & 2 & 29 & 281 & 0.0 & 0.0 & 0.0 & 0.0 & 0.0 \\
\hline Lithuania & 4 & 3 & 3 & 6 & 13 & 82 & 520 & 0.1 & 0.0 & 0.0 & 0.1 & 0.1 \\
\hline Poland & 33 & 90 & 107 & 100 & 153 & 220 & 171 & 0.7 & 1.4 & 1.5 & 1.3 & 1.4 \\
\hline Slovak Republic & 19 & 41 & 38 & 45 & 72 & 159 & 175 & 0.4 & 0.6 & 0.5 & 0.6 & 0.7 \\
\hline Slovenia & 8 & 27 & 37 & 46 & 67 & 273 & 244 & 0.2 & 0.4 & 0.5 & 0.6 & 0.6 \\
\hline EFTA & 91 & 89 & 91 & 109 & 164 & 97 & 183 & 1.8 & 1.5 & 1.4 & 1.2 & 1.3 \\
\hline Romania & 70 & 232 & 173 & 164 & 262 & 101 & 113 & 1.4 & 3.6 & 2.4 & 2.0 & 2.4 \\
\hline Turkey & 96 & 215 & 274 & 394 & 667 & 171 & 311 & 1.9 & 3.3 & 3.8 & 4.9 & 6.1 \\
\hline SEE-5, of which & 105 & 55 & 46 & 61 & 97 & 44 & 177 & 2.1 & 0.8 & 0.6 & 0.8 & 0.9 \\
\hline Albania & 0 & $\overline{0}$ & $\overline{0}$ & $\overline{0}$ & 0 & 28 & 340 & 0.0 & 0.0 & 0.0 & 0.0 & 0.0 \\
\hline $\mathrm{BiH}$ & 0 & 0 & 0 & 1 & 1 & 113 & 277 & 0.0 & 0.0 & 0.0 & 0.0 & 0.0 \\
\hline Croatia & 5 & 4 & 2 & 14 & 31 & 42 & 836 & 0.1 & 0.1 & 0.0 & 0.2 & 0.3 \\
\hline Macedonia & 32 & 26 & 20 & 18 & 24 & 78 & 93 & 0.6 & 0.4 & 0.3 & 0.2 & 0.2 \\
\hline Moldova & 12 & 2 & 3 & 4 & 7 & 31 & 302 & 0.2 & 0.0 & 0.0 & 0.0 & 0.1 \\
\hline Serbia \& Mont & 56 & 23 & 21 & 24 & 34 & 27 & 151 & 1.1 & 0.3 & 0.3 & 0.3 & 0.3 \\
\hline CIS (11) of which & 1,860 & 1,960 & 1,818 & 1,480 & 2,017 & 75 & 103 & 36.7 & 30.1 & 25.0 & 18.5 & 18.5 \\
\hline Russia & 1,694 & 1,585 & 1,457 & 1,171 & 1,370 & 66 & 86 & 33.4 & 24.4 & 20.0 & 14.7 & 12.6 \\
\hline Ukraine & 122 & 335 & 323 & 248 & 430 & 195 & 128 & 2.4 & 5.2 & 4.4 & 3.1 & 3.9 \\
\hline ROW & 1,015 & 804 & 949 & 1,401 & 1,792 & 78 & 223 & 20.0 & 12.4 & 13.0 & 17.5 & 16.4 \\
\hline
\end{tabular}

Source: Derived from UN COMTRADE database as reported by Bulgaria.

Last but not, significance of imports from CIS countries has continued similar downward path as in Bulgaria's exports. Their aggregate share in Bulgaria's imports fell from 30 percent in 2000 to 19 percent in 2002-03.

To sum up, Bulgaria's geographical trade pattern has indeed displayed characteristics distinctive from other CEEC-9 economies. But this was only the case until around the financial crisis in 1996-97. Bulgaria's trade peculiarity, not only confined to directions of trade but also revealed in Bulgaria's factor content intensity of exports, came to an end in the period following the adoption and implementation of stabilization-cum-transformation program in 1997. While the share of the EU-15 in Bulgaria's foreign trade remains below the levels of other CEEC-9 economies, the share of trade with pan-European partners is at a similar level. The convergence to patterns of these countries occurred only during the current expansionary phase that began in 2000.

\section{Dynamics of EU-destined exports in regional perspective}

Since changes in the exchange rate of the US dollar vis-à-vis Euro may distort dynamics of exports even examined in a comparative perspective, Table 9 and Figure 3 present the evolution of shares of Bulgaria in EU external imports against those of its regional partnersCEEC-8, Romania and SEE-5. The data corroborate earlier observations about non-sustainability 
of Bulgaria's EU-oriented export growth during the initial stages of transition; its overall lackluster performances through the 1990s and turn around in the early 2000s. Bulgaria increased its presence in EU markets in 1993-96 roughly to the same extent as CEEC-8, albeit significantly less than Romania. Indeed, until 1995 Bulgaria's performance in these markets did not diverge from that of CEEC-8 or Romania. ${ }^{10}$ However, in contrast to them, its performance was highly volatile indicating the persistent status of a marginal supplier (Figure 3).

Table 9: Share of Bulgaria, CEEC-8 and SEE-5 in EU-15 external imports in 1993, 1996-97, 2000 and 2003 (in percent)

\begin{tabular}{|c|c|c|c|c|c|c|c|c|c|c|}
\hline & & & & & & $\begin{array}{c}\text { Index, } \\
1996\end{array}$ & $\begin{array}{c}\text { Index } \\
1999\end{array}$ & $\begin{array}{l}\text { Index, } \\
2003\end{array}$ & $\begin{array}{c}\text { Index, } \\
2003\end{array}$ & Change \\
\hline & 1993 & 1996 & 1997 & 2000 & 2003 & $1993=100$ & $1997=100$ & $2000=100$ & $1993=100$ & in 2003 \\
\hline Bulgaria & 0.22 & 0.29 & 0.31 & 0.29 & 0.37 & 132 & 90 & 128 & 168 & 5.7 \\
\hline CEEC-8 & 5.29 & 7.12 & 7.40 & 8.34 & 11.1 & 135 & 115 & 133 & 210 & 8.6 \\
\hline Romania & 0.37 & 0.61 & 0.66 & 0.74 & 1.10 & 165 & 111 & 149 & 297 & 7.8 \\
\hline SEE-5 & 0.51 & 0.49 & 0.53 & 0.42 & 0.54 & 96 & 85 & 129 & 106 & 8.0 \\
\hline
\end{tabular}

Source: Based on EU as reporter from UN COMTRADE Statistics.

Figure 3: Annual change in shares in EU external imports in 1993-2003 $(1999=100)$

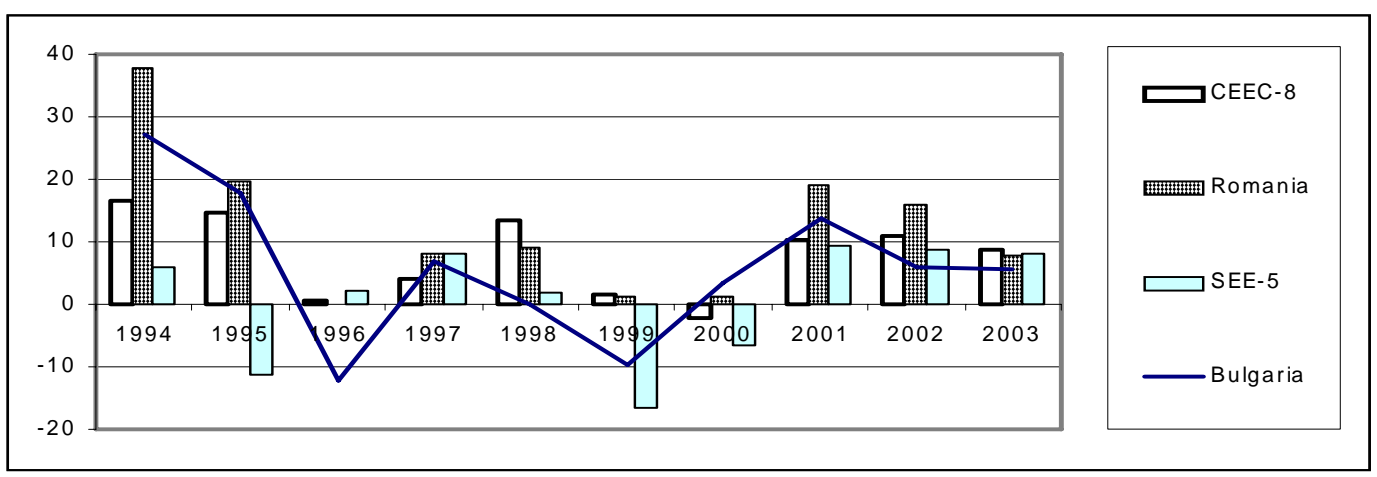

Source: As in Table 9.

While both CEEC-8 and Romania expanded their presence in EU markets in the 1990s, Bulgaria's share in EU external imports stagnated. Consider that in 1999 its share was exactly the same as that in 1994. CEEC-8 and Romania's shares were respectively 38 percent and 43 percent higher in 1999 than in 1994. Hence, the 1996-97 crisis, preceded by several years of policies destroying Bulgaria's industrial base, exacted a heavy toll on Bulgaria's export performance in EU markets.

The improvement in export performance during the current expansionary phase so far has not been sufficient to compensate for the losses in Bulgaria's competitive position experienced in the 1996-99 period and triggered by half decade of gross economic mismanagement. In 1996 Bulgaria's share in EU imports contracted 12 percent and it fell again in 1999 by 10 percent. Since 1999 Bulgaria has expanded its presence in EU markets roughly at the same pace as on average the SEE-5 economies and slightly below the growth in the share of the CEEC-8 in EU imports. Yet, its share in EU external imports was in 2003 only 12 percent above its peak level in 1995 while that of CEEC-8 was 57 percent and Romania's 80 percent in the same period.

${ }^{10}$ During the 1989-95 phase Bulgaria recorded an average annual growth rate of its EU destined exports of 21 percent and its share in EU external imports expanded on average at 14 percent. This compares very favorably to corresponding averages for Czech Republic, Hungary and Poland. Only the Czech Republic registered a faster growth of 23 percent and 16 percent. The differences emerged in 1996-99 (Annex Table $3)$. 
Bulgaria outperformed only SEE-5 economies, not a great achievement considering that civil wars and violence affected most of them. Their aggregate share in EU imports in 2003 stood at the same level as almost a decade ago in 1994. In terms of cumulative annual changes in growth rates in 1994-2003, Romania scored 120 percentage points, CEEC-8 scored 79 points, Bulgaria 59 points and SEE-5 only 10 percentage points.

\section{E. Concluding observations}

The period following launching of the stabilization-cum-transformation program in 1997 has three characteristics. First, it has witnessed continuation of an unavoidable shift away-which began in 1999-from the reliance on Eastern markets excluding former Central European members of the EU. The significance of the latter in Bulgaria's trade has been on the increase. Second, exports of goods rather than services have been the driver of export expansion. The share of services in total exports slightly contracted over 1999-2003, although this might be due to their systematic underreporting in foreign trade statistics all over the world. Third, considering the depth of contraction during the crisis phase, the rebound in exports was relatively modest. It appears that improved, duty-free access to markets for industrial products taking around 80 percent of Bulgarian exports of goods is yet to produce tangible positive effects. This is the price that the Bulgarian economy continues to be paying for flagrant economic mismanagement in 1990-96.

\section{Commodity composition of trade and the degree of processing}

Questions addressed in this section boil down to the following: What do the changes in import demand tell us about the pace of industrial restructuring? What do the changes in exports depending on the degree of processing embodied in exported products tell us about Bulgaria's industrial capacities? What characteristics do new star performers embody in terms of technology and the degree of processing?

\section{A. Changes in the composition of imports}

The composition of imports in terms of end-use product categories sheds light on changes in the domestic demand for various goods depending on the extent of their processing. Thus, for instance, the increase in imports of machinery usually points to the ongoing industrial restructuring effort. In a similar vein, the increase in automobiles and parts may be in part related to the emergence of firms specializing in production of parts or automobiles. In contrast to machinery, this would call for in-depth investigation of imports.

Table 10 provides information on Bulgaria's imports by end-use product categories from the world, pan-European partners (EU-25, EFTA, Romania and Turkey) and ROW together with their composition from each source. It also provides information on the change in the value of imports between 2003 and 1998. The reason for the selection of 1998 as a base year is that 1998 market the first year that imports rebounded as well as it was the initial period for Bulgaria's second attempt to move swiftly to an economy based on competitive markets. A cursory examination leads to the following observations: First, other consumer goods, or final manufactures, now account for more than half of Bulgaria's total imports in large part due to the significant decline in imports of fuels. Their imports in terms of value stood at 44 percent of their level in 1998. Other consumer goods and automobiles and part recorded the largest increases between 1998 and 2003.

Second, there are two indications of an ongoing industrial revival—continuing expansion of imports of industrial raw materials, which increased in line with total import demand growth, and the increase in the share of machinery in total imports. The value of these almost tripled between 1998 and 2003 and was 89 percent higher than in 2000. 
Table 10: Bulgaria's imports by end-use product categories: total pan-European partners and ROW in 1996 and 2000--2003(in millions of US dollars and percent)

\begin{tabular}{|c|c|c|c|c|c|c|c|c|c|c|c|}
\hline \multirow[b]{2}{*}{ World } & \multicolumn{5}{|c|}{ Import Value (in millions of US dollars) } & \multicolumn{5}{|c|}{ Share in percent } & \multirow{2}{*}{\begin{tabular}{|l|} 
Index $2003^{11}$ \\
$2000=100$ \\
\end{tabular}} \\
\hline & 1996 & 2000 & 2001 & 2002 & 2003 & 1996 & 2000 & 2001 & 2002 & 2003 & \\
\hline Agricultural Food \& Feeds & 516 & 422 & 482 & 557 & 732 & 10.2 & $\overline{6.5}$ & 6.6 & $\overline{7.0}$ & 6.7 & 173 \\
\hline Industrial Raw Materials & 225 & 368 & 410 & 364 & 592 & 4.4 & 5.7 & 5.6 & 4.6 & 5.4 & 161 \\
\hline Machinery, excl Automobiles & 653 & 1,172 & 1,420 & 1,554 & 2,220 & 12.9 & 18.0 & 19.5 & 19.5 & 20.4 & 189 \\
\hline Automobiles \& Parts & 155 & 446 & 576 & 645 & 900 & 3.1 & 6.9 & 7.9 & 8.1 & 8.3 & 202 \\
\hline Other Consumer Goods & 1,809 & 2,412 & 4,021 & 4,594 & 6,023 & 35.7 & 37.1 & 55.2 & 57.5 & 55.3 & 250 \\
\hline Fuels & 1,716 & 1,683 & 368 & 274 & 434 & 33.8 & 25.9 & 5.1 & 3.4 & 4.0 & 26 \\
\hline All Goods & 5,074 & 6,505 & 7,278 & 7,987 & 10,901 & 100 & 100 & 100 & 100 & 100 & 168 \\
\hline \multicolumn{12}{|l|}{ Pan-European economies } \\
\hline Agricultural Food \& Feeds & 183 & 228 & 264 & 314 & 413 & 8.6 & 6 & 6.1 & 6.4 & $\begin{array}{ll}6.0 \\
\end{array}$ & 181 \\
\hline Industrial Raw Materials & 56 & 108 & 107 & 117 & 183 & 2.6 & 3.1 & 2.5 & 2.4 & 2.7 & 170 \\
\hline Machinery, excl Automobiles & 474 & 833 & 1,068 & 1,135 & 1,600 & 22.3 & 23.7 & 24.6 & 23.0 & 23.4 & 192 \\
\hline Automobiles \& Parts & 117 & 400 & 529 & 590 & 810 & 5.5 & 11.4 & 12.2 & 11.9 & 11.9 & 202 \\
\hline Other Consumer Goods & 1,281 & 1,882 & 2,310 & 2,730 & 3,747 & 60.2 & 53.7 & 53.2 & 55.2 & 54.9 & 199 \\
\hline Fuels & 19 & 57 & 61 & 57 & 77 & 0.9 & 1.6 & 1.4 & 1.2 & 1.1 & 135 \\
\hline All Goods & 2,129 & 3,508 & 4,339 & 4,943 & 6,829 & 100 & 100 & 100 & 100 & 100 & 195 \\
\hline \multicolumn{12}{|l|}{ Of which the EU-15 } \\
\hline Agricultural Food \& Feeds & 153 & 179 & 204 & $\overline{234}$ & 295 & $\overline{8.6}$ & 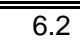 & 5.7 & 5.8 & 5.5 & 165 \\
\hline Industrial Raw Materials & 34 & 74 & 69 & 80 & 99 & 1.9 & 2.6 & 1.9 & 2 & 1.8 & 134 \\
\hline Machinery, excl Automobiles & 407 & 695 & 920 & 948 & 1,288 & 22.9 & 24.3 & 25.6 & 23.6 & 23.8 & 185 \\
\hline Automobiles \& Parts & 105 & 376 & 501 & 557 & 754 & 5.9 & 13.1 & 13.9 & 13.9 & 14.0 & 201 \\
\hline Other Consumer Goods & 1,063 & 1,503 & 1,856 & 2,146 & 2,900 & 59.7 & 52.5 & 51.7 & 53.4 & 53.6 & 193 \\
\hline Fuels & 18 & 37 & 43 & 51 & 70 & 1 & 1.3 & 1.2 & 1.3 & 1.3 & 189 \\
\hline All Goods & 1,780 & 2,864 & 3,592 & 4,015 & 5,406 & 100 & 100 & 100 & 100 & 100 & 189 \\
\hline \multicolumn{12}{|l|}{ ROW } \\
\hline Agricultural Food \& Feeds & 333 & 195 & 218 & 243 & 319 & 11.3 & 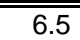 & 7.4 & 8.0 & 7.8 & 164 \\
\hline Industrial Raw Materials & 169 & 260 & 303 & 248 & 409 & 5.7 & 8.7 & 10.3 & 8.1 & 10.0 & 157 \\
\hline Machinery, excl. Automobiles & 179 & 339 & 353 & 419 & 621 & 6.1 & 11.3 & 12.0 & 13.8 & 15.2 & 183 \\
\hline Automobiles \& Parts & 38 & 46 & 47 & 55 & 90 & 1.3 & 1.5 & 1.6 & 1.8 & 2.2 & 195 \\
\hline Other Consumer Goods & 528 & 530 & 1,711 & 1,864 & 2,276 & 17.9 & 17.7 & 58.2 & 61.2 & 55.9 & 430 \\
\hline Fuels & 1,697 & 1,626 & 308 & 216 & 357 & 57.6 & 54.3 & 10.5 & 7.1 & 8.8 & 22 \\
\hline All Goods & 2,945 & 2,996 & 2,939 & 3,044 & 4,072 & 100 & 100 & 100 & 100 & 100 & 136 \\
\hline $\begin{array}{l}\text { Memorandum: Share of } \\
\text { manufactures in total imports }\end{array}$ & $52 \%$ & $62 \%$ & $83 \%$ & $85 \%$ & $84 \%$ & & & & & & \\
\hline
\end{tabular}

Note: The end-use categories are defined as Agricultural Food \& Feeds (SITC 0+1+2+4-27-28); Industrial Raw Materials (SITC 27+28+68); Machinery, excluding automobiles (SITC 7-78), Automobiles \& Parts (SITC 78), Other Consumer Goods (SITC 5+6+8+9-68); Fuels (SITC 3); and All Goods (0 to 9).

${ }_{11}$ Index 2003 over 2000 refers to values of imports.

Source: Based on Bulgaria's reporting to UN COMTRADE Statistics.

Third, the compositions of imports by end-use from pan-European countries and ROW differ pointing towards Bulgaria's growing integration into Pan-European markets. Imports from the pan-European free trade area are much more processed, with fuels, agricultural foods and feeds and industrial raw materials accounting for less than ten percent. This share in Bulgaria's imports from ROW is more than twice as large. Moreover, this gap appears to be growing. Although ROW suppliers seem to have been retained their competitive edge in Bulgaria's markets for machinery and capital equipment excluding transportation, ${ }^{11}$ they lost their share in Bulgaria's imports of automotive products; it fell from around 20 percent in 1996-99 to 10 percent in 2003.

While suppliers from the EU-15 still tower above others, their dominant position has slightly weakened in all product categories except in automobiles and parts and agricultural foods and feeds. Their respective shares in Bulgaria's imports of these products increased from 65 percent and 39 percent in 1998 to 84 percent and 40 percent in 2003.

\footnotetext{
11 Their share Bulgaria’s imports of these products have been relatively stable at around 25-30 percent since 1996.
} 
The shift towards the EU-15 or more generally pan-European countries as sources of imports that began to take place in the post-1996 crisis environment appears to have been related with first signs of industrial restructuring. Privatization and improvements in investment climate have prompted businesses to restructure and modernize their industrial base. Consider the following. First, the share of manufactures in Bulgaria's exports has significantly increased. It grew from 52 percent in 1996 to 62 percent in 2000 and 84 percent in 2003 (Table 10 above). Furthermore, the weight of traditional inputs in Bulgaria's imports has continued falling.

Second, this has been accompanied by the shift towards imports of manufactured products with higher technology content. Table 11 tabulates Bulgaria's imports of manufactures from Pan-European free trade area for industrial products filtered in terms of technology. We use a simple taxonomy developed by Landesman and Stehrer (2003), modified in two respects: First, we restrict its application to manufactured products identified in Standard International Trade Classification as containing items 5 through 8 minus 68. Foods and feeds as well as other traditional production inputs are thus not taken into account. Second, we merge together two categories-low technology and labor intensive activities and resource intensive activitiesunder a single heading of low technology products. In consequence, the taxonomy is limited to low technology products and medium to high tech products. The former category includes textiles and clothing, wood products, most chemicals, tires, etc. The latter include machinery and equipment, transport equipment, and electrical and optical equipment, pharmaceuticals, etc. The results presented in Table 11 show that medium to high technology products, accounting for around 60 percent of total manufactured imports from the Pan-European area, have expanded faster since 1997 than imports of low technology products.

Table 11: "Technology content" of Bulgaria's manufactured imports from Pan-European area in 19962003 (in millions of US dollars and percent)

\begin{tabular}{|c|c|c|c|c|c|c|c|c|c|c|}
\hline & 1996 & 1997 & 1998 & 1999 & 2000 & 2001 & 2002 & 2003 & \multirow{2}{*}{\multicolumn{2}{|c|}{\begin{tabular}{|cc} 
Index, 1999 Index, 2003 \\
$1997=100 \quad 2000=100$
\end{tabular}}} \\
\hline & \multicolumn{8}{|c|}{ (in millions of US dollars) } & & \\
\hline \multirow{4}{*}{$\begin{array}{l}\text { Low-technology products } \\
\text { Medium to high tech products } \\
\text { Total }\end{array}$} & 773 & 820 & 865 & 988 & $\overline{11,184}$ & 1,413 & 1,593 & 2,243 & 120 & 189 \\
\hline & 1,128 & 1,096 & 1,452 & 1,845 & 1,962 & 2,526 & 2,830 & 3,859 & 168 & 197 \\
\hline & 1,902 & 1,917 & 2,316 & 2,834 & 3,146 & 3,940 & 4,422 & 6,102 & 148 & 194 \\
\hline & \multicolumn{8}{|c|}{ (in terms of percent) } & & \\
\hline Low-technology products & 41 & 43 & 37 & 35 & 38 & 36 & 36 & 37 & 81 & 98 \\
\hline Medium to high tech products & 59 & 57 & 63 & 65 & 62 & 64 & 64 & 63 & 114 & 101 \\
\hline \multicolumn{9}{|c|}{ Memorandum: Share of Pan-European imports } & & \\
\hline $\begin{array}{l}\text { in Bulgaria's manufactured } \\
\text { imports }\end{array}$ & 78 & 78 & 77 & 81 & 82 & 83 & 83 & 82 & 104 & 100 \\
\hline in Bulgaria's total imports & 23 & 22 & 34 & 47 & 41 & 49 & 49 & 51 & 212 & 126 \\
\hline
\end{tabular}

Source: Own calculations based on Bulgaria's reporting to UN COMTRADE database.

Another indication of some progress in industrial restructuring is the improvement in Bulgaria's net exports of machinery between 1999 and 2003. Exports of machinery in terms of their imports increased from 38 percent in 2001 to 42 percent in 2003 (Table 12). Taking into account that the value of these imports in 2003 was 83 percent above their 2000 level, this strikes one as quite an impressive export performance. It appears that the "EU-15-connection" has been crucial not only as a supplier but also as a buyer accounting for more than 50 percent of turnover in machinery and automobiles and parts. Consider that both exports of machinery and automobiles and parts grew fastest in terms of their imports from the EU. This was not because of falling imports from the EU as these increased in 2000-03 by 105 percent (machinery) and 85 percent (automobiles and parts). 
Table 12: Exports of end-use products in terms of their imports in 1996-2003 (in percent)

\begin{tabular}{|l|rrrrrrrr|}
\hline & \multicolumn{7}{|c|}{ Export in percent of imports } \\
\hline & 1996 & 1997 & 1998 & 1999 & 2000 & 2001 & 2002 & 2003 \\
\hline \hline Agricultural Food \& Feeds & 199 & 147 & 167 & 180 & 143 & 127 & 149 & 127 \\
Industrial Raw Materials & 210 & 187 & 122 & 143 & 166 & 132 & 154 & 131 \\
Machinery, excluding Automobiles & 87 & 77 & 61 & 35 & 38 & 38 & 44 & 42 \\
Automobiles \& Parts & 24 & 17 & 8.8 & 9.3 & 4.3 & 3.7 & 5.0 & 4.8 \\
Other Consumer Goods & 136 & 149 & 113 & 101 & 107 & 73 & 72 & 73 \\
Fuels & 19 & 25 & 15 & 25 & 33 & 125 & 126 & 101 \\
All Goods & 96 & 100 & 86 & 73 & 74 & 70 & 72 & 69 \\
\hline
\end{tabular}

Source: Based on Bulgaria's reporting from UN COMTRADE Statistics.

\section{B. Degree of processing embodied in EU-oriented exports: end-use product categories}

The composition of exports in terms of end-use product categories sheds light on changes in the extent of processing embodied in exported products as well as to differences in drivers of growth in both 1996-99 and 2000-03 phases in terms of the level of processing embodied in exports. Table 13 presents the structure of Bulgaria's EU-15-oriented exports in these categories.

Table 13: EU-oriented exports by end-use product categories in 1996-2003(in millions of US dollars): composition and share in EU imports (in percent)

\begin{tabular}{|c|c|c|c|c|c|c|c|c|c|c|}
\hline & \multicolumn{8}{|c|}{ Exports to EU (in million of US dollars) } & \multicolumn{2}{|c|}{ Average growth rate } \\
\hline & 1996 & 1997 & 1998 & 1999 & 2000 & 2001 & 2002 & 2003 & $1996-99$ & $2000-03$ \\
\hline Food \& Feed $(0+1+2+4-27-28)$ & 359 & 354 & 346 & 334 & 256 & 289 & 428 & 404 & -1.8 & 12.1 \\
\hline $5(27+28+68)$ & 231 & 248 & 286 & 297 & 548 & 368 & 380 & 538 & 6.5 & -0.5 \\
\hline Machinery, excluding auto (7-78) & 200 & 176 & 217 & 243 & 250 & 283 & 369 & 525 & 5.0 & 20.4 \\
\hline Automobiles \& Parts (78) & 24 & 9 & 12 & 10 & 11 & 14 & 22 & 29 & -20.0 & 28.7 \\
\hline Consumer Goods (5+6+8+9-68) & 1,330 & 1,541 & 1,626 & 1,460 & 1,693 & 2,029 & 1,952 & 2,543 & 2.4 & 10.7 \\
\hline of which: textiles (65) & 73 & 80 & 88 & 68 & 64 & 86 & 121 & 156 & -1.7 & 25.1 \\
\hline clothin & 398 & 477 & 598 & 629 & 729 & 911 & 872 & 1,154 & 12.1 & 12.2 \\
\hline footwear (623 & 103 & 128 & 121 & 111 & 116 & 161 & 172 & 222 & 1.8 & 17.7 \\
\hline Fuels (3) & 33 & 46 & 31 & 16 & 59 & 117 & 46 & 151 & -16.4 & 26.3 \\
\hline \multirow[t]{3}{*}{ All Goods (0 to 9$)$} & 2,204 & 2,410 & 2,539 & 2,378 & 2,840 & 3,120 & 3,290 & 4,272 & 1.9 & 10.7 \\
\hline & \multicolumn{8}{|c|}{ Composition of exports (in percent) } & \multicolumn{2}{|c|}{ Index, 1999 Index, 2003} \\
\hline & 1996 & 1997 & 1998 & 1999 & 2000 & 2001 & 2002 & 2003 & $1996=100$ & $2000=100$ \\
\hline 000 & 16.3 & 14.7 & 13.6 & 14.0 & 9.0 & 9.3 & 13.0 & 9.5 & 86 & 105 \\
\hline Indus & 10.5 & 10.3 & 11.3 & 12.5 & 19.3 & 11.8 & 11.6 & 12.6 & 119 & 65 \\
\hline uto $(7-78)$ & 9.1 & 7.3 & 8.6 & 10.2 & 8.8 & 9.1 & 11.2 & 12.3 & 113 & 140 \\
\hline 8) & 1.1 & 0.4 & 0.5 & 0.4 & 0.4 & 0.5 & 0.7 & 0.7 & 38 & 183 \\
\hline Consumer Goods (5 & 60.4 & 63.9 & 64.0 & 61.4 & 59.6 & 65.0 & 59.3 & 59.5 & 102 & 100 \\
\hline of which: textile & 3.3 & 3.3 & 3.5 & 2.9 & 2.2 & 2.8 & 3.7 & 3.6 & 86 & 163 \\
\hline clothin & 18.1 & 19.8 & 23.5 & 26.4 & 25.7 & 29.2 & 26.5 & 27.0 & 146 & 105 \\
\hline footwear (623 & 4.7 & 5.3 & 4.8 & 4.6 & 4.1 & 5.2 & 5.2 & 5.2 & 99 & 128 \\
\hline \multirow[t]{3}{*}{ Fuels (3) } & 1.5 & 1.9 & 1.2 & 0.7 & 2.1 & 3.7 & 1.4 & 3.5 & 45 & 169 \\
\hline & \multicolumn{8}{|c|}{ Share in EU imports (in percent) } & \multicolumn{2}{|c|}{ Average growth rate } \\
\hline & 1996 & 1997 & 1998 & 1999 & 2000 & 2001 & 2002 & 2003 & $1996-99$ & $2000-03$ \\
\hline $27-28)$ & 0.41 & 0.41 & 0.40 & 0.41 & 0.32 & 0.36 & 0.52 & 0.42 & 0.3 & 7.0 \\
\hline $27+28+68)$ & 0.78 & 0.79 & 0.88 & 0.99 & 1.54 & 1.13 & 1.24 & 1.49 & 6.2 & -0.8 \\
\hline xcluding auto (7-78) & 0.09 & 0.08 & 0.09 & 0.09 & 0.08 & 0.10 & 0.14 & 0.16 & -0.6 & 18.4 \\
\hline Auto & 0.07 & 0.03 & 0.03 & 0.02 & 0.02 & 0.03 & 0.04 & 0.04 & -27.6 & 17.5 \\
\hline Consumer Goods $(5+6+8+9-68)$ & 0.50 & 0.55 & 0.55 & 0.49 & 0.53 & 0.63 & 0.58 & 0.64 & -0.5 & 4.7 \\
\hline of which: textiles (65) & 0.42 & 0.43 & 0.45 & 0.37 & 0.34 & 0.48 & 0.67 & 0.76 & -2.6 & 21.8 \\
\hline clothing & 0.87 & 1.00 & 1.20 & 1.25 & 1.44 & 1.74 & 1.58 & 1.74 & 9.4 & 4.9 \\
\hline footwear (623 and 85) & 1.28 & 1.45 & 1.40 & 1.22 & 1.22 & 1.55 & 1.56 & 1.69 & -1.2 & 8.6 \\
\hline Fuels (3) & 0.14 & 0.19 & 0.18 & 0.08 & 0.20 & 0.36 & 0.24 & 0.37 & -12.9 & 16.4 \\
\hline All Goods (0 to 9) & 0.29 & 0.31 & 0.31 & 0.28 & 0.29 & 0.33 & 0.35 & 0.37 & -0.9 & 6.0 \\
\hline
\end{tabular}

Source: Based on EU Data from UN COMTRADE Statistics.

Data tabulated in Table 13 point to an increase in the level of processing embodied in exports during the current phase, as captured by changes in the weight of foods and feeds together with industrial raw materials. These are regarded as traditional production inputs that is, not 
processed in their present form (Feenstra 1998). Their share in Bulgaria's EU-oriented exports, which because of vulnerability to weather fluctuated significantly in both periods, fell from an average of 26 percent in 1997-99 to an average of 24 percent in 2000-03. Simultaneously, however, their aggregate share in EU external imports of traditional inputs increased from an average of 0.5 percent to 0.7 percent in respective periods.

Another indication of the shift towards more processed goods in Bulgaria's export offer is a very sizable increase in the aggregate share of machinery and automobiles and parts. Their share in Bulgaria's EU-oriented exports increased from an average of 9 percent in 1996-99 to 12 percent in 2002 and 13 percent in 2003. Simultaneously, Bulgarian producers outperformed suppliers from other countries, with the aggregate share of these products in EU external imports increasing from an average of 0.09 percent in 1997-99 to 0.12 percent in 2002 and 0.14 percent in 2003. While these shares are below the share of Bulgarian exports in EU total external imports of 0.37 percent in 2003, the dynamics of change has been impressive.

Although the EU absorbed most of the increase in Bulgaria's sales of machinery and parts, the emergence of machinery as a driver of Bulgaria's exports in 2000-03 was not limited to EU markets. The share of the EU in Bulgaria's exports of these products increased from 51 percent in 2001 to 55 percent in 2003 (Table 14). But exports to other markets experienced explosive double-digit growth as well. Exports of machinery and parts to CEEC-8 rose 20 percent in 2001, 65 percent in 2002 and 28 percent in 2003. As a result, their share in Bulgaria's CEEC8-oriented exports rose from 19 percent in 2001 to 25 percent in 2002 and slightly fell in 2003 because of huge increase in sales of agricultural products. The latter exploded 70 percent in 2002 over 2003. In all, CEEC-8 took 6 percent of Bulgaria's machinery exports in 2003.

Table 14: Share of the EU-15 and pan-European partners in Bulgaria's exports in 1996-2003 (in percent)

\begin{tabular}{|c|c|c|c|c|c|c|c|c|}
\hline & 1996 & 1997 & 1998 & 1999 & 2000 & 2001 & 2002 & 2003 \\
\hline \multicolumn{9}{|l|}{ European Union (15) } \\
\hline Agricultural Food \& Feeds & 28.9 & 33.0 & 37.2 & 41.1 & 36.7 & 42.2 & 46.3 & 43.9 \\
\hline Industrial Raw Materials & 44.2 & 47.7 & 57.5 & 60.7 & 65.4 & 63.0 & 63.5 & 65.7 \\
\hline Machinery, excluding Automobiles & 35.0 & 34.0 & 38.9 & 51.7 & 52.2 & 51.0 & 49.9 & 54.6 \\
\hline Automobiles \& Parts & 62.0 & 35.2 & 42.5 & 20.0 & 40.4 & 57.5 & 69.3 & 71.9 \\
\hline Other Consumer Goods & 45.6 & 50.1 & 57.2 & 60.2 & 59.7 & 60.4 & 59.0 & 61.4 \\
\hline Fuels & 19.2 & 24.3 & 13.1 & 18.2 & 11.0 & 29.9 & 44.2 & 20.8 \\
\hline All Goods & 39.1 & 43.3 & 49.7 & 52.5 & 51.1 & 54.8 & 55.7 & 56.5 \\
\hline \multicolumn{9}{|l|}{ Pan-European countries ${ }^{1 /}$} \\
\hline Agricultural Food \& Feeds & 38.6 & 43.5 & 51.6 & 57.6 & 52.3 & 55.6 & 58.8 & 63.7 \\
\hline Industrial Raw Materials & 70.5 & 71.5 & 76.8 & 73.8 & 82.4 & 77.0 & 80.8 & 82.2 \\
\hline Machinery, excluding Automobiles & 44.0 & 44.3 & 54.5 & 60.7 & 63.2 & 62.2 & 62.8 & 64.1 \\
\hline Automobiles \& Parts & 73.4 & 58.1 & 55.1 & 25.1 & 55.3 & 66.1 & 75.6 & 79.2 \\
\hline Other Consumer Goods & 53.5 & 58.4 & 67.1 & 70.0 & 72.9 & 72.2 & 73.5 & 73.3 \\
\hline Fuels & 43.3 & 56.6 & 41.3 & 39.6 & 25.5 & 40.2 & 55.3 & 34.6 \\
\hline All Goods & 50.4 & 55.7 & 62.6 & 64.6 & 65.0 & 66.8 & 69.8 & 69.7 \\
\hline
\end{tabular}

As a result, Bulgaria has been increasingly integrating into pan-European markets for more processed goods. These markets took 64 percent of Bulgarian exports of machinery in 2003, up from 61 percent in 1999 and 79 percent of automobiles and parts in 2003, up from 55 percent in 2000. However, the latter accounted for a miniscule part of Bulgaria’s total exports.

\section{Level of technology embodied in EU-oriented exports and competitiveness}

Although, not surprisingly, low technology activities continue dominating Bulgaria's EU15 oriented exports, products of medium to high technology emerged in 2002-03 as levers of Bulgarian exports (see Section B above for the filter used to identify exports according to technological level). These products registered growth exceeding the growth of EU-oriented 
exports of manufactures in both 1997-99 and 2000-03. These exports in terms of value doubled between 2000 and 2003 and their share in manufactured exports increased from 22 percent in 2000 to 27 percent in 2003 (Table 15). In consequence, the trend dominant in 1997-98 of lowtechnology labor intensive products being the major levers of Bulgaria's exports appear to have been reversed.

Table 15: EU-oriented exports of manufactures by the type of technology involved in their production in 1996-2003 (in percent)

\begin{tabular}{|c|c|c|c|c|c|c|c|c|c|c|}
\hline & 1996 & 1997 & 1998 & 1999 & 2000 & 2001 & 2002 & 2003 & Index, 1999 & Index, 2003 \\
\hline & \multicolumn{8}{|c|}{ (in millions of US dollars) } & $1997=100$ & $2000=100$ \\
\hline Low-technology products & 1,230 & 1,429 & 1,498 & 1,306 & 1,531 & 1,851 & 1,734 & 2,252 & 91 & 147 \\
\hline Medium to high tech products & 323 & 297 & 356 & 404 & 422 & 474 & 603 & 843 & 136 & 200 \\
\hline \multirow[t]{2}{*}{ TOTAL MANUFACTURES } & 1,554 & 1,726 & 1,855 & 1,710 & 1,952 & 2,325 & 2,336 & 3,095 & 99 & 159 \\
\hline & \multicolumn{8}{|c|}{ (in terms of percent) } & & \\
\hline Low-technology products & 79 & 83 & 81 & 76 & 78 & 80 & 74 & 73 & 92 & 93 \\
\hline \multirow[t]{2}{*}{ Medium to high tech products } & 21 & 17 & 19 & 24 & 22 & 20 & 26 & 27 & 137 & 126 \\
\hline & \multicolumn{8}{|c|}{ Exports in percent of imports } & & \\
\hline Low-technology products & 190 & 227 & 208 & 180 & 189 & 196 & 163 & 156 & 79 & 82 \\
\hline Medium to high tech products & 34 & 35 & 29 & 30 & 31 & 28 & 32 & 34 & 85 & 108 \\
\hline \multirow[t]{2}{*}{ TOTAL MANUFACTURES } & 97 & 117 & 96 & 82 & 91 & 88 & 79 & 79 & 70 & 87 \\
\hline & \multicolumn{8}{|c|}{ Share in EU imports } & & \\
\hline Low-technology products & 0.68 & 0.77 & 0.76 & 0.67 & $\overline{0.74}$ & 0.90 & 0.82 & 0.90 & 88 & 120 \\
\hline Medium to high tech products & 0.10 & 0.09 & 0.10 & 0.10 & 0.10 & 0.12 & 0.15 & 0.17 & 114 & 176 \\
\hline \multirow[t]{2}{*}{ TOTAL MANÜFACTURES } & 0.30 & 0.32 & 0.32 & 0.28 & 0.29 & 0.36 & 0.36 & 0.39 & 86 & 134 \\
\hline & \multicolumn{8}{|c|}{ Export Specialization Index } & & \\
\hline Low-technology products & 2.24 & 2.36 & 2.39 & 2.41 & 2.55 & 2.50 & 2.28 & 2.28 & 102 & 90 \\
\hline Medium to high tech products & 0.36 & 0.30 & 0.31 & 0.37 & 0.33 & 0.35 & 0.44 & 0.46 & 125 & 140 \\
\hline TOTAL MANÜFACTURES & 1.05 & 1.06 & 1.02 & 1.00 & 1.00 & 1.10 & 1.04 & 1.06 & 95 & 106 \\
\hline \multicolumn{9}{|c|}{ Memorandum: share of manufactures in Bulgaria's EU-15 exports } & & \\
\hline & 70.5 & $\overline{71.6}$ & 73.0 & 71.9 & 68.7 & 74.5 & 71.0 & 72.4 & 100 & 105 \\
\hline
\end{tabular}

Source: Own calculations based on EU-15 trade data reported to the UN COMTRADE database.

Although Bulgaria's continues specializing in low-technology products in EU-15 markets, medium- to high technology intensive products have outperformed since 2000 lowtechnology products across all dimensions. They had the largest increase in competitiveness in EU-15 markets as measured by the share in EU external imports, which-after having been stagnant at around 0.10 percent in 1996-1999-increased 76 percent in 2000-03. Net exports of medium to high tech product, albeit still well below their imports, have considerably increased since 2000 in contrast to net exports of manufactures to EU-15 markets. This has taken place against the background of rapidly expanding imports, which stood in 2003-in terms of value-at 185 percent of their level in 2000. The value of Export Specialization index (ESI) in EU markets fell for low-technology products from its record level of 2.55 in 2000 to 2.28 in both 2002 and 2003. Simultaneously, the value of the ESI for medium to high technology exports has significantly increased, although it still has a long way to go to exceed the unit value indicating the status of revealed comparative advantage and specialization in EU-15 markets.

\section{Emerging top export performers in EU markets}

To what extent this shift towards trade in more technologically advanced products has impacted Bulgaria's competitiveness in EU markets? What products have emerged, as top performers in Bulgaria's EU-oriented exports during the current expansionary phase? It would be tempting to argue that Bulgaria's export basket has changed little since 1996. For instance, almost all top 20 largest exporters in 2003 were also among top 20 not only in 2002 but also in 1999 and 1996-17 products were present in 2002, 15 in 1999 and 13 in 1996. Those that failed to be among top 20 in previous years were significant exporters within the group of top 50 except for two items-electrical wires (SITC. 7731) and motor spirit and other light oils (SITC 3341). Last 
but not least, top 20 products accounted consistently for around half of Bulgarian EU-oriented exports (Table 16).

Table 16: Top twenty four-digit SITC exporters to the EU in 2003 and their rankings in 1996, 1999 and 2002

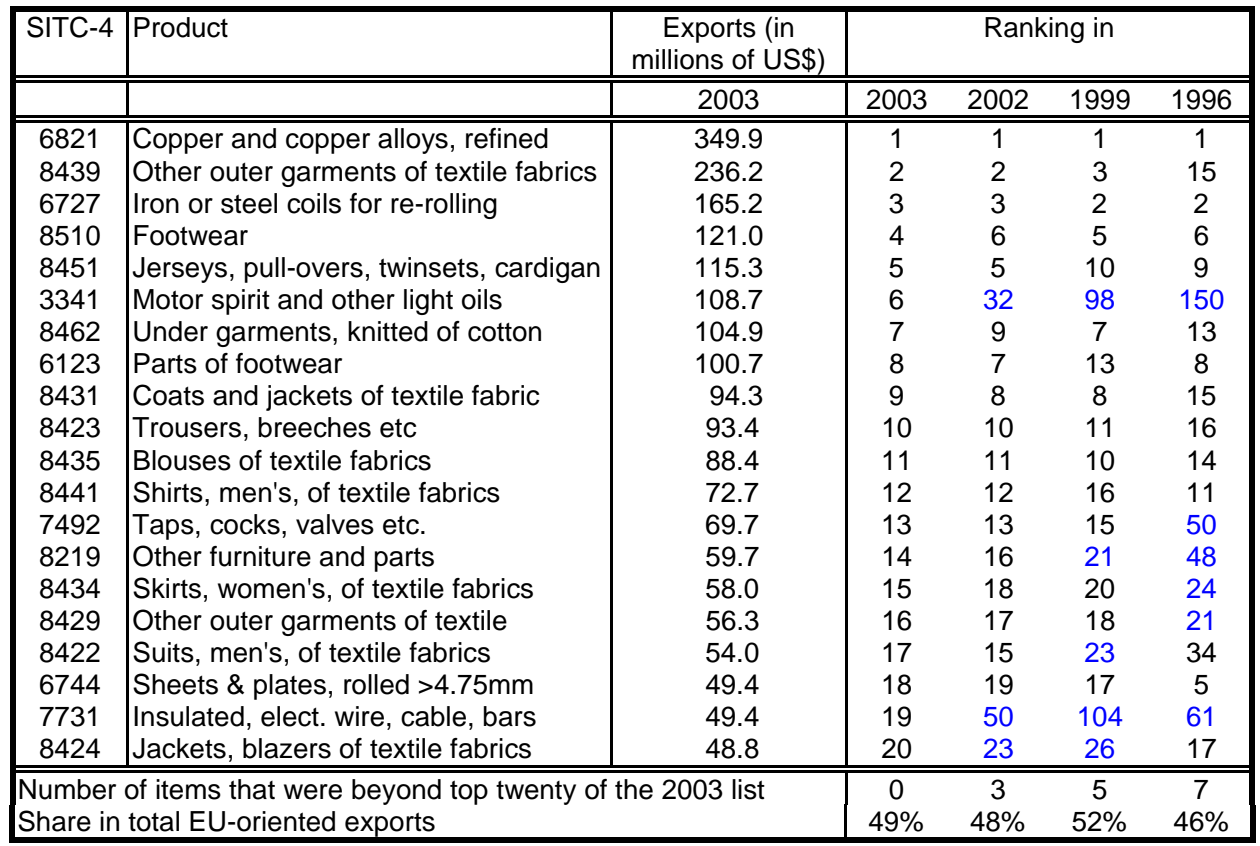

Source: Based on EU Data from UN COMTRADE Statistics.

Yet, this conclusion may not be warranted. In fact, Bulgaria's export expansion did not consist of merely exporting more of the same products. The evidence abound. First, as discussed earlier, the levers of export growth during the current phase have been medium to high technology products, with their share in manufactured exports rising 22 percent in 2000 to 27 percent in 2003. Under these conditions, it would appear that rather a considerable reshuffling in Bulgaria's export offer has been taking place.

Indeed, the analysis of the group of top export performers in 2000-03 identified in terms of the degree processing confirms the observation about significant realignment in Bulgaria's export offer (Table 17). The share of top export-products in EU-oriented exports rose rather spectacularly, albeit not unexpectedly given their at least 30 percent average growth per year in order to qualify for the status of fast grower, from 4 percent in 2000 to 16 percent in 2003. Simultaneously, the value of correlation coefficient between shares in Bulgaria's EU-oriented exports of top twenty four-digit SITC products in 2000 and 2003 was relatively low at 0.49.

Machinery and parts together with consumer products have been major drivers of this growth. The difference between the composition of Bulgaria's total EU-oriented exports and of 'top performing' exports stems largely from a discernible shift away from traditional production inputs to higher value added machinery and parts. Leaving aside 2002, when the one-year surge in exports of sunflower seeds and wheat raised the share of foods and feeds in Bulgaria's exports, the share of traditional inputs fell from 31 percent in 2000-01 to 27 percent in 2003. This share was in 2003 five percentage points higher than the share of traditional inputs in Bulgaria's total EU-oriented exports, which stood at 22 percent. But the share of machinery and parts in total exports of top performers of 38 percent is well above that in Bulgaria's total EU-oriented exports in 2003, which amounted to 'only' 13 percent. The difference in the shares of consumer goods in two export baskets was even larger: 35 percent as compared with 65 percent for total EU-oriented 
exports. If anything, this suggests that consumer goods, mainly clothing, ceased to be the major drivers of exports to the EU, as they were in 1997-99.

Table 17: Composition of fastest growers (above 30 percent on average over 2000-03) in EU markets by End-Use (in millions of US dollars and percent)

\begin{tabular}{|c|c|c|c|c|c|c|c|c|c|}
\hline & \multicolumn{4}{|c|}{ Exports (millions of US dollars) } & \multirow{2}{*}{$\begin{array}{c}\begin{array}{c}\text { Average } \\
\text { growth rate }\end{array} \\
2000-03\end{array}$} & \multicolumn{4}{|c|}{$\begin{array}{l}\text { Share in exports of top performers } \\
\text { (in percent) }\end{array}$} \\
\hline & 2000 & 2001 & 2002 & 2003 & & 2000 & 2001 & 2002 & 2003 \\
\hline Foods and feeds & 12.7 & 34.5 & 159.7 & 86.8 & 61.6 & 11.7 & 13.0 & 31.6 & 12.8 \\
\hline Industrial raw materials & 21.2 & 48.8 & 68.7 & 99.4 & 47.1 & 19.5 & 18.4 & 13.6 & 14.6 \\
\hline Automobiles and parts & 1.0 & 5.2 & 9.1 & 14.7 & 95.8 & 0.9 & 2.0 & 1.8 & 2.2 \\
\hline Machinery, excluding automobiles & 40.5 & 74.5 & 136.4 & 244.4 & 56.7 & 37.2 & 28.0 & 27.0 & 35.9 \\
\hline Consumer Goods & 33.5 & 102.6 & 132.0 & 234.9 & 62.8 & 30.7 & 38.6 & 26.1 & 34.5 \\
\hline of which textiles & 12.1 & 23.5 & 47.5 & 74.2 & 57.5 & 11.1 & 8.8 & 9.4 & 10.9 \\
\hline clothing & 2.3 & 4.2 & 7.5 & 14.9 & 59.9 & 2.1 & 1.6 & 1.5 & 2.2 \\
\hline Total (in million of US dollars) & 108.9 & 265.7 & 505.9 & 680.3 & 58.1 & 100.0 & 100.0 & 100.0 & 100.0 \\
\hline Memo: Share in total exports to EU & 3.8 & 8.5 & 15.4 & 15.9 & & & & & \\
\hline
\end{tabular}

Table 18 identifies top ten four-digit products that experienced the fastest growth in EUoriented exports over 2000-03. Except for sands (SITC 2733) and other wheat (0412), all of them are manufactures each with the value of exports exceeding US\$ 1 million in 2003. None of these exports exceeded US\$ 500,000 in 2003, and top three exported less than US\$100,000. Except for blooms (SITC 6725), with exports worth US\$ 12 million in 1997, and halogenated derivatives (5113), with exports of US\$ 1.2 million in 1996 and US\$ 1.8 million in 1997, not a single product exceeded the one-million dollar benchmark in 1996-2000. Last but not least, it is worth noting that except for air conditioners (7415) and photographic parts (8811) the shares of other products in EU external imports exceed the share of total Bulgarian exports in EU imports of 0.37 percent in 2003.

Table 18: Ten four-digit SITC sectors with the highest growth in exports in 2000-03

\begin{tabular}{|l|l|rc|cc|}
\hline & & $\begin{array}{c}\text { Exports } \\
\text { ('O00\$) }\end{array}$ & $\begin{array}{c}\text { Average growth of } \\
\text { exports }\end{array}$ & $\begin{array}{c}\text { Share in EU } \\
\text { imports }\end{array}$ & $\begin{array}{c}\text { Average growth in } \\
\text { share }\end{array}$ \\
\hline SITC-4 & Product & 2003 & $2000-03$ & 2003 & $2000-03$ \\
\hline \hline 7415 & Air conditioning machines. self-contained & 3,412 & 434 & 0.10 & 403 \\
5113 & Halogenated derivatives of hydrocarbon & 2,610 & 384 & 0.44 & 368 \\
8811 & Photographic, cameras, parts \& access & 1,078 & 203 & 0.11 & 242 \\
7451 & Tools for working in the hand, pneumatic & 3,305 & 196 & 0.43 & 174 \\
6725 & Blooms, billets, slabs \& sheet bars & 21,694 & 182 & 1.33 & 165 \\
2733 & Sands, natural, of all kinds & 4,772 & 158 & 4.62 & 148 \\
7758 & Electro-thermic appliances, n.e.s. & 24,693 & 158 & 0.64 & 126 \\
0412 & Other wheat (including spelt) & 13,262 & 156 & 1.70 & 118 \\
6760 & Rails and railway track construction & 2,179 & 146 & 1.57 & 92 \\
6781 & Tubes and pipes, of cast iron & 2,032 & 144 & 5.18 & 109 \\
\hline
\end{tabular}

Source: Based on EU Data from UN COMTRADE Statistics.

Among products with the compound annual growth rate of exports over 2000-03 exceeding 30 percent, electro-engineering industry (SITC. 76 and 77) clearly stands out. Its share in these exports grew from 6 percent in 1997 to 12 percent in 2001 and 14 percent in 2003. More significantly, while in 1996-2000 exports of electro-engineering products had merely kept pace with the growth in EU import demand, with their aggregate share fluctuating between 0.08 percent and 0.09 percent; Bulgarian firms outperformed other exporters each year in 2001-2003. The share of these products in EU external imports increased from 0.08 percent in 2000 to 0.16 percent in 2001, 0.26 percent in 2002 and 0.39 in 2003. ${ }^{12}$ The latter value was above Bulgaria's

\footnotetext{
${ }^{12}$ In consequence, the share of Bulgaria in EU external imports of machinery increased from 0.09 percent in 2001, which equaled the peak level reached in 1996, to 0.15 percent in 2002 and 0.17 percent.
} 
share in total external EU imports in 2003.

Electro-engineering products have been responsible not only for a significant increase of machinery in Bulgaria's total EU-destined exports from 2 percent in 1997-98 to 6 percent in 2003 but also for a dramatic reshuffling of Bulgaria's export offer of machinery products. Consider that the aggregate share of fast growers in Bulgaria's EU-destined exports of machinery (SITC 7) increased from 47 percent in 2000 to 63 percent in 2001 and 81 percent in 2003. Furthermore, among top four-digit SITC products of this sector in terms of growth, there are at least three relative newcomers to EU markets: radiotelegraphic and radiotelephonic items (SIT 7643), telecommunications equipment (7648) and electro-thermic appliances (7758), with their respective annual growth rates in 2000-03 of 128 percent, 123 percent and 158 percent, respectively. The values of their exports were below US\$ 500,000 in 1996. In contrast, exports of household-type refrigerators (SITC 7752), which recorded the fourth fastest growth in sales in EU markets in 2000-03, run in millions of US dollars already during this period indicating earlier established commercial presence in these markets (Table 19).

Table 19: Top four export performers in electro-engineering products in EU markets in 1996-2003 (in thousands of US dollars)

\begin{tabular}{|c|c|c|c|c|c|c|c|c|c|c|}
\hline $\begin{array}{c}\text { SITC- } \\
4\end{array}$ & Product & 1996 & 1997 & 1998 & 1999 & 2000 & 2001 & 2002 & 2003 & $\begin{array}{c}\text { Index, } \\
2003\end{array}$ \\
\hline & & \multicolumn{8}{|c|}{ (in million of US dollars) } & $2000=100$ \\
\hline $\begin{array}{l}7643 \\
7648 \\
7758 \\
7752\end{array}$ & $\begin{array}{l}\text { Radiotelegraphic \& } \\
\text { radiotelephonic } \\
\text { Telecommunications equipment } \\
\text { Electro-thermic appliances } \\
\text { Household type refrigerators } \\
\text { TOTAL ABOVE }\end{array}$ & $\begin{array}{l}0.02 \\
0.17 \\
0.21 \\
3.81 \\
4.21\end{array}$ & $\begin{array}{l}0.08 \\
0.32 \\
0.17 \\
2.23 \\
2.80\end{array}$ & $\begin{array}{l}1.12 \\
0.14 \\
0.40 \\
5.49 \\
7.16\end{array}$ & $\begin{array}{l}1.19 \\
0.68 \\
0.64 \\
4.76 \\
7.27\end{array}$ & $\begin{array}{l}0.66 \\
0.28 \\
0.56 \\
1.42 \\
2.91\end{array}$ & $\begin{array}{l}0.89 \\
0.87 \\
0.54 \\
12.2 \\
14.5\end{array}$ & $\begin{array}{r}1.9 \\
6.6 \\
11.3 \\
19.2 \\
38.9\end{array}$ & $\begin{array}{r}17.8 \\
6.8 \\
24.7 \\
30.3 \\
79.6\end{array}$ & $\begin{array}{l}2708 \\
2467 \\
4430 \\
2134 \\
2735\end{array}$ \\
\hline \multicolumn{5}{|c|}{ Memorandum: } & \multicolumn{5}{|c|}{ (in percent) } & \\
\hline 7 & $\begin{array}{l}\text { Share of the above in EU- } \\
\text { destined exports of machinery } \\
\text { Share of the above in EU } \\
\text { imports }\end{array}$ & $\begin{array}{r}5.8 \\
0.06\end{array}$ & $\begin{array}{r}6.9 \\
0.06\end{array}$ & $\begin{array}{l}13.6 \\
0.12\end{array}$ & 10.7 & $\begin{array}{r}3.8 \\
0.03\end{array}$ & 0.14 & $\begin{array}{l}23.2 \\
0.31\end{array}$ & $\begin{array}{l}31.8 \\
0.47\end{array}$ & $\begin{array}{r}834 \\
1650\end{array}$ \\
\hline
\end{tabular}

Source: Based on EU Data from UN COMTRADE Statistics.

Exports of household type refrigerators provides an interesting illustration of sectoral “hick-ups' usually triggered by restructuring. They fell dramatically in 2000 and rebounded massively the following year exceeding the earlier peak level in 1997 by a factor of 2.2.

Another indication of the ongoing change in Bulgaria's export basket triggered by industrial restructuring is the sheer growth of electro-engineering products. The value of their aggregate exports in 2003 was 27-times higher than in 2000, with their share in EU external imports rising 117-times in 2003 over the 2000 level.

\section{E. Conclusions}

The answers to three questions raised in the introduction to this section can be summarized as follows. First, changes in import demand suggest that the process of industrial restructuring has at last begun. The share of manufactures in Bulgaria's imports has not only significantly increased but, within manufactures, there has been the shift towards products with higher technology content and capital goods. Bulgaria's growing integration into pan-European markets for manufactures has accompanied this shift.

Second, Bulgaria's export offer has become more processed indicating progress in modernization of industrial capacities. The fall in the share of traditional inputs, i.e., products used for further processing, in Bulgaria's exports has been accompanied by a marked increase in the share of machinery. This, combined with the increase of more technologically advanced manufactures in Bulgaria's exports, suggests a gradual shift towards more processed exports. 
Third, recent star performers in highly competitive EU-15 markets, now accounting for 16 percent of Bulgaria's exports up from 4 percent in 2000, are mainly electro-engineering products. Exports of machinery top the list, contributing almost 40 percent to the total of top performers' exports. Hence, new exports come mainly from restructured industrial capacities auguring well for future competitiveness in international markets.

\section{Factor endowments and patterns of specialization}

Considering endowment of Bulgaria in factors of production - temperate climate, available land for agricultural production and educated labor force-one would expect skilled labor intensive and natural resource intensive products dominate its export basket. The factor intensities of Bulgaria's EU-oriented exports in 1991-96 were not in line with these expectations (Figure 4).

These developments raise several important questions: How has its export basket in terms of factor intensities evolved over time? Did the initial specialization in skilled labor intensive and capital intensive deviate from Bulgaria's real patterns of comparative advantage? Was it a fad reflecting misguided socialist industrialization not sustainable in confrontation with realities of market competition? Or, alternatively, has Bulgaria's endowment in factors of production changed since the collapse of central planning and its current exports simply reflect this new reality? In answering these questions, we shall focus on highly contestable EU markets, as the latter provide a sharp image of the revealed capacity of Bulgarian producers to compete in products with different factor intensities.

\section{A. Bulgaria's endowment in factors of production}

What is Bulgaria's endowment in factors of production? Historically, under central planning and specialization assigned within the now defunct CMEA, Bulgaria specialized in skilled labor and resource intensive products. But since almost 15 years have passed since the collapse of central planning have passed, a more pertinent question relates to products in which in terms of their factor intensity that Bulgaria is predetermined to specialize now. Data tabulated in Table 8 offer some glimpses to this question by shedding light Bulgaria's endowments in the perspective of other CEEC-10 including Croatia and Romania. First, Bulgaria is well endowed with land; although the land per capita is slightly below the average for both CEEC-11 economies and the EU-15, Bulgaria has relatively more arable land. While the comparators do not include all potential competitors in pan-European markets, and therefore no firm conclusion can be drawn about comparative advantage, one may expect the potential for specialization in agricultural products. Like most other CEEC-10, except Poland and Romania, Bulgaria does not have any significant deposits of natural resources. The value of natural resource index, which ranges between zero (no resources) and two (very well endowed), was zero. Poland and Romania got the score of one. Thus, notwithstanding the differences in GDP per capita and deposits of minerals, CEEC-11 countries have rather comparable endowments in terms of the potential to specialize in natural resource intensive products.

Second, Bulgaria is a net exporter of electricity. Its consumption per capita is slightly lower than the CEEC-11 average. This combination points to some potential for the development of energy intensive production lines provided that its price is competitive.

Last but not least, the data suggests that Bulgaria is well endowed with skilled labor force. Although the proportion of labor with secondary education is below the average for CEEC11 , but the difference is not large and the value of this indicator is still above the average for the EU-15. Together with relatively low level value of the indicator of labor market participation (see note to Table 20), this suggests a significant potential for the expansion of skilled labor intensive production. 
Table 20: Bulgaria's endowments in comparative perspective: CEEC-11 and EU-15

\begin{tabular}{|c|c|c|c|c|c|c|c|c|}
\hline & $\begin{array}{c}\text { Land, } \\
\text { km2 } \\
\text { per } \\
\text { capita }\end{array}$ & $\begin{array}{l}\text { Land use, } \\
\text { arable land } \\
\text { (\% of land } \\
\text { area), } \\
2001\end{array}$ & $\begin{array}{c}\text { Economically } \\
\text { active population } \\
\text { with secondary } \\
\text { education }(\%)\end{array}$ & $\begin{array}{c}\text { Economically } \\
\text { active } \\
\text { population (\% of } \\
\text { total population) }\end{array}$ & $\begin{array}{c}\text { Labor } \\
\text { Market } \\
\text { Partici- } \\
\text { pation /b }\end{array}$ & \begin{tabular}{|c|} 
Electricity \\
production \\
(kwh per \\
capita) \\
2002 \\
\end{tabular} & \begin{tabular}{|c|} 
Electricity \\
consumption \\
(kwh per \\
capita), \\
2002 \\
\end{tabular} & $\begin{array}{c}\text { Natural } \\
\text { Resources } \\
\text { Index, } \\
2004 \text { /c }\end{array}$ \\
\hline Bulgaria & 0.014 & 40.0 & 55.3 & 42.0 & 49.2 & 5,424 & 3,056 & 0 \\
\hline Croatia & 0.013 & 26.1 & $60.4 / 3$ & .. &.. & 2,752 & 2,834 & 0 \\
\hline Romania & 0.010 & 40.8 & 60.2 & 44.4 & 54.7 & 2,463 & 4,979 & 1 \\
\hline Czech Republic & 0.008 & 39.8 & 79.2 & 50.0 & 59.3 & 7,484 & 3,882 & 0 \\
\hline Estonia & 0.031 & 16.0 & 58.1 & 48.9 & 58.7 & 6,278 & 3,099 & 0 \\
\hline Hungary & 0.009 & 50.1 & 65.7 & 41.2 & 49.8 & 3,559 & 2,074 & 0 \\
\hline Latvia & 0.027 & 29.7 & 65.8 & 48.5 & 57.5 & 1,700 & 1,929 & 0 \\
\hline Lithuania & 0.019 & 45.2 & 63.2 & 47.4 & 58.2 & 5,108 & 2,498 & 0 \\
\hline Poland & 0.008 & 45.9 & 70.9 & 44.4 & 54.7 & 3,770 & 1,595 & 1 \\
\hline Slovak Republic & 0.009 & .. & 79.1 & 48.7 & 60.2 & 6,028 & 4,222 & 0 \\
\hline Slovenia & 0.010 & 8.6 & 63.2 & 49.0 & 56.5 & 7,480 & 5,998 & 0 \\
\hline CEEC-11 /d & 0.014 & $34.2 / 1$ & 66.1 & 46.4 & 55.9 & 4,732 & 3,288 & \\
\hline $\begin{array}{l}\text { Bulgaria as \% of } \\
\text { CEEC-11 average }\end{array}$ & $98 \%$ & $117 \%$ & $84 \%$ & $90 \%$ & $88 \%$ & $115 \%$ & $93 \%$ & \\
\hline EU15 /d & 0.014 & $24.3 / 2$ & $44.4 / 4$ & 47.1 & 56.7 & 7,073 & 6,086 & \\
\hline
\end{tabular}

Notes: All data are for 2003, unless otherwise specified; 1/ Excluding Slovak Republic; 2/ Excluding Luxembourg; /3 2001 data; 4/ Excludes France (no secondary ed. data available); 2002 data used for the Netherlands.

la Upper secondary and post-secondary non-tertiary education - levels 3-4 (ISCED 1997);

/b ILO Methodology: Economically active population divided by total population over 15.

/c Falcetti et al. EBRD 2004. Countries are rated from 0 to 2, 2 being the highest.

/d Simple average.

Sources: EUROSTAT, WDI 2004.

Furthermore, the cost of labor as measured in terms of the average gross monthly wage is very low by regional standards. In fact, it was well below the levels not only in CEEC-8, i.e., new EU members, but also in SEE countries. Albania's average gross monthly, the second lowest, was 11 percent higher in 2003 and 23 percent higher in 2004. Romania's average wage was 30 percent above that of Bulgaria's in 2004. Had there been no other constraints, this alone would have made Bulgaria extremely attractive for labor intensive activity.

In all, like other CEEC-10, Bulgaria has the potential to specialize in labor intensive products, with the possible bias in favor of skilled labor intensive goods, and, to a lesser extent, natural resource intensive products embracing mostly agricultural goods. On might also add to this list the capital-intensive goods, albeit with a caveat. The experience of transition countries shows significant contribution of FDI taking advantage of relatively cheap and highly skilled labor thus reducing relative shortage of capital.

\section{B. Factors content of Bulgaria's exports in comparative perspective}

Patterns in trade in goods reflect differences in comparative advantage as determined by different factor endowments among countries. A country tends to export those goods, which use factors in relative abundance. However, this fully takes place if there is a competitive market mechanism efficiently allocating resources. By the same token, the persistence in disconnect between country's endowments in factors of production and factor intensities of its exports point to major institutional and policy deficiencies in the existing economic regime.

Exploring a full causal chain linking factor endowments, comparative advantage and trade patterns are not relevant for this discussion. ${ }^{13}$ The question germane here concerns

\footnotetext{
${ }^{13}$ The goodness of results obtained hinges critically on the quality of a classification used to examine export baskets over time by factor mix. The choice is always controversial. There are woeful difficulties to define and measure factor intensity, and trade theorists have long wrestled with it. Special problems emerge when a classification aims to capture "quality" of factors involved (Winters 1997). Some definitions of the groups of goods by factor intensity are overlapping and non-exhaustive. Definitions used here do not suffer
} 
assessment of broad changes in relative factor intensities as revealed in Bulgaria's total exports in comparison to other transition economies.

Historically, under central planning and specialization assigned within the now defunct CMEA, Bulgaria's comparative advantage was 'planned to be' in skilled labor and capital intensive products. Considering its moderate climate and abundance of fertile soil, Bulgaria's another specialization were agricultural, resource intensive products. Electrical machinery accounted for a sizable share of its CMEA-directed exports, albeit not in exports directed to world markets where low-processed products and raw materials, industrial and agricultural, were dominant. Like other CEEC-10 economies, Bulgaria's foreign trade was subject to a dual regime-administrative and market-oriented. They both overlapped creating 'policy-induced' comparative advantage.

However, with the end of the CMEA - trade driven more by politics than economics, this pattern of factor intensities of exports was not sustainable at least in the short run. Although relative to its GDP per capita Bulgaria had a relatively large pool of high skilled labor, its stateowned enterprises turning on capital and skilled labor intensive products could not survive without infusion of capital and technology. Even with privatization to foreign strategic investors, it would take some time before they could be restructured to become competitive in international markets. Similarly, earlier specialization in agricultural products was not sustainable. Their competitiveness was artificially sustained by subsidized energy and other, implicit and explicit subsidies. Again it would take time before reforms of agricultural sector would bring indispensable improvements in productivity to withstand competition in world markets.

For these reasons, one would expect that in the aftermath the collapse of central planning and CME trade there would be an initial shift towards unskilled labor intensive products, as it was the case in other transition economies, followed by the shift towards agricultural and skilled labor intensive products. Over a longer haul, one would, therefore, expect dominance of labor intensive and natural resource intensive products in its exports. Given the relatively high quality and degree of scientific education in Bulgaria as well as in other Central European countries, Hamilton and Winters (1992) pointing to a positive correlation between education and comparative advantage in sophisticated engineering goods had predicted a better-than-average performance in skilled labor intensive products. Developments several years into transition have substantiated this prediction. Unskilled labor intensive products were the major levers of CEEC-3 EU-oriented export expansion (Kaminski 1993).

Bulgaria's pattern in terms of export intensities has been similar to those observed in Central European transition economies but only in 1990-96. The drivers of export growth to the EU were initially unskilled labor rather than skilled labor intensive products. ${ }^{14}$ Unskilled labor intensive industrial products were also the driving force behind Bulgaria's EU-oriented export growth. The value of these exports increased 58 percent between 1991 and 1993 (as compared to

from these shortcomings--all industries are taken into account and an industry appears only in one classification; and the classification distinguishes among four types of factors. Since some industries are intensive in terms of more than one factor, the results may be distorted. But even assuming that the initial classification captures adequately factor proportions at a given point of time, with the passage of time it may provide a distorted picture. Some industries may become more capital-intensive or less active in technological terms.

${ }^{14}$ For instance, in Hungary the share of unskilled labor products rose 32 percent over 1989-93 as compared to 22 percent and 19 percent change in the share of capital intensive and skilled labor intensive products mainly at the expense of a dramatic fall in resource intensive exports (-46 percent). Thereafter, the share of unskilled labor fell 36 percent between 1993 and 1997, the share of capital intensive rose 74 percent and that of skilled labor intensive products 47 percent. 
a 19-percent increase in total EU-destined exports), and their share rose from 24 percent to 32 percent. But it fell to 28 percent in 1994. Since the share of unskilled labor intensive products in EU-oriented exports of Czech Republic, Hungary and Poland had also been contracting since 199293, there was nothing unusual about it. ${ }^{15}$

However, while 1992-93 witnessed what turned out to be historically peak levels of the shares of unskilled labor intensive products in EU-oriented exports from these countries, Bulgaria's pattern has been diverging. The 1994-96 witnessed a major realignment in the export growth pattern, with skilled labor and capital intensive products emerging as major levers of Bulgaria's export expansion, turned out not to be sustainable (Figure 4). ${ }^{16}$

Figure 4: Factor intensities of Bulgaria EU-oriented exports in 1991-2003(in percent)

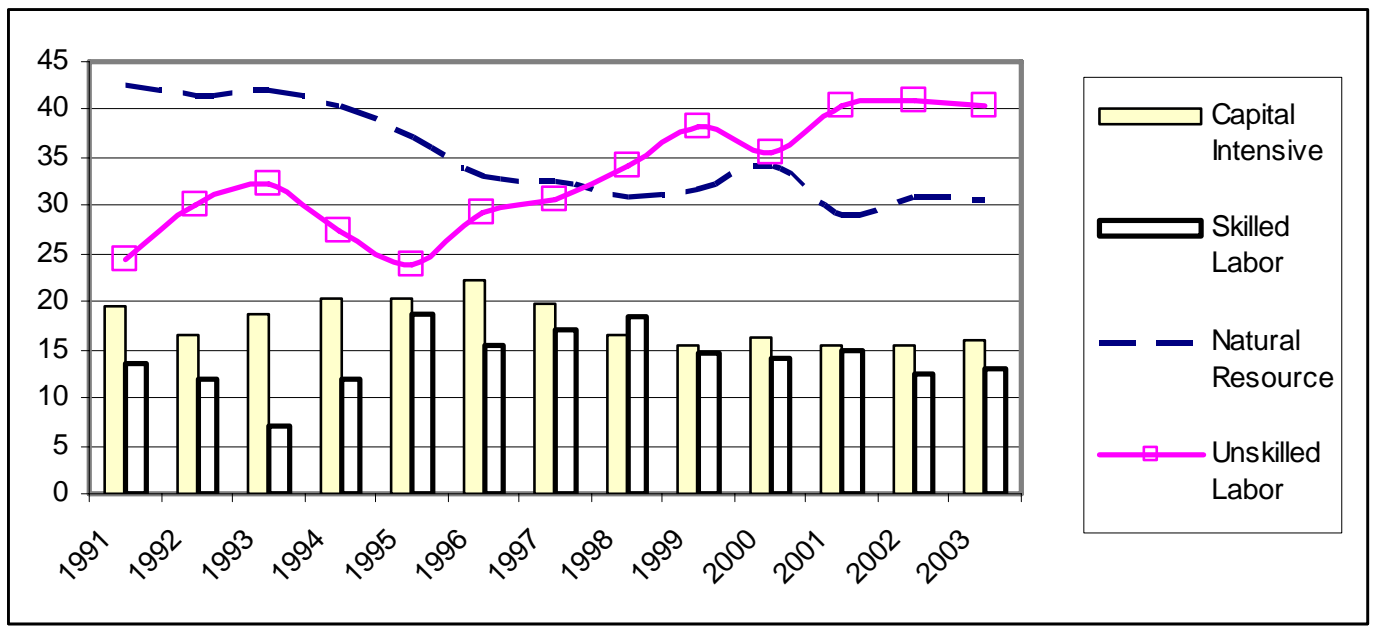

Source: Based on EU Data from UN COMTRADE Statistics.

Bulgaria's pattern in terms of export intensities has become a complete reversal of patterns observed in Hungary or Poland as well as in other transition economies in that period. This was a repetition of the patterns observed during the initial stages, albeit on a much larger scale, as the share of unskilled labor intensive products rapidly expanded to levels well above the earlier peak in 1993 and their expansion extended over a much longer period of time. The share of both skilled labor and capital intensive products in Bulgaria's EU exports after increases in 1994-95 has subsequently, whereas unskilled labor intensive drove Bulgaria's exports until 2001, with their share rising to 40 percent and stabilizing at this level.

Bulgaria's idiosyncratic factor intensities extended to total exports still in 1996 (first year for which reliable foreign trade data are available). Given the relative endowments in capital across regional peers, one would not expect such a significant presence of capital intensive products in Bulgaria's total exports. Yet, the share of capital intensive products was higher in Bulgaria's exports than in total exports of all other comparators in 1996 (Table 21). This may come as no surprise vis-à-vis SEE-4, but it is rather startling when cast against much more developed CEEC-8 economies taken as a bloc. The share in CEEC-8 exports was four percentage points lower than in Bulgaria's, while the share of unskilled labor products four percentage points larger. In a similar vein, unskilled labor intensive products had much larger presence in both Croatian and Romanian exports than in Bulgaria's.

\footnotetext{
${ }^{15}$ See the calculations reported in World Bank 1999.

${ }^{16}$ The value of total EU-oriented exports increased 85 percent in 1993-96. The value of skilled labor intensive products quadrupled and that of capital intensive exports. Simultaneously, the share of unskilled labor intensive declined
} 
Table 21: The differences between Bulgaria's exports and other CEEC-and SEE-economies in terms of factor intensities in 1996, 2000 and 2003 (in percentage points and in percent)

\begin{tabular}{|c|c|c|c|c|c|c|c|c|c|c|c|c|}
\hline & \multicolumn{4}{|c|}{1996} & \multicolumn{4}{|c|}{2000} & \multicolumn{4}{|c|}{2003} \\
\hline & NR & UL & $\mathrm{Cl}$ & SL & NR & UL & $\mathrm{Cl}$ & $\mathrm{SL}$ & NR & UL & $\mathrm{Cl}$ & SL \\
\hline CEEC-8 & -12.1 & 4.3 & -3.9 & 8.2 & -16.6 & -9.3 & 10.6 & 13.8 & -16.4 & -15.2 & 14.6 & 16.3 \\
\hline Of which: Lithuania & 5.5 & 3.1 & -6.4 & -2.2 & 8.5 & -1.1 & -1.5 & -5.8 & 6.1 & -3.7 & -0.7 & -1.7 \\
\hline Croatia & -4.9 & 17.9 & -4.2 & -8.8 & -1.9 & 7.2 & 1.8 & -7.1 & -5.0 & 1.4 & 7.6 & -4.0 \\
\hline Romania & -15.0 & 21.9 & -8.4 & 1.5 & -12.9 & 14.2 & -0.1 & -1.1 & -11.3 & 8.3 & 0.1 & 2.9 \\
\hline SEE-4 & 17.1 & 2.0 & -15.8 & -5.3 & 9.0 & -2.6 & -10.0 & 2.4 & 13.9 & -7.7 & -7.5 & 0.1 \\
\hline \multicolumn{13}{|c|}{\begin{tabular}{|l|l|} 
Memorandum: Share in percent in Bulgaria's total exports \\
\end{tabular}} \\
\hline Bulgaria & 37.7 & 17.1 & 28.3 & 16.9 & 35.2 & 27.1 & 21.5 & 16.2 & 34.0 & 32.2 & 18.9 & 14.9 \\
\hline
\end{tabular}

Notes: NR-natural resource intensive products; UL-unskilled labor intensive products; Cl-capital intensive products; SLskilled labor intensive products. SEE-4 countries include Albania, Macedonia, Moldova and Serbia and Montenegro. Because of lack of data, Bosnian and Herzegovina is not included.

Source: Derived from countries' data in UN COMTRADE database.

The 1996-2003 period has seen shifts in factor content of Bulgaria's exports vis-à-vis its regional peers that in most CEEC-8 took place during the initial stages of transition in 1991-95. First, exports of CEEC-8 moved towards capital intensive products: their share was 11 percentage points higher than in Bulgaria's exports in 2000 and rose further to 15 percentage points in 2003. Similar change has occurred in skilled labor intensive products, with the gap widening from 8 percentage points in 1996 to 16 percentage points in 2003. This shift is also visible when compared with Lithuania, an economy with a heavy presence of natural resource intensive exports. Lithuania moved between 1996 and 2003 away from unskilled labor intensive exports to capital and skilled labor intensive products in comparison to Bulgaria.

Second, the difference in relative factor intensities vis-à-vis its northern neighbor, Romania, has narrowed mainly as a result of the growth in Bulgaria's exports of unskilled labor intensive product and the fall in the share of skilled labor intensive products in total exports. Romania's export basket has moved more towards capital and skilled labor intensive products in comparison with Bulgaria. Last but not least, SEE-4 exports moved between 2000 and 2003 relative to Bulgaria's exports towards natural resource intensive products.

Data in Table 22 provide another set of insights based on dynamics of total exports. Lithuania's export basket in terms of relative factor intensities was the closest to that of Bulgaria in the 1996-2003 period. In Lithuania's exports, however, the share of natural resource and unskilled labor intensive was slightly larger in 1996. The situation changed already in 2000 indicating growing differences in the dynamics of exports in terms of their factor intensities, although among European transition economies Lithuania's composition of exports has remained the most similar to that of Bulgaria.

Table 22: Change in shares and dynamics of total exports in comparative perspective in 1996-2003 (in percent)

\begin{tabular}{|c|c|c|c|c|c|c|c|c|c|c|}
\hline & \multicolumn{4}{|c|}{$\begin{array}{c}\text { Index, 2000; } \\
\text { 1996=100 }\end{array}$} & \multicolumn{4}{|c|}{$\begin{array}{l}\text { Index 2003; } \\
2000=100\end{array}$} & \multicolumn{2}{|c|}{$\begin{array}{l}\text { Memorandum: Index of total exports } \\
\text { in } 2000 \text { and } 2003 \text { in terms of value }\end{array}$} \\
\hline & NR & UL & $\mathrm{Cl}$ & SL & NR & UL & $\mathrm{Cl}$ & SL & $1996=100$ & $2000=100$ \\
\hline Bulgaria & 93 & 158 & 76 & 96 & 97 & 119 & 88 & 92 & 99 & 156 \\
\hline CEEC-8 (2004 EU) & 73 & 83 & 132 & 119 & 95 & 95 & 104 & 104 & 142 & 164 \\
\hline Of which: Lithuania & 101 & 128 & 92 & 70 & 92 & 110 & 91 & 127 & 113 & 188 \\
\hline Croatia & 102 & 98 & 97 & 111 & 87 & 98 & 113 & 121 & 91 & 139 \\
\hline Romania & 98 & 106 & 108 & 81 & 102 & 98 & 89 & 119 & 128 & 170 \\
\hline SEE-4 & 81 & 128 & 93 & 160 & 109 & 100 & 98 & 81 & 97 & 130 \\
\hline
\end{tabular}

Notes: NR—natural resource intensive; UL-unskilled labor intensive; Cl—capital intensive; SL—skilled labor intensive Source: Derived from countries' data in UN COMTRADE database.

However, change in shares and dynamics of total exports shows that (a) Lithuania experienced a stronger growth in both periods and (b) exports of skilled labor products replaced 
unskilled labor products as the major levers of Lithuanian export expansion. In contrast, unskilled labor intensive products were the best performers in Bulgarian exports. In both periods, the shares of capital intensive and skilled labor intensive products in total exports of CEEC-8 increased whereas they fell in Bulgarian exports. Croatia's exports, except for much slower overall growth, displayed similar change as CEEC-8.

While this should come as no surprise considering Bulgaria's two, rather than one, transformational recessions, the comparison with Romania, which has also gone through them, raises concerns. Growth in Romania's exports was much more robust in 1996-2003 exceeding in 2000-03 the increase in CEEC-8 exports. But more importantly, skilled labor intensive products replaced capital intensive and unskilled labor intensive products as main levers of impressive growth in 2000-03. Both Bulgaria's and Romania's performance, differences between them notwithstanding, diverged from that of SEE-4, where natural resource intensive products were behind their overall rebound in exports in 2000-03.

\section{What do developments in trade with the EU say about labor markets?}

While a comprehensive answer to this question would require a detailed analysis of the labor market itself, the evidence from developments in the factor intensity of Bulgaria's trade with the EU suggests that the cost of labor relative to capital is low. On the other hand, however, the country's double-digit unemployment rate would seem to reflect the relatively high labor cost. Since wage rates are low, this in turn would suggest high cost of compliance with labor market regulations, which effectively makes labor much more expensive than wage rates alone would suggest. Although Bulgaria's export basket reflects the abundance of cheap labor, high unemployment rates would point to barriers preventing full exploitation of this potential. While some of them maybe related to distance and weaknesses in services linking domestic markets with international markets, other stem from domestic rigidities.

Labor market rigidities appear to account for the continuing high share of inter-industry type of trade in Bulgaria's foreign trade. Despite change in the dynamics of exports towards more processed, higher value added products, Bulgaria's trade still exhibits many features of the traditional division of labor linking developing and highly developed countries through exchanges of raw materials and low-processed goods for processed ones. Bulgaria specializes in the export of production inputs. Excluding clothing, agricultural raw materials and industrial inputs regarded as traditional production inputs, that is, not processed in their present form, have consistently accounted for half of EU-destined total exports minus clothing, while highly processed manufactures have dominated in imports from the EU. Although manufactures amount to more than three-fourths of Bulgaria's sales in EU markets, half of these are relatively low value-added items such as clothing and footwear.

Labor market rigidities appear to be responsible also for a high presence of unskilled labor intensive products, again clothing dominant among them, in Bulgaria's exports at the expense of skilled-labor-intensive products. Considering that wage differentials between the EU15 and CEEC-10 tend to be much higher in favor of the former for skilled labor, one might expect a more pronounced presence of skilled-labor-intensive products in EU-oriented exports. In other words, skilled labor intensive activities should have attracted capital, foreign and domestic alike. Labor market rigidities raising the cost of labor appear to have erected the barrier to allocation of capital to these areas.

Considering the prolonged period of FDI inflows well above five percent in terms of GDP as well as the increase in investment levels in the Bulgarian economy, an interesting question is the extent to which apparent labor market rigidities continue to distort investment flows as captured in their impact on exports. 


\section{Factors' content and emerging patterns of specialization in EU markets}

The share of the EU in Bulgaria's trade has been growing since the collapse of central planning. Sales in EU markets have largely determined Bulgaria's overall export performance. Several questions arise in this context: What products in terms of factor intensities have driven this expansion? How firmly entrenched are they in EU markets?

The anomaly of Bulgaria's export performance in terms of factor intensities, that is, relatively weak growth of unskilled labor exports, disappeared during the crisis phase of 1997-99, with exports of both capital and skilled labor intensive products significantly retracting. While the 1996-99 period sets Bulgaria apart from other CEEC-10 in terms of prolonged stagnation in EUoriented exports, the emergence of unskilled labor intensive product as the only 'growth' group was similar to trends observed in other CEEC-10 economies during the initial stages of transition. Unskilled labor intensive products, mainly clothing, were the only exports that consistently grew in terms of value over 1997-99 with an average annual rate of 7 percent. Their share in total EUdestined exports grew from 24 percent in 1995 to 38 percent mainly at the expense of capital and skilled labor intensive products, whose aggregate share declined from 39 percent to 29 percent (Table 23). Reflecting differences in endowment in production factors between the EU and Bulgaria, Bulgaria's exports of both natural resource and unskilled labor intensive products were significantly larger than their imports from the EU.

Table 23: Dynamics of EU-oriented exports in terms of factor intensities (in percent)

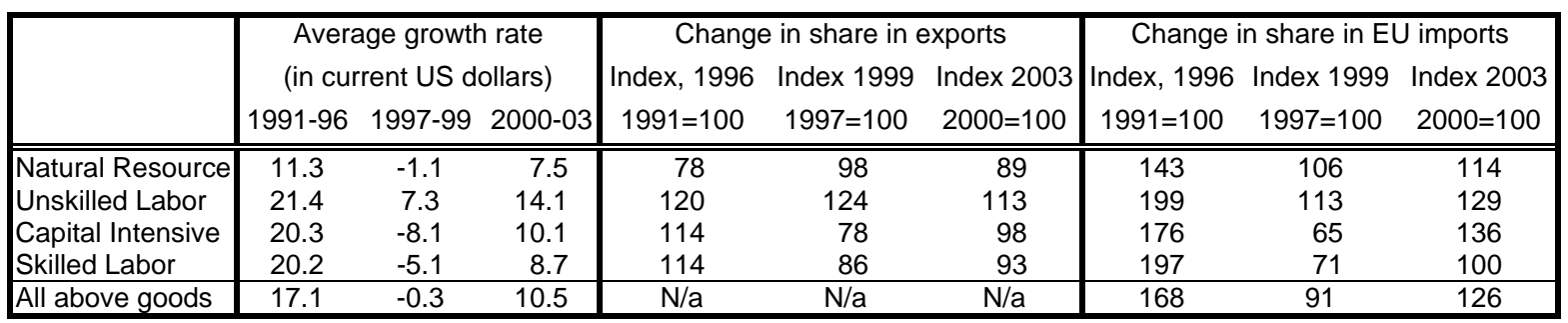

Source: Based on EU Data from UN COMTRADE Statistics.

Notwithstanding differences in dynamics, Bulgaria's specialization profile, as captured by export specialization (ES) indices, ${ }^{17}$ has remained unchanged during transition. Bulgaria has had "revealed comparative advantage" in unskilled labor and natural resource intensive products in EU markets. Except for natural resource intensive products in 1996-97 and 2001, the values of ES for both groups have been above unity in 1991-2003 (Table 24). However, the intensity of specialization in unskilled labor intensive products in EU markets has been very strong, whereas that in natural resource intensive products has been much weaker and declining.

The changes in the shares of factor intensity groups in EU external imports over 19912003 further corroborate these observations. Bulgarian producers of unskilled intensive products have consistently outperformed their competitors from other countries and seen their share in EU imports growing almost each year over 1991-2003. Performance of natural intensive producers in Bulgarian was rather lackluster. Their share in EU external imports exceeded its 1995 peak level of the 1990's only in 2002-03 and only by three percentage points. Producers of both skilled labor

${ }^{17}$ The export specialization index $\left(\mathrm{ES}_{\mathrm{ij}}\right)$ for a product $j$ of country $i$, is specified here as follows: $\mathrm{ES}_{\mathrm{ij}}=$ $\left(\mathrm{x}_{\mathrm{ij}} / \mathrm{Xi}\right) /\left(\mathrm{m}_{\mathrm{j}} / \mathrm{M}\right)$, where: $\mathrm{x}_{\mathrm{ij}}$ is country i's exports of product $\mathrm{j}$ to the $E U ; X_{i}=\Sigma j \mathrm{x}_{\mathrm{ij}}$ is country i's total exports to the EU; $M_{j}=\Sigma j x_{i j}$ is EU's total 'external' imports of a product $j ; \quad M=\Sigma i ~ \Sigma j x_{i j}$ is EU's total external imports. A value for this index below unity indicates a comparative disadvantage. If the index takes a value greater than unity, the country is considered to have a "revealed" comparative advantage in the product. In this particular case, Bulgaria has a revealed comparative advantage in a product if its export of that item as a share of its total exports exceeds the EU imports of the item as a share of EU total imports. 
intensive and capital intensive products lost shares in EU external imports. Despite gains in 200203, the share of capital labor intensive products in EU imports stood at 67 percent of its peak level in 1995 and that of capital intensive products at 89 percent (Table 7). Moreover, the share of skilled labor intensive products in EU imports fell from 0.33 percent in 2001 to 0.27 in 2002 and slightly rebounded to 0.29 percent in 2003.

Table 24: EU-oriented exports in terms of factor intensities in 1991-2003(in millions of US dollars and percent)

\begin{tabular}{|c|c|c|c|c|c|c|c|c|c|c|c|c|c|}
\hline & 1991 & 1992 & 1993 & 1994 & 1995 & 1996 & 1997 & 1998 & 1999 & 2000 & 2001 & 2002 & 2003 \\
\hline \multicolumn{14}{|c|}{ Export To EU (in Millions of \$) } \\
\hline Natural Resource & 422 & 520 & 494 & 680 & 885 & 721 & 771 & 776 & 746 & 962 & 899 & 982 & 1,285 \\
\hline Unskilled Labor & 241 & 378 & 381 & 463 & 572 & 636 & 728 & 862 & 899 & 1,002 & 1,252 & 1,299 & 1,696 \\
\hline Capital Intensive & 193 & 206 & 220 & 343 & 484 & 486 & 472 & 417 & 367 & 458 & 481 & 492 & 674 \\
\hline Skilled Labor & 133 & 150 & 83 & 201 & 449 & 335 & 404 & 462 & 345 & 394 & 466 & 397 & 550 \\
\hline All above goods & 989 & 1,254 & 1,179 & 1,687 & 2,390 & 2,178 & 2,376 & 2,518 & 2,357 & 2,816 & 3,099 & 3,170 & 4,205 \\
\hline \multicolumn{14}{|l|}{ Export Share (\%) } \\
\hline Natural Resource & 42.6 & 41.4 & 41.9 & 40.3 & 37.0 & 33.1 & 32.5 & 30.8 & 31.7 & 34.2 & 29.0 & 31.0 & 30.6 \\
\hline Unskilled Labor & 24.3 & 30.2 & 32.3 & 27.5 & 23.9 & 29.2 & 30.7 & 34.3 & 38.1 & 35.6 & 40.4 & 41.0 & 40.3 \\
\hline Capital Intensive & 19.5 & 16.4 & 18.7 & 20.3 & 20.2 & 22.3 & 19.9 & 16.6 & 15.6 & 16.3 & 15.5 & 15.5 & 16.0 \\
\hline Skilled Labor & 13.5 & 12.0 & 7.0 & 11.9 & 18.8 & 15.4 & 17.0 & 18.4 & 14.7 & 14.0 & 15.0 & 12.5 & 13.1 \\
\hline \multicolumn{14}{|c|}{ As percent of EU External Imports } \\
\hline Natural Resource & 0.20 & 0.25 & 0.25 & 0.32 & 0.36 & 0.28 & 0.31 & 0.34 & 0.32 & 0.33 & 0.32 & 0.37 & 0.37 \\
\hline Unskilled Labor & 0.30 & 0.43 & 0.45 & 0.52 & 0.57 & 0.60 & 0.65 & 0.73 & 0.74 & 0.79 & 0.97 & 0.96 & 1.01 \\
\hline Capital Intensive & 0.10 & 0.10 & 0.12 & 0.16 & 0.18 & 0.18 & 0.16 & 0.13 & 0.11 & 0.12 & 0.13 & 0.14 & 0.16 \\
\hline Skilled Labor & 0.16 & 0.17 & 0.10 & 0.23 & 0.43 & 0.31 & 0.36 & 0.36 & 0.26 & 0.29 & 0.33 & 0.27 & 0.29 \\
\hline All above goods & 0.17 & 0.21 & 0.21 & 0.28 & 0.33 & 0.29 & 0.31 & 0.31 & 0.28 & 0.30 & 0.34 & 0.35 & 0.37 \\
\hline \multicolumn{14}{|c|}{ Export Specialization Index } \\
\hline Natural Resource & 1.14 & 1.15 & 1.19 & 1.16 & 1.08 & 0.96 & 0.98 & 1.09 & 1.14 & 1.11 & 0.94 & 1.05 & 1.00 \\
\hline Unskilled Labor & 1.73 & 2.03 & 2.09 & 1.86 & 1.71 & 2.05 & 2.09 & 2.32 & 2.60 & 2.65 & 2.87 & 2.73 & 2.71 \\
\hline Capital Intensive & 0.58 & 0.49 & 0.55 & 0.57 & 0.55 & 0.60 & 0.53 & 0.41 & 0.37 & 0.40 & 0.39 & 0.40 & 0.43 \\
\hline Skilled Labor & 0.92 & 0.78 & 0.47 & 0.81 & 1.28 & 1.08 & 1.16 & 1.14 & 0.91 & 0.96 & 0.99 & 0.76 & 0.76 \\
\hline \multicolumn{14}{|c|}{ Exports in percent of imports } \\
\hline Natural Resource & 139 & 149 & 103 & 130 & 155 & 166 & 175 & 148 & 162 & 192 & 159 & 175 & 156 \\
\hline Unskilled Labor & 167 & 160 & 123 & 136 & 124 & 144 & 144 & 142 & 144 & 141 & 144 & 130 & 130 \\
\hline Capital Intensive & 34 & 33 & 42 & 50 & 60 & 72 & 77 & 49 & 36 & 45 & 37 & 34 & 36 \\
\hline Skilled Labor & 46 & 39 & 21 & 42 & 59 & 58 & 85 & 74 & 56 & 63 & 64 & 48 & 48 \\
\hline All above goods & 75 & 79 & 69 & 83 & 92 & 102 & 117 & 97 & 87 & 99 & 90 & 83 & 82 \\
\hline
\end{tabular}

The aggregates, however, do not allow determining the extent to which the reduction in distortions generated by economic reforms has triggered the process of relocation of resources to new lines of production. A different picture emerges from the analysis of export growth and changes in shares in EU external imports at four-digit SITC Rev. 2 level. Table 25 presents the composition of Bulgarian EU-oriented exports of products whose share in EU imports grew at least at an average annual growth of 30 percent amounting at a minimum to 2.85-fold increase in this share in 2003 over 2000. 141 four-digit SITC items, accounting in 2003 for 16 percent of Bulgaria's EU-destined exports, met this criterion. Their exports grew on average at 58 percent per year in 2000-03.

Table 25: Composition of 'most dynamic' EU-oriented exports and rates of growth in 2000-03 (in percent)

\begin{tabular}{|c|c|c|c|c|c|c|}
\hline & & & & & Total EU-exports & Average rate of growth \\
\hline & 2000 & 2001 & 2002 & 2003 & 2003 & per year in 2000-03 \\
\hline Natural Resource Intensive & 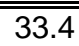 & 33.9 & 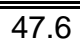 & 30.5 & 30.6 & 54.5 \\
\hline Unskilled Labor Intensive & 16.7 & 13.9 & 13.5 & 15.9 & 40.3 & 56.2 \\
\hline Capital Intensive & 42.0 & 45.4 & 33.3 & 47.0 & 16.0 & 62.6 \\
\hline Skilled Labor Intensive & 7.9 & 6.9 & 5.7 & 6.7 & 13.1 & 51.3 \\
\hline \multicolumn{7}{|l|}{ Memorandum: } \\
\hline Share in EU-oriented exports & 3.8 & 8.5 & 15.4 & 15.9 & 100 & 58.1 \\
\hline
\end{tabular}


Not all products among 141 high performers are new exports, although they appear to come from restructured production capacities. In fact, most of them were exported before 200003 and often enjoyed significant presence in EU markets as measured by shares in EU external import demand. All of them, however, saw their shares plunging in 1996-99 and subsequently fortunes reversed in 2000-03. While in 1997-98 four four-digit SITC products had the share in EU external imports exceeding 2 percent, their number fell to one in 1999-2000, and increased to 8 in 2001, 14 in 2002 and 15 in 2003. These were not tiny exports in terms of value. The number of products with the value of exports exceeding US\$ 5 million rose from between five and seven in 1996-2000 to 13 in 2001, 22 in 2002 and 32 in 2003.

How does the composition of these exports in terms of factor content intensities compare to the composition of Bulgaria's total EU-oriented exports in 2003? The most striking difference is much lower share of unskilled labor intensive products among 'fast growers' and a much larger share of capital intensive products. The differences are staggering especially for the latter accounting for almost half of fast growers in 2003. Among capital intensive products machinery (SITC 7) emerged as the major driver accounting for 36 percent of fast growers' EU-destined exports.

Hence, it appears that the process of industrial restructuring has been going on and only now begins to influence overall export performance. In line with trends observed in other CEEC10 economies, capital intensive products have been emerging as the levers of export growth.

\section{E. Factors content of EU-oriented exports and level of technology}

Examination of Bulgaria's export offer in terms of technologies embodied in Bulgaria's products exported to the EU provide further evidence pointing to, on the one hand, the dominance of low-tech labor intensive products and signs of ongoing modernization of Bulgaria's industrial base. We use a simple classification, developed by Landesman and Stehrer (2003), filtering Bulgaria's export oriented into three broad categories: (1) low technology and labor intensive activities, (2) resource intensive activities, and (3) medium- to high-technology production activities. In contrast to its earlier application (see Section 3.C), we include resource intensive products, and we do not restrict the analysis to manufactures but include all other productsindustrial and agricultural alike. Resource intensive sectors consist of manmade fibers, wood and wood products, coke, refined petroleum products and nuclear fuels, mineral products, and chemicals.

Table 26: Composition of exports by the type of technology involved in their production, their share and export specialization index and their changes in 1996-2003 (in percent)

\begin{tabular}{|c|c|c|c|c|c|c|c|c|c|c|c|}
\hline & 1996 & 1997 & 1998 & 1999 & 2000 & 2001 & 2002 & 2003 & \multirow{2}{*}{$\begin{array}{l}\text { Change } \\
\text { in } 2003\end{array}$} & \multirow{2}{*}{$\begin{array}{l}\text { Index, } 1999 \\
\text { 1996=100 }\end{array}$} & \multirow{2}{*}{$\begin{array}{l}\text { Index } 2003 \\
2000=100\end{array}$} \\
\hline \multicolumn{9}{|c|}{ Share in Bulgaria's EU-oriented exports } & & & \\
\hline Low-tech labor intensive & 40.9 & 41.6 & 43.8 & 46.4 & 39.9 & 45.2 & 47.5 & 444.8 & -5.8 & 113 & 112 \\
\hline Resource intensive & 36.9 & 37.7 & 35.9 & 31.0 & 37.8 & 30.8 & 25.3 & 26.1 & 3.2 & 84 & 69 \\
\hline Medium- to high tech & 13.5 & 11.2 & 12.6 & 16.0 & 13.9 & 14.4 & 17.8 & 19.1 & 7.2 & 119 & 137 \\
\hline \multicolumn{12}{|c|}{ Share in EU external imports } \\
\hline Low-tech labor intensive & 0.59 & 0.65 & 0.71 & 0.73 & 0.76 & 0.91 & 0.97 & 1.02 & 4. & 123 & 134 \\
\hline Resource inte & 0.68 & 0.73 & 0.69 & 0.58 & 0.76 & 0.70 & 0.60 & 0.68 & 13.1 & 85 & 89 \\
\hline Medium- to high tech & 0.33 & 0.27 & 0.28 & 0.35 & 0.31 & 0.34 & 0.42 & 0.44 & 5.7 & 106 & 144 \\
\hline \multicolumn{12}{|c|}{ Export Specialization in EU markets } \\
\hline Low-tech labor intensive & 2.06 & 2.14 & 2.28 & 2.62 & 2.57 & 2.80 & 2.81 & 2.74 & -2.5 & 128 & 106 \\
\hline Resource intensive & 2.35 & 2.40 & 2.21 & 2.07 & 2.58 & 2.14 & 1.73 & 1.82 & 5.4 & 88 & 71 \\
\hline Medium- to high tech & 0.09 & 0.08 & 0.09 & 0.10 & 0.09 & 0.11 & 0.15 & 0.16 & 13.3 & 102 & 182 \\
\hline
\end{tabular}

Source: Own calculations based on EU-15 trade data reported to the UN COMTRADE database.

As expected, the specialization profile in EU markets, as obtained through running the trade data through the above discussed "technology" filter, does not diverge overall from the export basket in terms of factor intensities. Its export basket embodies mainly resource and labor 
intensive activities, which clearly dominate accounting for around 80 percent of Bulgaria's EUoriented exports (Table 26 above).

Yet, a closer examination sheds new light on trends identified earlier providing an extra evidence supporting the observation about Bulgaria's exports moving to more value-added and technology intensive activities. Note first that medium to high technology products recorded the largest in terms of value in 2000-03. They also registered the largest gains in share in EU external imports as well as in export specialization, albeit the latter have a long way to dominance in Bulgaria's specialization profile.

\section{F. Concluding observations}

Bulgaria appears to have been losing features of its export performance that have set its patterns of specialization aside from other CEEC-9 transition economies since 1996. Empirical analysis in this section provides evidence in support of the following observations: First, while the 1996-2000 witnessed little or no gains in overall competitiveness of Bulgarian producers in world markets, except for clothing mainly in EU markets, there was a significant increase in the presence of Bulgarian exporters in the most recent period, especially in 2003.

Second, the gap between CEEC-8 economies and Bulgaria in terms of export performance and its factor embodiments appears to be closing, albeit slowly. The emergence of capital- and skilled labor-intensive products as drivers of Bulgaria's EU-oriented exports between 1994 and Bulgaria's second transformational recession in 1996-97 was not only in defiance of patterns observed in other CEEC-10 but also was the result of distortions imputed by economic regime overtaken by narrow private interests. Although in 1996-99 the situation reversed itself, i.e., while capital- and skilled-labor intensive products have replaced unskilled labor intensive products as drivers of CEEC-8 as well as Romania's exports, unskilled labor intensive products towered Bulgaria's exports.

Although this pattern of specialization largely continued through 2000-03, there are indications of the ongoing shift towards patterns typical of other CEEC-10. Among emerging fast growers, i.e., products whose exports growth exceeded annual changes in EU import demand by at least 30 percent in 2000-03, capital intensive products have stood out. In the same vein, the degree of processing embodied in Bulgaria's exports has been on the increase, with the share of manufactures in total exports rapidly growing and the share of traditional production inputs declining. Exports of clothing, although still accounting for around one-fourth of Bulgaria's total exports, are no longer the only bright spot in Bulgaria's overall export performance, as it was the case in 1996-99. Exports of electrical machinery have begun emerging as the top performers in world markets.

Hence, a shift, similar to that earlier observed in other CEEC-10 economies, towards gaining competitiveness in capital and skilled labor intensive products appears to be underway. It appears that the process of realignment in allocation of resources in response to economic opening has begun impacting Bulgaria's export basket. Capital and labor have been moving to more sophisticated and higher value added activities and more processed goods with higher content of capital and skilled labor have been expanding faster than traditional inputs and unskilled labor intensive products. The challenge for policy makers is to sustain this healthy transformation better reflecting Bulgaria's relative competitive strengths.

\section{Integration into EU production structures: participation in EU-driven value chains}

The combination of technology and business friendly and efficient services environment has spurred a new global division of labor. Its trademark is dividing up the value chain into smaller components and moving them to countries where their costs of production could be 
lower. Production fragmentation in vertically integrated sectors is behind 'producer-driven' network trade. It differs in several important respects from traditional, 'buyer-driven' global value chains. It includes two-way flows of parts and components across firms located in various countries for further processing and development. A historical example of production fragmentation at a regional level is the Canada-United States Automotive Products Agreement of 1965, which, followed by the significant reduction in trade barriers, led to an expansion of trade in auto parts (Jones et al. 2004).

International production and distribution networks, also known as global commodity chains resulting in production fragmentation due to dividing the value chain of production into smaller operations, refer to activities involved in the design, production and marketing of a product. One may distinguish between 'buyer-driven' and 'producer-driven' value chains. The former denotes the case of global buyers creating a supply-base upon which production and distribution systems are built without direct ownership. The latter refers to vertically integrated arrangements. To be sure, this classification does not exhaust all possible venues of participation in global networks.

'Buyer-driven' commodity chains tend to exist in industries in which large retailers, branded marketers and branded manufacturers play the pivotal roles in setting up decentralized production networks in a variety of exporting countries, typically in developing or transition economies. This pattern has become common in labor-intensive, consumer goods sectors, such as apparel, footwear, etc. Our focus will be on three buyer-driven chains: textiles and clothing (TC); footwear; and furniture. The latter differs especially from TC value chains, as it involves operations that tend to be more diversified and complex requiring larger local input of skills and investment in capital assets. Similarly to clothing and footwear, furniture producers operating in a global value chain supply products according to specification provided by large multinational retailers. They also tend to be locally owned, but the relationship between supplier and multinational retailer frequently reflect larger complexity of tasks involved. In consequence, their relationship is based on a more long-term mutual commitment, which is less sensitive to the rise in labor costs and creates more opportunities for spillovers.

'Producer-driven' commodity chains are those in which large multinational corporations play a central role in coordinating the production process. They are mainly present in capital- and skilled-labor-intensive industries such as automobiles, computers, semiconductors and heavy machinery. Automotive and information and communication technology (IR) represent the most dynamic 'producer-driven' networks. While outsourcing in clothing, footwear or furniture has rarely been accompanied by significant inflows of FDI, although there have been exceptions, the entry into supply chains of automotive and IT networks is almost inconceivable without MNCs bringing capital, technology and marketing. As MNCs drive trade in these two networks, it will be referred to as "MNC-driven" network trade. ${ }^{18}$

Network trade has been the driving force of CEEC-10 economies' integration into global markets. The most developed of them have moved through two stages. First, 'buyer-driven' network exports have been the first major vehicle linking them to external markets. The point of departure has been as a rule inward processing in relatively technologically simple and capital non-intensive activities such clothing often followed and/or accompanied in transition economies by footwear and furniture.

The second stage has been participation in 'producer-driven' networks. Engagement in global networks in electronics or automotive industry usually comes at higher stages of economic

\footnotetext{
${ }^{18}$ The empirically observed positive correlation between multinational activity and intra-industry trade would also clearly point in this direction (Markusen 1998).
} 
development. It marks moving to a new division of labor based on production fragmentation. As the experience from other countries indicates, foreign investments are crucial to overcome this barrier. The link between the FDI and network trade seems to be ubiquitous for 'producer-driven' network trade. Two largest recipients of FDI-the Czech Republic and Hungary-have been also the best performers in 'producer-driven' network exports. On the other hand, although participation in furniture or clothing global chains does not necessarily require foreign investments, it is often associated with FDI. A good example is Romania's clothing sector, characterized by much higher foreign penetration than in other CEECs (Hunya 2002, p. 391). A large number of small Italian firms appear to dominate both clothing and leather industries in Romania (Kaminski, Ng 2004).

This section examines Bulgaria's place in evolving division of labor driven regionally by EU Eastern Enlargement Project. It assesses participation of Bulgarian firms in global chains organized around the EU-15 but also increasingly encompassing some recent EU entrants, mainly Hungary and to a lesser extent the Czech Republic that are becoming regional intermediaries in 'producer-driven' networks (Kaminski 2005).

\section{A. Participation in 'buyer-driven' value chains: clothing, footwear and furniture}

Clothing and, to a lesser extent, footwear have been the quintessential engines of growth for many CEEC-10 during the initial stages of transition. They have accounted for a significant share of value added and manufacturing employment, with consequential implications for poverty reduction. With increasing wages in successful reformers, many of outward processing operations in the clothing sector have been shifting to economies less advanced in the transformation process to take advantage of lower labor costs in to other countries in Central and South East Europe through the 1990s. The dates when their share in exports of manufactures peaked indicates the end of TC operations as engines of export growth. For Bulgaria and Romania as well as other SEE-4 economies, their share peaked only in the second half of the 1990s and early 2000s (Table 27). In all of them, exports of other manufactures have begun outpacing TC exports.

Table 27: Share of clothing in exports of manufactured goods excluding chemicals in 1992-2002 (in percent)

\begin{tabular}{|l|c|ccc|c|}
\hline & $\begin{array}{c}\text { Peak } \\
\text { year }\end{array}$ & $\begin{array}{c}\text { Share in } \\
\text { peak year }\end{array}$ & $\begin{array}{c}\text { Share in 2003 } \\
\text { or latest available }\end{array}$ & $\begin{array}{c}\text { Index, 2003 } \\
\text { peak=100 }\end{array}$ & $\begin{array}{c}\text { Average annual growth rate } \\
1996-2003\end{array}$ \\
\hline \hline Hungary & 1992 & 21.2 & 4.1 & 20 & 3.8 \\
Slovenia & 1993 & 13.8 & 3.5 & 25 & -7.5 \\
Poland & 1993 & 18.9 & 5.2 & 27 & -1.9 \\
Czech Republic & 1994 & 3.8 & 1.8 & 46 & 2.2 \\
Estonia & 1995 & 14.1 & 7.3 & 52 & 8.4 \\
Slovak Republic & 1997 & 7.3 & 3.9 & 54 & 14.7 \\
\hline \hline Croatia & 1997 & 25.8 & 15.5 & 60 & -0.9 \\
Albania & 1998 & 48.5 & 41.1 & 85 & 17.2 \\
Serbia \& Montenegro & 1998 & 18.7 & 14.5 & 78 & -4.4 \\
Latvia & 1999 & 20.4 & 16.0 & 78 & 9.7 \\
Lithuania & 1999 & 27.7 & 16.6 & 60 & 12.0 \\
Romania & 1999 & 32.8 & 29.8 & 91 & 18.5 \\
Macedonia & 2002 & 46.4 & 44.9 & 97 & 7.3 \\
Bulgaria & $\mathbf{2 0 0 2}$ & $\mathbf{3 4 . 8}$ & $\mathbf{3 4 . 0}$ & $\mathbf{9 8}$ & $\mathbf{2 1 . 2}$ \\
\hline
\end{tabular}

Source: Own calculations based on national trade statistics reported to the UN COMTRADE database.

Bulgaria became part of TC value chains much later than other CEEC-10, but it has caught up very quickly. Since 1996 Bulgaria has been very successful in tapping opportunities offered by outward processing mostly by EU firms of garments. With the average annual rate of growth of 21 percent, it recorded the fastest growth over 1996-2003 among CEEC-10 and SEE-4 
economies. ${ }^{19}$ This was also the fastest growing value chain among buyer-driven chains, with its share in total EU-oriented exports increasing from 78 percent in 1996 to 83 percent in 2000. In 2001-03, exports of both footwear and furniture chain products and parts grew faster than TC exports. The share of TC in total 'buyer-driven' network exports fell to 80 percent in 2003, while that of footwear to 14 percent up from 12 percent in 2000 and that of furniture to 6 percent up from 5 percent.

Entry of Bulgarian firms into 'buyer-driven' value chains has been significantly delayed in comparison to other CEEC-10 economies and except for TC chain, no other chain has emerged as a lever of Bulgaria's export growth. In fact, until 2001 exports of both footwear and furniture chains remained stagnant. Exports of footwear grew in line with total EU-oriented exports, with their share in Bulgaria's exports at around 5 percent (Table 28). Furniture network had the strongest growth between 2001 and 2003, with the value of its exports almost doubling.

How competitive have producers from 'buyer-driven' networks been in EU markets? Exporters of products and parts of 'buyer-driven' chains have been competitive in EU markets, as their respective shares in EU external imports increased rather significantly especially in 2000-03 for furniture and footwear producers. Their share in EU external imports grew consistently through 1996-99 mainly because of impressive performance of TC network towering over exports from other 'buyer-driven' chains. While the growth in share of Bulgarian TC products in EU imports remained roughly the same of around 7-8 percent per year during both the 1996-99 stagnation and 2000-03 expansionary phases, exporters of products of other chains did not make any significant in-roads in EU markets in 1996-2000. The share of footwear in EU imports was in 200338 percent higher than in 2000 and that of furniture products 37 percent higher. In both networks, producers of parts have outperformed suppliers of final products in terms of gains in market share. The same applies to TC network, with textiles registering much stronger gain (95 percent) than clothing (25 percent over 2000). Exporters of parts saw their share increase 73 percent between 2001 and 2003 (Table 28).

The shift towards parts is indicative that Bulgaria ceases to be mostly an assembly shop for EU firms taking advantage of available cheap labor force. While without the survey of firms in sectors or access to input-output tables it is impossible to give an unambiguous answer to this assessment, an examination of trade data tabulated in Table 15 offers some clues. Developments within each chain suggest slightly different answers. While data point to the development of backward linkages in footwear and furniture chains, no clear conclusion can be drawn in reference to TC value chain.

The TC at first involves cut-make-trim (CMT) tasks, possibly followed by a move to FOB, i.e., firm providing the fabric itself and charging for the final garment rather than earning only a processing fee. The ability to shift to FOB critically depends on the price and quality of domestically available fabrics. Their absence weakens competitiveness of domestic producers. The TC trade data do not suggest the fall in import intensity, the share of imported fabrics in total TC exports, which usually accompanies the shift to FOB operations. Yet, it would be impossible to conclude that (a) there is shortage of domestically available high quality fabrics and (b) that simple CMT operations continue to expand in the Bulgarian garment sector. Consider the following: The importance of imported inputs for final exports, as measured by imports of textiles as percent of exports of clothing and textiles, slightly increased in TC chain from 50 percent in 2000-01 to 55 percent in 2002-03. While no firm conclusions can be drawn on the basis of such a crude measure, this may suggest lack of significant progress in the development of backward

\footnotetext{
${ }^{19}$ While negative growth rates of exports from Croatia were probably caused by the loss of competitiveness due to growing wages, the reasons for steeper contraction in exports from Serbia/Montenegro may relate to its troubled relations with the EU until 2001and adverse business climate.
} 
linkages. But this conclusion is tentative at best. This share is significantly lower than in Romanian TC chain (67 percent in 2002), although in the latter it has been on the decline. The increase in the share of textiles in TC exports, which, after the contraction from 16 percent in 1996 to 8 percent in 2000, strongly rebounded to 12 percent in 2003, suggests the availability of high quality fabrics in Bulgaria. Last but not least, imported fabrics may be used for producing more processed fabrics for exports.

Table 28: Trade with the EU in 'buyer-driven' chains in 1996-2003 (in millions of US dollars and percent)

\begin{tabular}{|c|c|c|c|c|c|c|c|c|c|}
\hline Product (SITC Revision 2) & 1996 & 1997 & 1998 & 1999 & 2000 & 2001 & 2002 & 2003 & $\begin{array}{l}\text { Change } \\
2003 \\
\text { over } 2001\end{array}$ \\
\hline $\begin{array}{l}\text { A. Textiles and Clothing (SITC } 65+8998 \text { and 84): } \\
\text { Total exports of Textiles \& Clothing (\$ million) }\end{array}$ & 471 & 557 & 686 & 697 & 793 & 997 & 993 & 1,309 & $31 \%$ \\
\hline Share of textiles in total T\&C exports (\%) & 15.5 & 14.4 & 12.8 & 9.8 & 8.0 & 8.7 & 12.2 & 12.0 & $38 \%$ \\
\hline Imports of textiles (\$ million) & 236 & 282 & 321 & 339 & 395 & 497 & 548 & 726 & $46 \%$ \\
\hline Share of textiles in imports of T\&C (\%) & 72 & 69.9 & 67.5 & 68.5 & 68.1 & 68.5 & 65.8 & 66.0 & $-4 \%$ \\
\hline $\begin{array}{l}\text { Imports of textiles as \% of exports of T\&C (\%) } \\
\text { Memo Items: }\end{array}$ & 50.2 & 50.6 & 46.8 & 48.7 & 49.7 & 49.8 & 55.2 & 55.4 & $11 \%$ \\
\hline Share of T\&C in Bulgaria's total exports (\%) & 21.4 & 23.1 & 27.0 & 29.3 & 27.9 & 32.0 & 30.2 & 30.5 & $-5 \%$ \\
\hline Share of EU in Bulgaria's total T\&C exports (\%) & 79.2 & 78.1 & 80.5 & 81.4 & 80.3 & 79.1 & 76.9 & 76.7 & $-3 \%$ \\
\hline & 0.74 & 0.84 & 0.98 & 1.01 & 1.14 & 1.41 & 1.35 & 1.49 & $6 \%$ \\
\hline of which: textile & 0.12 & 0.12 & 0.13 & 0.10 & 0.09 & 0.12 & 0.16 & 0.18 & $46 \%$ \\
\hline & 0.63 & 0.72 & 0.86 & 0.91 & 1.05 & 1.29 & 1.18 & 1.31 & $2 \%$ \\
\hline \multicolumn{10}{|l|}{ B. Footwear and parts (SITC 85 and 61} \\
\hline Total exports of Footwear \& Parts (\$ mill & 103 & 128 & 121 & 111 & 116 & 161 & 172 & 222 & $38 \%$ \\
\hline Shar & 41.3 & 39.4 & 37.7 & 38.8 & 43 & 43.1 & 48.9 & 45.4 & $5 \%$ \\
\hline & 36.0 & 39.6 & 37.5 & 39.6 & 43.4 & 61.2 & 56.9 & 75.0 & $23 \%$ \\
\hline & 76.2 & 74.5 & 74.4 & 80.4 & 85.7 & 89 & 87.5 & 87.3 & $-2 \%$ \\
\hline $\begin{array}{l}\text { Imports of parts as \% of exports of footwear \& parts (\%) } \\
\text { Memo Items: }\end{array}$ & 35.0 & 31.1 & 31.1 & 35.9 & 37.6 & 38 & 33.1 & 33.8 & $-11 \%$ \\
\hline Share of footwear \& parts in Bulgaria's total exports (\%) & 4.7 & 5.3 & 4.8 & 4.6 & 4.1 & 5.2 & 5.2 & 5.2 & $0 \%$ \\
\hline Share of EU in Bulgaria's exports of footwear \& parts (\%) & 92.9 & 91.8 & 91.5 & 93.6 & 92.4 & 90.7 & 88.1 & 90.2 & $-1 \%$ \\
\hline \multirow{3}{*}{$\begin{array}{r}\text { Share in EU external imports of footwear \& parts (in \%) } \\
\text { of which: parts } \\
\text { Footwear }\end{array}$} & 1.28 & 1.45 & 1.40 & 1.22 & 1.22 & 1.55 & 1.56 & 1.68 & $8 \%$ \\
\hline & 0.53 & 0.57 & 0.53 & 0.47 & 0.52 & 0.67 & 0.76 & 0.76 & $14 \%$ \\
\hline & 0.75 & 0.88 & 0.87 & 0.74 & 0.69 & 0.88 & 0.79 & 0.92 & $4 \%$ \\
\hline \multirow{10}{*}{$\begin{array}{l}\text { C. Furniture and parts } \\
\text { Total exports of Furniture \& Parts (\$ million) } \\
\text { Share of parts in total furniture \& parts exports (\%) } \\
\text { Imports of furniture parts (\$ million) } \\
\text { Share of parts in imports of furniture \& parts (\%) } \\
\text { Imports of parts as \% of exports of furniture \& parts (\%) } \\
\text { Memo Items: } \\
\text { Share of furniture \& parts in Bulgaria's total exports (\%) } \\
\text { Share of EU in Bulgaria's exports of furniture \& parts (\%) } \\
\text { Share in EU external imports of furniture \& parts (in \%) } \\
\text { of which: parts } \\
\text { final products }\end{array}$} & & & & & & & & & \\
\hline & $\begin{array}{l}28.7 \\
18.0\end{array}$ & $\begin{array}{l}30.8 \\
19.6\end{array}$ & $\begin{array}{l}32.8 \\
21.5\end{array}$ & $\begin{array}{l}44.3 \\
25.7\end{array}$ & $\begin{array}{l}47.6 \\
25.6\end{array}$ & $\begin{array}{l}53.8 \\
23.8\end{array}$ & $\begin{array}{l}71.4 \\
23.8\end{array}$ & $\begin{array}{r}100.4 \\
27.5\end{array}$ & $\begin{array}{l}86 \% \\
16 \%\end{array}$ \\
\hline & 5.9 & 5.6 & 7.4 & 7.6 & 6.1 & 7.8 & 7.9 & 11.9 & $54 \%$ \\
\hline & 20.7 & 22.9 & 26.1 & 28.2 & 22.3 & 27.0 & 26.6 & 29.9 & $11 \%$ \\
\hline & 20.7 & 18.1 & 22.6 & 17.0 & 12.8 & 14.4 & 11.0 & 11.9 & $-18 \%$ \\
\hline & 1.3 & 1.2 & & 1.86 & 1.67 & 1.73 & 2.17 & 2.34 & $36 \%$ \\
\hline & 76.7 & 78.2 & 75 & 73.7 & 69.3 & 72.8 & 69.7 & 69.7 & $-4 \%$ \\
\hline & 0.41 & 0.42 & 0.38 & 0.45 & 0.45 & 0.49 & 0.58 & 0.61 & $27 \%$ \\
\hline & 0.07 & 0.08 & 0.08 & 0.12 & 0.12 & 0.12 & 0.14 & 0.17 & $46 \%$ \\
\hline & 0.34 & 0.33 & 0.30 & 0.34 & 0.33 & 0.37 & 0.44 & 0.45 & $20 \%$ \\
\hline \multicolumn{10}{|l|}{ D. Total 'Buyer-Driven' value chains } \\
\hline & 27.4 & 29 & & 35.8 & 33.7 & 38.9 & 37.6 & 38.0 & $-2 \%$ \\
\hline & 1 & 80 & 81 & 82.4 & 81 & 80.2 & 77.8 & 77.8 & $-3 \%$ \\
\hline Share in EU external imports of furniture & 0.77 & 0.87 & 0.9 & 0.97 & 1.06 & 1.31 & 1.27 & 1.39 & $6 \%$ \\
\hline & 0.15 & 0.17 & 0.1 & 0.14 & 0.14 & 0.18 & 0.23 & 0.24 & $33 \%$ \\
\hline tinal produ & 0.61 & 0.70 & 0.80 & 0.83 & 0.92 & 1.13 & 1.04 & 1.14 & $1 \%$ \\
\hline
\end{tabular}

Source: Computations based on UN COMTRADE Statistics.

As for footwear and furniture, the ratio of imported parts to total exports of footwear chain products fell from 38 percent in 2000-01 to 34 percent in 2003 and in exports of furniture from 23 percent in 1998 to 12 percent in 2003. Since in both networks this was accompanied by a quicker growth in exports of parts than of final products, this suggests that Bulgarian producers of are firmly embedded in EU-driven footwear and furniture chains. This also may suggest the 
emergence of backward linkages replacing imports with parts domestically produced. Both developments have positive spillovers.

The shift towards specialization in furniture parts is indicative of Bulgaria's overall progress in industrial restructuring following the pattern of earlier and more consistent reformers. Consider that while in 1995 only Slovenia, one of the most industrialized countries among CEEC-10 and important supplier to EU furniture producers already in the 1980s and to a lesser extent Hungary specialized in furniture parts, the situation changed already by 1999. For most CEEC-10 economies (except Latvia, Lithuania, Slovakia), exports of parts increased more than exports of final products in 1999-2003 (Table 29). Furniture parts have also become the driver of furniture network exports for most countries including most recently Bulgaria.

Table 29: Bulgaria's involvement in furniture network in comparative perspective in 1996, 1999 and 2003

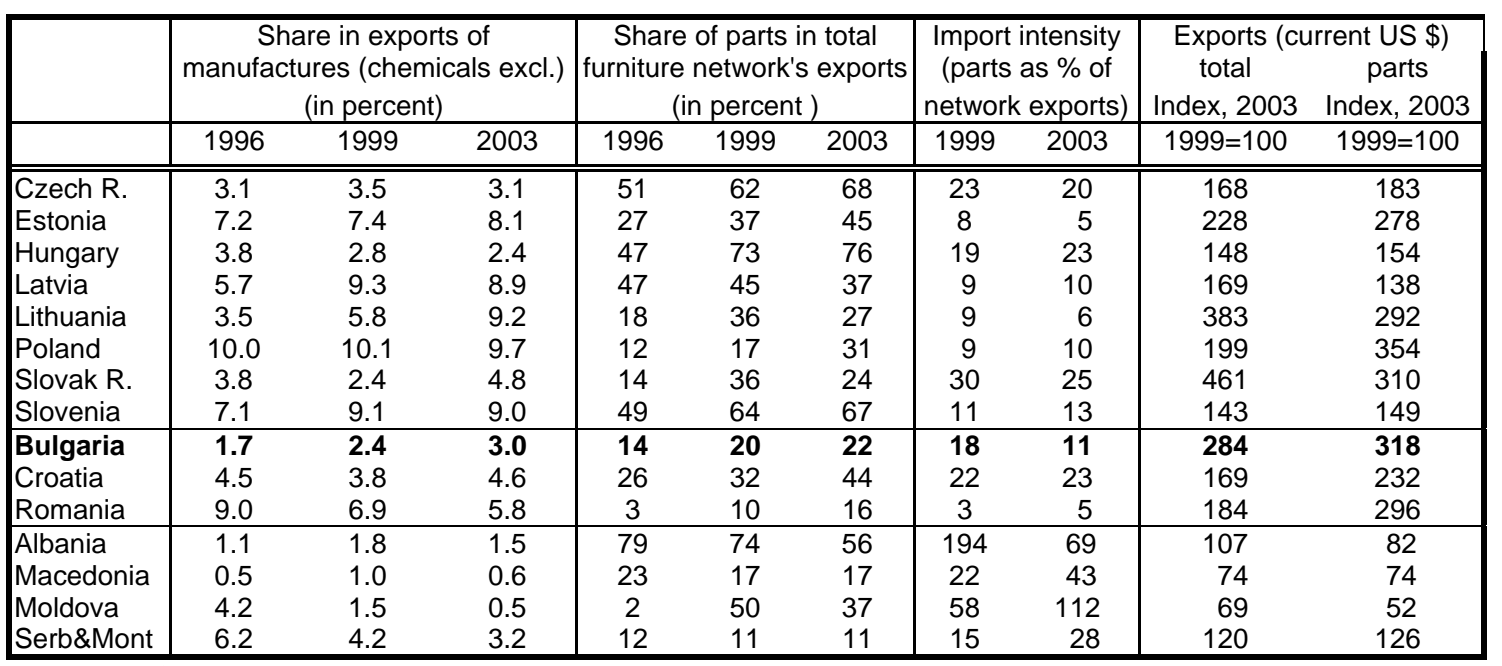

Note: For Serbia and Montenegro the most recent data available are for 2002.

Source: Computations based on UN COMTRADE Statistics.

Although the share of furniture network in Bulgaria's exports of manufactured goods, excluding chemicals, remains low, it almost doubled between 1996 and 2003. Moreover, it is low only by standards of CEEC-8 and Romania but not in comparison to SEE economies except Serbia and Montenegro. However, in the latter, these exports have been falling since 1996.

In all, developments in trade of 'buyer-driven' value chains seem to support the following observations: Respective industrial sectors in Bulgaria are not enclaves, but appear to be soundly immersed in the domestic economy. All of them have been very competitive in EU markets indicating significant progress in industrial restructuring. They have become part of global value chains, organized mainly by EU firms.

\section{B. 'Producer-driven' chains: automotive and information technology networks}

Despite huge differences, both ICT (information communication technology) and automotive sectors share an important characteristic; under the pressure of technological change released by Information Revolution "one stop shop" industrial structures have practically disappeared. Miniaturization, exponential growth in information processing and storage capacities combined with integration of Internet and imaging technologies have been the major driving forces behind transformation of both auto industry and ICT sectors worldwide over the last two decades. While several large MNCs coordinating production and marketing activities across the globe have traditionally dominated both sectors, MNCs in both of them have undergone dramatic change over the past two decades. Their common denominator has been 
either the disappearance or dramatic restructuring of global and vertically integrated firms. Thanks to new Internet technologies making possible to trace parts and components moving through chains of production spread over several countries and continents, vertically integrate firms have been replaced by supply chain structures connected through complex and borderless supply chains. These chains include not only product manufacturing but also the front-end customer contact and support services. They usually consist of several layers including parent companies, subsidiaries and subcontractors.

Until recently Bulgaria had remained outside the EU-based ‘producer-driven' networks. But in 2001-03 there were significant changes indicating entry of Bulgarian producers into supply chains of both networks. Although Bulgaria inherited industrial structure favoring specialization in ICT products rather then automotive ones, ${ }^{20}$ automotive sectors accounted in 1996 for 85 percent of total exports of producer-driven networks. ICT networks' exports emerged as dominant in Bulgaria producer-driven networks' exports first by default, i.e., automotive exports were falling faster than those of ICT products were until 2000, and subsequently thanks to stronger growth. Exports of ICT networks continued falling until 1999 and subsequently strongly rebounded (Table 30). So did exports automotive network, although they remained below their value in 1996.

Table 30: Total exports of producer-driven networks in 1996-2003 (in millions of US dollars)

\begin{tabular}{|c|c|c|c|c|c|c|c|c|}
\hline & 1996 & 1997 & 1998 & 1999 & 2000 & 2001 & 2002 & 2003 \\
\hline & \multicolumn{8}{|c|}{ (in millions of US dollars) } \\
\hline Exports of ICT Network products (in million of US dollars & 20.6 & 19.8 & 14.2 & 13.3 & 16.7 & 21.4 & 27.1 & 45.5 \\
\hline Exports of Automotive Network & 113.6 & 79.7 & 61.6 & 67.8 & 40.4 & 45.5 & 48.4 & 61.8 \\
\hline Total & 134.2 & 99.5 & 75.8 & 81.1 & 57.1 & 66.9 & 75.5 & 107.3 \\
\hline Memorandum: & \multicolumn{8}{|c|}{ (in percent) } \\
\hline Share of IT network in total producer networks' exports & 15.3 & 19.9 & 18.7 & 16.3 & 29.2 & 31.9 & 35.9 & 42.4 \\
\hline Share of the EU-25 & 51.0 & 44.6 & 57.4 & 65.0 & 58.3 & 56.8 & 46.4 & 66.4 \\
\hline of which: CEEC-8 & 14.4 & 17.1 & 14.7 & 9.9 & 9.6 & 8.5 & 6.5 & 7.5 \\
\hline Share of ROW & 34.5 & 38.3 & 27.9 & 25.0 & 32.1 & 34.6 & 47.1 & 26.1 \\
\hline
\end{tabular}

Source: Computations based on UN COMTRADE Statistics.

Post-1999 developments in Bulgaria's trade in producer network products flag its return to trends prevailing in other CEEC-10 economies and worldwide. First, in line with worldwide trends, Bulgaria's trade in ICT network products has displayed much stronger dynamics than that in automotive network. While the value of automotive exports stood still in 2003 at 54 percent of its peak level in 1996, but 50 percent above this level in 2000, the value of ICT exports was more than twice higher than in 1996 and more than three times higher than in 1999 (Table 30).

Second, Bulgarian firms have become increasingly integrated into EU-based networks of production and distribution but only during the 2000-03 period. Indeed, its earlier geographical patterns suggested continuation of former CMEA links even during the initial stages of transition in 1991-95, which, however, collapsed once reforms would begin taking hold in CIS economies. The emergence of hard-budget constraint and the shift in demand towards more sophisticated products crowded out Bulgarian suppliers. CIS imports accounted for 45 percent of Bulgarian exports of ICT network products in 1996, while the EU-15 together with CEEC-9 took only 28 percent of them. Their aggregate share rose to 60 percent in 1999, with the value of Bulgarian exports around one-third higher than in 1996. In contrast, CIS-oriented exports collapsed in 1999.

\footnotetext{
${ }^{20}$ In 1990 Bulgaria had a less developed automotive sector than in former Czechoslovakia or Poland, but its electrical equipment sector - one of the major players in ICT network trade-was as developed as that in Hungary. But while its share in total manufacturing output in 1989 was 8 percent in both Bulgaria and Hungary, a decade later its share fell to 4 percent in Bulgarian output and rose to 24 percent in Hungary (Szanyi 2004).
} 
So did ICT total exports falling from US\$ 21 million in 1996 to US\$ 13 million or by US\$ 8 million, which is precisely the amount of the contraction in CIS-destined exports. Similar geographic reorientation can be discerned in automotive network trade, with the recovery in exports mainly due to the increase in EU and CEEC import demand (Table 31).

Table 31: Trade with the EU in 'producer-driven' chains in 1996-2003 (in millions of US dollars and percent)

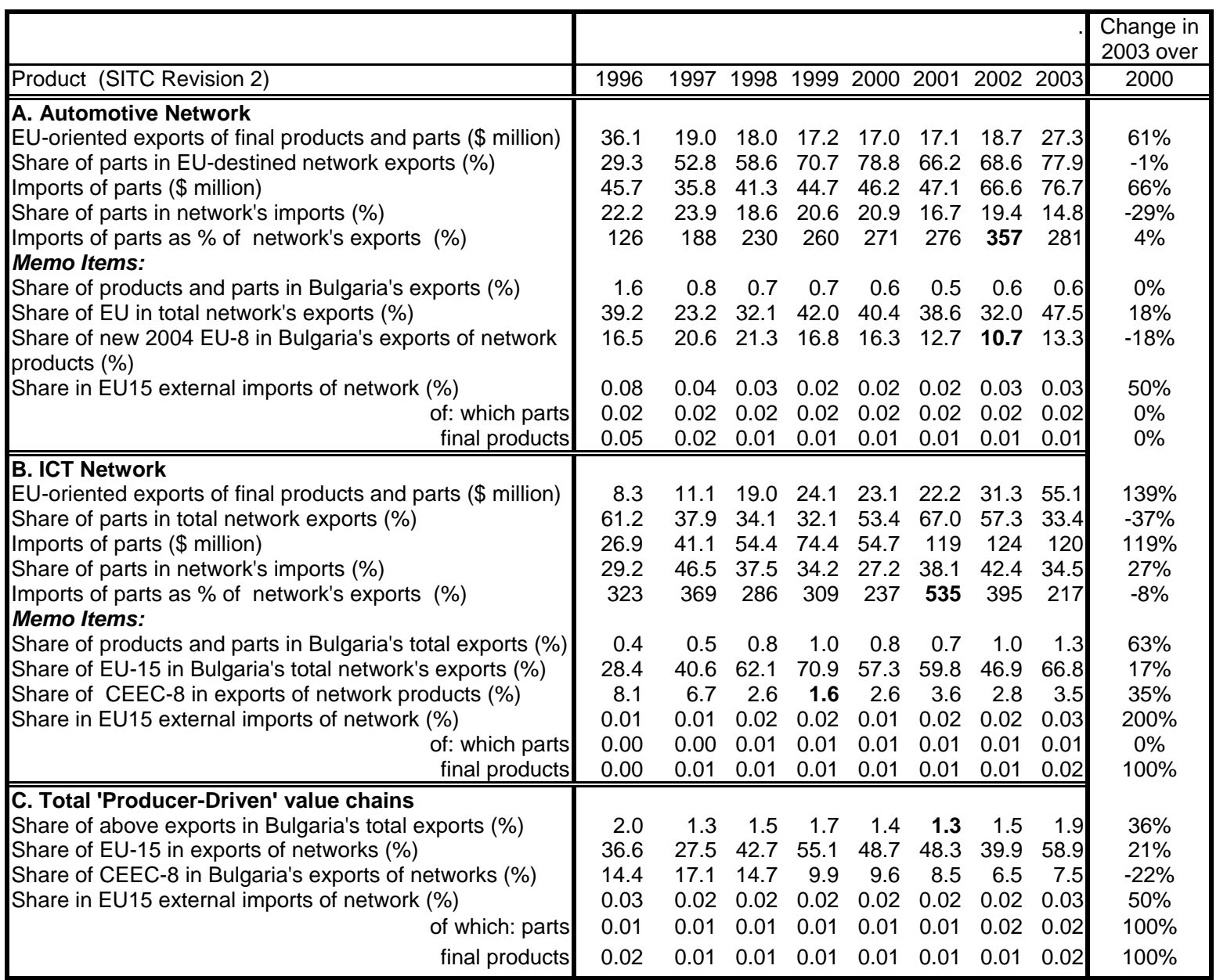

Source: Computations based on UN COMTRADE Statistics.

Third, in line with trends observed in other CEEC-10 economies (Kaminski 2004), there has been a shift towards specialization in automotive parts and ICT final products. Exports of the latter practically disappeared. While exports of motor vehicles accounted for 15 percent of automotive network's EU-destined sales in 1996, this share fell to 2 percent in 2003. On the other hand, the share of other parts and accessories (SITC 7849) increased from 5 percent to 15 percent over this period. Exports of parts to EU-15 and CEEC-8 markets have driven the growth in automotive network exports in 2002-03. The share of parts increased from 69 percent in 2002 to 78 percent in 2003 and the aggregate share of EU-15+CEEC-8 grew from 43 percent to 61 percent of total automotive network exports in this period indicating entry of some Bulgarian firms into 'pan-European' chains of supply.

While expanding demand in both EU-15 and CEEC-8 markets accounted for the 187 percent increase in total ICT network's exports in 2003, final products have become the major drivers of network's exports. Their share in total network's exports increased from 45 percent in 
2001 to 69 percent and in EU-oriented exports, accounting for 67 percent of Bulgaria's ICT exports, from 33 percent in 2001 to 66 percent in 2003. More significantly, there was a huge change in the composition of ICT EU-oriented exports: three four-digit SITC sectorsradiotelegraphic/ radiotelephonic products (7643), telecommunications equipment (7648), ${ }^{21}$ and parts of apparatus-now accounting for three-fourth of ICT exports contributed only 33 percent in 1999.

Last but not least, while import intensities of both networks remain very high indicating lack of significant assembly operations, they began falling in 2002-03. Based on network trade intensities of CEEC-10 that successfully have entered into supply chains, the value of the share of imports of parts in network's exports of parts and final products below 100 percent suggests significant involvement in division of labor based on production fragmentation.

Hence, despite a strong rebound and signs of entry of some firms, Bulgarian producers remain marginal suppliers in global 'producer-driven' networks. The share of networks' products and parts in Bulgarian total exports remains low and reached its peak 1996 level only in 2003. Despite significant gains in EU markets, their shares in EU imports of both networks' products are well beyond the share of total Bulgarian exports in total EU external imports.

\section{Bulgaria's producer-driven network trade in regional perspective}

Hence, Bulgaria has a long way to catch up with most other CEEC-10 in terms of participation in 'producer-driven' network-based trade. The share of 'producer-driven' network products in total exports of manufactured goods, excluding chemicals, in 2003 puts it on a par with Latvia, and except for Serbia and Montenegro is much higher than in SEE-3 economies. It is, however, much lower than in Romania (Table 32).

Table 32: Features of 'producer-driven' network trade of CEEC-10 and SEE-5 economies in 1996, 1999 and 2003 (in percent)

\begin{tabular}{|c|c|c|c|c|c|c|c|c|c|c|c|}
\hline & \multirow{2}{*}{\multicolumn{3}{|c|}{$\begin{array}{c}\text { Share in exports of manuf. } \\
\text { (chemicals excl.) } \\
\text { (in percent) }\end{array}$}} & \multirow{2}{*}{\multicolumn{2}{|c|}{$\begin{array}{l}\text { Exports (current US\$) } \\
\text { total parts }\end{array}$}} & \multicolumn{4}{|c|}{ Share of parts in exports of } & \multirow{2}{*}{\multicolumn{2}{|c|}{$\begin{array}{c}\text { Share of ICT network } \\
\text { exports in 'producer- } \\
\text { driven' exports }\end{array}$}} \\
\hline & & & & & & \multicolumn{2}{|c|}{ auto network } & \multicolumn{2}{|c|}{ ICT network } & & \\
\hline & 1996 & 1999 & 2003 & $2003-00$ & $2000-03$ & 1999 & 2003 & 1999 & 2003 & 1999 & 2003 \\
\hline Czech R. & 18 & 24 & 34 & 22 & 21 & 47 & 57 & 56 & 26 & 13 & 36 \\
\hline Estonia & 22 & 28 & 30 & 1 & 16 & 52 & 45 & 58 & 54 & 80 & 72 \\
\hline Hungary & 13 & 52 & 54 & 11 & 10 & 71 & 79 & 30 & 21 & 52 & 58 \\
\hline Latvia & 7 & 3 & 5 & 27 & 13 & 62 & 56 & 57 & 25 & 58 & 61 \\
\hline Lithuania & 24 & 14 & 19 & 24 & 14 & 28 & 14 & 73 & 73 & 57 & 41 \\
\hline Poland & 13 & 19 & 26 & 16 & 22 & 41 & 66 & 40 & 42 & 30 & 22 \\
\hline Slovak R. & 19 & 30 & 41 & 25 & 35 & 30 & 37 & 46 & 44 & 14 & 12 \\
\hline Slovenia & 21 & 21 & 22 & 10 & 14 & 37 & 47 & 35 & 25 & 9 & 12 \\
\hline Bulgaria & 8 & 5 & 4 & 24 & 24 & 66 & 60 & 49 & 41 & 28 & 64 \\
\hline Croatia & 7 & 5 & 8 & 16 & 14 & 96 & 84 & 37 & 49 & 33 & 61 \\
\hline Romania & 4 & 6 & 10 & 14 & 10 & 83 & 89 & 78 & 19 & 42 & 43 \\
\hline Albania & 0 & 3 & 2 & 41 & 97 & 21 & 73 & 10 & 54 & 47 & 57 \\
\hline Macedonia & 3 & 3 & 2 & 2 & 2 & 70 & 86 & 26 & 63 & 7 & 14 \\
\hline Moldova & 12 & 5 & 3 & 11 & 13 & 16 & 34 & 17 & 36 & 67 & 29 \\
\hline Serbia \& Mont & 10 & 13 & 11 & 10 & 14 & 80 & 85 & 46 & 34 & 3 & 9 \\
\hline
\end{tabular}

Note: For Serbia and Montenegro the most recent data available are for 2002.

Source: Computations based on UN COMTRADE Statistics.

Bulgaria fits neatly into two different patterns of specialization that appear to have been emerging in Central Europe since 2000. First, like most CEEC-10 economies that 'plugged-in' automotive networks, it has been moving towards specialization in automotive parts. While the share of parts in Bulgarian automotive exports was 66 percent in 1999, it fell to 44 percent in

\footnotetext{
${ }^{21}$ See Table 17 above on emerging top performers of electro-engineering industry.
} 
2000 and continued its upward movement through 2001-03. This was not the case of only two other exceptions to the general trend of increasing significance of parts-Latvia and Lithuania. The share of parts was consistently falling through 1999-03 in spite of a 20 percent average annual growth per year over 2000-03. Exports of final products simply grew faster.

Second, like most other CEEC-10 and SEE-participants of ICT networks, Bulgarian firms have been shifting towards specializing mostly in assembly operations. For most of them, the share of final products in ICT exports has significantly increased indicating the shift towards final production. Countries that succeeded in expanding exports of final products have also increased imports of IT parts. So has Bulgaria, which provides indications of the emergence of similar pattern of specialization in assembly operations. On the other hand, countries whose firms remain mostly outside ICT supply chains, i.e., from Albania, Croatia, and Macedonia, tend to produce parts rather than final products.

D. Other forms of outsourcing: exports of parts and other engineering products together with parts

The 'producer-driven' network analysis, confined to immediate inputs and final products of IT and automotive products, does not capture all intra-product trade. Some additional insights into developments in this trade can be obtained by examining specialization patterns in Bulgaria's trade with the EU in parts and engineering intermediate and final products not covered by network trade analysis. The list of products includes two groups: products defined explicitly as parts in four-digit SITC 7. Rev. 2 and SITC 8 (e.g., parts of clocks, cameras, and other optical equipment) hereafter referred to as 'other parts;' and 'other parts and products' including also machinery equipment products together with respective parts (e.g., hydraulic motors and parts, electrothermic appliances and parts).

How does Bulgaria score on this count? Two observations can be derived from data reported in Table 33. First, EU-oriented exports of these products have recorded strong and steady growth since 1997. The value of exports of parts not covered by network analysis increased 4.2 times between 1997 and 2003; they grew at an average compound rate of 24 percent per year over this period; and their share in EU external imports increased 3.4 times from 0.08 percent to 0.26 percent. If anything, this indicates the emergence of well-established commercial relations based on a stable participation in outsourcing by EU firms.

Table 33: Exports of parts and other engineering products and their share in EU external imports and Bulgaria's EU-oriented exports in 1996-2003 (in millions of US dollars and percent)

\begin{tabular}{|l|rrrrrrrr|c|}
\hline & 1996 & 1997 & 1998 & 1999 & 2000 & 2001 & 2002 & 2003 & $\begin{array}{c}\text { Change 2003 } \\
\text { over 2001 }\end{array}$ \\
\hline \hline Parts not covered by networks & 26.8 & 26.0 & 33.4 & 44.1 & 50.7 & 60.7 & 79.6 & 110.2 & $82 \%$ \\
Other engineering products and parts & 36.1 & 35.5 & 44.4 & 46.2 & 47.9 & 61.5 & 88.7 & 118.5 & $93 \%$ \\
\hline TOTAL ABOVE & 62.9 & 61.5 & 77.8 & 90.3 & 98.6 & 122.2 & 168.3 & 228.7 & $87 \%$ \\
\hline Imports of parts as percent of exports & 130 & 117 & 117 & 110 & 99 & 100 & 82 & 87 & $-13 \%$ \\
Share in EU external imports & $0.09 \%$ & $0.09 \%$ & $0.09 \%$ & $0.12 \%$ & $0.13 \%$ & $0.17 \%$ & $0.24 \%$ & $0.29 \%$ & $75 \%$ \\
Share in Bulgaria's EU-oriented exports & $2.9 \%$ & $2.6 \%$ & $3.1 \%$ & $3.8 \%$ & $3.5 \%$ & $3.9 \%$ & $5.1 \%$ & $5.4 \%$ & $37 \%$ \\
\hline
\end{tabular}

Source: Derived from EU trade data as reported to the UN COMTRADE database.

Second, the 2001-03 period witnessed significant acceleration of exports of both parts and other engineering products together with parts. This has not been because of appreciation of Euro vis-à-vis US dollar, as the increase in the value of exports of 87 percent in 2003 over 2001 accompanied a similar increase in Bulgaria's share in EU-external imports increasing 75 percent over this time. These products have driven the recent expansion in Bulgaria's EU-oriented exports, as their share in Bulgaria's exports increased from 3.7 percent in 2000-01 to 5.4 percent in 2003. 
While it may be premature to make predictions, developments in this trade may indicate the future pattern of Bulgaria's firms' integration into EU and global markets-integration going beyond ICT and automotive networks but still involving sophisticated engineering products and stable commercial relations with major world producers.

\section{E. Concluding observations}

Although Bulgarian firms' involvement in EU-based 'buyer-driven' global value chains still towers over 'producer-driven' networks and engineering products covered by EUoutsourcing, there are clear signs of ongoing transformation as revealed in Bulgaria's export basket. Bulgarian exports related to participation in global value chains account now for almost half of EU-oriented exports up from around one-third in 1996-97 (Table 34). 'Buyer-driven' exports accounted for 84 percent of these exports in 2003 down from an average of 88 percent in 1997-2001. This share fell mainly due to the expansion in exports of other parts and engineering products.

Table 34: Composition of EU-oriented exports of network products and other parts in 1996-2003 (in percent)

\begin{tabular}{|c|c|c|c|c|c|c|c|c|}
\hline & 1996 & 1997 & 1998 & 1999 & 2000 & 2001 & 2002 & 2003 \\
\hline Buyer-driven' networks & 84.9 & 88.6 & 88.0 & 86.6 & 87.3 & 88.2 & 85.0 & 84.0 \\
\hline of which: TC & 66.3 & 69.0 & 71.9 & 70.8 & 72.4 & 72.6 & 68.3 & 67.4 \\
\hline Producer-driven' networks & 6.3 & 3.7 & 3.9 & 4.2 & 3.7 & 2.9 & 3.4 & 4.2 \\
\hline of which: ICT & 1.2 & 1.4 & 2.0 & 2.4 & 2.1 & 1.6 & 2.2 & 2.8 \\
\hline Other parts and engineering products & 8.9 & 7.6 & 8.1 & 9.2 & 9.0 & 8.9 & 11.6 & 11.8 \\
\hline $\begin{array}{l}\text { Memorandum: Share in Bulgaria's EU- } \\
\text { oriented exports }\end{array}$ & 32.2 & 33.5 & 37.6 & 41.4 & 38.6 & 44.0 & 44.2 & 45.5 \\
\hline
\end{tabular}

Source: Derived from EU trade data as reported to the UN COMTRADE database.

Although exports from 'buyer-driven' chains continued to grow faster than total EUoriented exports in both 1996-99 and 2000-03, two significant changes have been occurring. First, textiles and clothing ceased to be the levers of 'buyer-driven' exports in 2000-03, although their export growth-driven increasingly by textiles-has remained impressive at an average annual growth rate of 13 percent. Second, furniture was the most dynamic export in 2002-03. The share of T\&C products in 'buyer-driven' network exports fell from 82 percent in 1998-2001 to 80 percent in 2002-03 due to the surge in exports of furniture network products in 2002 and 2003. The share of furniture exports in total 'buyer-driven' networks' exports grew from 4 percent in 1997-2001 to 6 percent in 2002-03.

Until recently Bulgaria had remained outside the EU-based 'producer-driven' networks. But in 2001-03 there were significant changes indicating entry of Bulgarian producers into supply chains of both networks. Bulgaria inherited industrial structure favoring specialization in ICT products rather then automotive ones, ${ }^{22}$ yet automotive sectors accounted in 1996 for 85 percent of total exports of producer-driven networks. ICT networks' exports emerged as dominant in Bulgaria producer-driven networks' exports first by default, i.e., automotive exports were falling faster than those of ICT products were until 2000, and subsequently because of stronger growth. Exports of ICT networks continued falling until 1999.

In all, the ongoing shift towards furniture (or more exactly furniture parts) within 'buyerdriven' networks' exports, towards ICT final products and automotive parts within 'producer-

\footnotetext{
${ }^{22}$ In 1990 Bulgaria had a less developed automotive sector than in former Czechoslovakia or Poland, but its electrical equipment sector - one of the major players in ICT network trade-was as developed as that in Hungary. But while its share in total manufacturing output in 1989 was 8 percent in both Bulgaria and Hungary, a decade later its share fell to 4 percent in Bulgarian output and rose to 24 percent in Hungary (Szanyi 2004).
} 
driven' exports and strong expansion of exports of other parts and engineering products point to significant progress in industrial restructuring and ensuing gains in competitiveness.

\section{Foreign Direct Investment and Trade}

The empirical evidence on links between FDI and trade point not only to the complementary relationship between FDI and exports ${ }^{23}$ but also to increasingly stronger links due to the growing fragmentation of production combined with the creation of distribution networks spanning across continents. Global diffusion of productive activity leads to an increased international trade in both final goods and parts and components. Thus, about one-third of world trade consists of intra-firm trade, that is trade among various parts of a single corporation, and the importance of intra-firm trade has been growing over time. Estimates also suggest that about twothirds of world trade in the latter half of the 1990s involved multinational corporations, including both intra-firm trade and arms-length transactions (UNCTAD 2002, p. 153). In consequence, the issue has become where firms locate their value added activities rather than whether FDI leads to trade or the other way around.

\section{A. Why limited impact in the 1990s?}

For Bulgaria, throughout most of the 1990s, the issue of links of FDI with trade was of little relevance for four reasons. First, Bulgaria-because of the combination of moratorium on private debt and rescheduling until the 1994 Club of London agreement resolved the rescheduling issue and unreformed economic regime-was not a significant recipient of FDI until 1997. In this year alone, the value of FDI of US\$ 537 was 47 percent above the cumulative inflows in 1990-96, which on average amounted to US\$ 68 per capita (Table 35). In all, 78 percent of cumulative FDI inflows over 1990-1999 came in 1997-99. Although FDI were on average above five percent of Bulgaria's FDI in 1997-99, given lead times and their concentration in nontradables, they had limited impact on trade in this period.

Table 35: FDI inflows to Bulgaria and CEEC-10 countries in 1991-96, 1997-1999 and 2000-2003

\begin{tabular}{|c|c|c|c|c|c|c|c|c|c|c|c|c|}
\hline & \multicolumn{3}{|c|}{$\begin{array}{l}\text { Average FDI (in millions } \\
\text { of US dollars }\end{array}$} & \multicolumn{3}{|c|}{$\begin{array}{l}\text { Average FDI per } \\
\text { capita (in US } \\
\text { dollars) }\end{array}$} & \multicolumn{3}{|c|}{$\begin{array}{l}\text { FDI as a percent of } \\
\text { average GDP in }\end{array}$} & \multicolumn{3}{|c|}{$\begin{array}{l}\text { Cumulative FDI over 1991-2003 in } \\
\text { terms of }\end{array}$} \\
\hline & $\begin{array}{c}1991- \\
96\end{array}$ & $\begin{array}{c}1997- \\
99\end{array}$ & $\begin{array}{c}2000- \\
03\end{array}$ & $\begin{array}{c}1991- \\
96\end{array}$ & $\begin{array}{c}1997- \\
99\end{array}$ & $\begin{array}{c}2000 \\
-03\end{array}$ & $\begin{array}{c}1991- \\
96\end{array}$ & $\begin{array}{c}1997 \\
-99\end{array}$ & $\begin{array}{c}2000 \\
-03\end{array}$ & $\begin{array}{l}\text { Total (mln } \\
\text { of \$ dollars) }\end{array}$ & $\begin{array}{l}\text { Per capita } \\
\text { in US\$ }\end{array}$ & $\begin{array}{l}\text { cumulative } \\
\text { GDP }\end{array}$ \\
\hline Bulgaria & 68 & 620 & 1,205 & 9 & 79 & 154 & 0.6 & 5.2 & 7.8 & 7,129 & 911 & 3.9 \\
\hline Czech Republic & 1,020 & 3,772 & 6,197 & 100 & 370 & 607 & 2.5 & 6.9 & 9.4 & 42,640 & 4,180 & 6.4 \\
\hline Estonia & 132 & 339 & 477 & 98 & 251 & 354 & 3.2 & 6.8 & 7.4 & 3,735 & 2,767 & 5.7 \\
\hline Hungary & 2,191 & 1,930 & 1,511 & 216 & 191 & 149 & 5.5 & 4.1 & 2.5 & 24,772 & 2,448 & 3.9 \\
\hline Latvia & 117 & 406 & 327 & 50 & 175 & 141 & 2.2 & 6.6 & 4.0 & 3,323 & 1,432 & 4.0 \\
\hline Lithuania & 32 & 580 & 530 & 9 & 168 & 153 & 0.4 & 5.5 & 3.8 & 4,137 & 1,198 & 3.1 \\
\hline Poland & 1,644 & 4,880 & 5,799 & 43 & 128 & 152 & 1.6 & 3.0 & 3.1 & 50,551 & 1,323 & 2.7 \\
\hline Romania & 194 & 1,432 & 1,122 & 9 & 65 & 51 & 0.6 & 3.8 & 2.4 & 10,017 & 451 & 2.1 \\
\hline Slovakia & 153 & 386 & 2,475 & 29 & 72 & 460 & 1.0 & 1.8 & 10.2 & 12,104 & 2,249 & 4.8 \\
\hline Slovenia & 96 & 241 & 1,107 & 49 & 123 & 564 & 0.6 & 1.3 & 5.1 & 5,817 & 2,962 & 2.5 \\
\hline $\begin{array}{l}\text { TOTAL or } \\
\text { average } \\
\text { Memorandum: B }\end{array}$ & 5,616 & 14,588 & 20,749 & 55 & 142 & 201 & 2.1 & 3.9 & 4.6 & 164,225 & 1,594 & 3.6 \\
\hline $\begin{array}{l}\text { Percent of the } \\
\text { average or total }\end{array}$ & 1.2 & 4.3 & 5.8 & 15.9 & 56.0 & 76.4 & 30.4 & 133 & 170 & 4.3 & 57.2 & 108 \\
\hline
\end{tabular}
and World Development Indicators 2003.

Second, one has significant doubts whether foreign trade considerations were behind significant portion of FDI inflows especially in 1998-99. The share of FDI originating in highly developed OECD economies fell to 56 percent and 50 percent of total annual inflows in this

\footnotetext{
${ }^{23}$ See Blonigen (2001) for a literature review.
} 
period, whereas the share of Cyprus rose to 24 percent and 20 percent in respective years. Cyprus was by far the largest investor in 1998 (US\$ 131 million), with the US distant second (US\$ 50 million). In 1999 investments originating in Cyprus amounted to US\$ 162 million well above the second Holland with US\$ 106 million and third Russia with US\$ 100 million. On the one hand, this was a positive development signaling the reversal of capital flight in response to the improvements in business climate. On the other hand, however, considering the local expertise of investors, these were probably mostly investments targeting domestic markets or already well established external ones.

Third, FDI going to sectors producing tradable goods (agriculture, mining and manufacturing) accounted for a relatively low share of the total FDI. In terms of FDI cumulative over 1998-2003 sectors producing tradable goods attracted 26 percent of total FDI inflows in this period (Table 36). In contrast, manufacturing alone accounted for almost half of FDI inflows to Czech Republic and Slovakia. Services sectors have attracted almost two thirds of total inflows. The most prominent among them was the banking sector almost completely wiped out in years preceding the outbreak of the financial crisis in 1996.

Table 36: Sectoral composition of FDI flows in 1998-2003 (in percent)

\begin{tabular}{|c|c|c|c|c|c|c|c|c|}
\hline & \multirow[b]{2}{*}{1998} & \multirow[b]{2}{*}{1999} & \multirow[b]{2}{*}{2000} & \multirow[b]{2}{*}{2001} & \multirow[b]{2}{*}{2002} & \multirow[b]{2}{*}{2003} & \multicolumn{2}{|c|}{ Cumulative } \\
\hline & & & & & & & 1998-2003 & 2000-2003 \\
\hline Tradable goods sectors & 35.3 & 53.7 & 19.9 & 31.7 & 9.7 & 18.4 & 26.1 & 19.5 \\
\hline Of which: manufacturing & 34.1 & 53.5 & 17.9 & 31.0 & 8.4 & 18.2 & 25.3 & 18.5 \\
\hline Services: & 58.4 & 37.7 & 72.5 & 60.8 & 72.6 & 70.2 & 63.6 & 69.4 \\
\hline Of which financial sector & 28.0 & 11.9 & 44.9 & 15.1 & 14.8 & 34.6 & 26.3 & 28.9 \\
\hline Others & 6.3 & 8.7 & 7.6 & 7.5 & 17.7 & 11.4 & 10.3 & 11.1 \\
\hline TOTAL & 100 & 100 & 100 & 100 & 100 & 100 & 100 & 100 \\
\hline
\end{tabular}

Source: BNB and WB staff calculations.

Last but not least, the time needed to establish a viable export operation was probably longer in the late 1990s than it would have been during the initial stages of transition in Bulgaria had Bulgaria stayed the reform course as other early radical reformers of Central Europe. Although with the change of government in 1997, triggered by the financial crisis of 1996, Bulgaria's path of transformation converged to that shared by most advanced reformers, initial opportunities were irreversibly squandered. For instance, a good example of opportunities that were either lost or subsequently could not be tapped relatively quickly is electrical engineering and computers. Products of electrical engineering and electronics industry in total exports accounted for 28 percent in 1989. Without FDI inflows to provide access to quickly evolving technologies and effect restructuring, the chance of their survival in truly competitive markets was practically nonexistent. Thanks to FDI, this sector survived and expanded in CEEC-10, in particular Hungary, but stagnated and devolved in Bulgaria (Zsanyi 2004).

But there are multiple signs pointing to the reversal in industrial devolution including electrical engineering. First, FDI accounted in 1998-2003 for between 25 percent and 48 percent of Bulgaria's Gross Domestic Investment (Table 37). On average, more than one third of total investments in the Bulgarian economy were foreign investments in 2000-03. As mentioned earlier, in contrast to FDI inflows in 1998-1999, these came mainly from highly developed countries. A recent surge of high quality FDI inflows into sectors of the Bulgarian economyboth services and manufacturing - that are critical to integration into pan-European markets for higher value added products.

Second, the share of Gross Domestic Investment in GDP significantly increased over 1998-2003. So did the share of FDI in 2001-2003 increasing to almost 50 percent in 2003. On average in 2000-03, foreign investments in manufacturing amounted to 1.4 percent of the GDP. Given a small size of Bulgarian markets, a significant portion of them went into activity with 
strong potential for exports.

Table 37: Share of Gross Domestic and Foreign Direct Investment in GDP in 1998-2003 (in percent)

\begin{tabular}{|l|rrrrrr|c|}
\hline & 1998 & 1999 & 2000 & 2001 & 2002 & 2003 & Average 2000-03 \\
\hline \hline Gross Domestic Investment & 16.9 & 17.9 & 18.3 & 20.7 & 19.8 & 21.7 & 20.1 \\
Foreign Direct Investment, net & 4.2 & 6.2 & 8.0 & 5.9 & 5.8 & 10.4 & 7.5 \\
\hline of which: manufacturing & 1.4 & 3.3 & 1.4 & 1.8 & 0.5 & 1.9 & 1.4 \\
\hline Share of FDI in Gross Domestic Investment & 25.0 & 34.8 & 43.9 & 28.4 & 29.0 & 47.8 & 37.3 \\
\hline
\end{tabular}

Source: BNB and WB staff calculations.

Last but not least, while we do not have data that would allow linking exports with companies according to their ownership, there is anecdotal evidence suggesting that FDI have been responsible for recent changes in Bulgaria's export mix.

\section{B. Lesson from other transition economies: reason for optimism with a caveat}

The experience of CEEC economies provides strong support to this observation. All these economies share at least one characteristic - they all have been well endowed in skilled labor force. So has been Bulgaria. But its export pattern of factor content intensities was different, with unskilled labor intensive products towering other products since 1997. While expansion in exports of unskilled labor intensive products has characterized the adjustment in foreign trade flows following the implementation of stabilization-cum-transformation programs in other CEEC economies, subsequently, however, the gap between endowment in skilled labor and its absence in exported goods was closed. FDI flows have played critical role in it.

Indeed, exports from transition economies with higher cumulative inflows of FDI per capita tend to have larger share of manufactures in total exports and are part of flows within EUbased production and distribution networks. The value of correlation coefficient between cumulative FDI per capita and the share of manufactures in exports of CEEC-11 and SEE-5 is positive and high at 79.4 percent. Furthermore, their exports are more oriented towards skilled labor and capital intensive products. Again the share of these products in manufactured exports grows as cumulative FDI per capita increases, with the correlation of 79.1 percent. Similarly high correlation is between the level of FDI stock per capita and the participation of domestic companies in 'producer-driven' global networks. This comes as no surprise, as production in supply chains of these networks is both capital and skilled labor intensive.

The experience of other transition economies point not to one but two lessons. The first is that FDI flows into Bulgaria will be contributing to closing of the gap in factor content. The second lesson is the critical importance of sustaining structural reform effort (Kaminski 2005).

\section{Signs of change?}

Hence, if the experience of other transition economies is relevant, and there is no reason to argue otherwise, then one may expect significant increase in FDI-driven exports in the coming years, if not already in 2004-05. Inflows over 2000-03, amounting on average to almost 8 percent of the GDP, were large by any standards, albeit lower than into Czech Republic and Slovakia in the same period (see Table 35 above).

In fact, even though the share of FDI going directly to manufacturing in total FDI fell from 46 percent in 1998-99 to 20 percent in 2000-03, this should not suggest that they will have little impact on Bulgaria's trade. For starters, consider that the origins of these inflows in 1998-99 raise concern as to their quality. Second, note that these flows accounted on average for almost 2 percent of the GDP in that period. These are significant amounts similar in terms of GDP as those that went to Hungary or Poland in the 1990s. In both countries, export response came three-four years after they reached these levels. 
Furthermore, Bulgaria's services sectors critical to the establishment of environment facilitating business operations and trade have attracted very significant amounts of FDI. In 200003 the banking sector attracted the total of US\$ 1.2 billion and transport and communication US\$ 691 million. These two sectors accounted for almost of total FDI inflows over 2000-03. With such an extensive foreign presence, the quality of services offered has correspondingly improved.

As was argued earlier, there are signs indicating the transformation of Bulgaria's export offer. Although the pattern of specialization that emerged in 1997-99 has largely continued through 2000-03, there has been perceptible movement towards capital- and skilled laborintensive products. Exports of electrical machinery have begun emerging as the top performers in world markets. One expects them to remain drivers of Bulgaria's EU-oriented exports in the coming years provided there is no significant change in commitment to reforms and sound policies.

\section{Conclusions}

The main results of the empirical analysis of industrial restructuring as captured in foreign trade may be summarized as follows:

$\Rightarrow$ Although the pattern of specialization in unskilled labor intensive, low technology products largely continued through 2000-03, there are indications of the ongoing shift towards patterns typical of more developed CEEC-8 countries with similar endowments in production factors.

$\Rightarrow$ Changes in import demand and export offer suggest that the process of industrial restructuring has at last begun.

o The share of manufactures in Bulgaria's trade has not only significantly increased but, within manufactures, there has been the shift towards products with higher technology content and capital goods.

o The fall in the share of traditional inputs, i.e., products used for further processing, in Bulgaria's exports has been accompanied by a marked increase in the share of machinery. This, combined with the increase of more technologically advanced manufactures in Bulgaria's exports, suggests a gradual shift towards more processed exports.

o New exports come mainly from restructured industrial capacities auguring well for future competitiveness in international markets. Recent star performers in EU-15 markets, now accounting for 16 percent of Bulgaria's exports up from 4 percent in 2000, are mainly electro-engineering products. Exports of machinery top the list, contributing almost 40 percent to the total of top performers' exports.

$\Rightarrow$ The process of realignment in allocation of resources in response to economic opening offered European markets as well as Bulgaria's potential comparative advantage in skilled labor intensive products has begun impacting Bulgaria's export basket.

o While 1996-2000 witnessed little or no gains in overall competitiveness of Bulgarian producers in world markets, except for clothing mainly in EU markets, there was a significant increase in the presence of Bulgarian exporters in the most recent period, especially in 2003.

o Capital and labor have been moving to more sophisticated and higher value added activities and more processed goods with higher content of capital and skilled labor have been expanding faster than traditional inputs and unskilled labor intensive products. 
o The gap between CEEC-8 economies and Bulgaria in terms of export performance and its factor embodiments appears to be closing, albeit slowly, as exports of capital- and skilled-labor intensive products have begun growing.

o Among emerging fast growers, i.e., products whose exports growth exceeded annual changes in EU import demand by at least 30 percent in 2000-03, capital intensive products have stood out.

$\Rightarrow$ While overall Bulgaria has a long way to catch up with other CEEC-10 economies in terms of participating in "producer-driven" network trade, there were healthy symptoms of growth in 2001-03.

$\Rightarrow$ The ongoing shift towards furniture (or more exactly furniture parts) within 'buyer-driven' networks' exports, ICT final products and automotive parts within 'producer-driven' exports and strong expansion of exports of other parts and engineering products point to significant progress in industrial restructuring and ensuing gains in competitiveness. Although Bulgarian producers have not yet become part on any significant scale of the division of labor based on production fragmentation in vertically integrated sectors, they have made significant strides in information communication technology products and automotive parts.

$\Rightarrow$ The returns usually associated with liberal reforms, i.e., gains in competitiveness combined with shift towards in products in line with country's endowments in production factors began to surface only recently. In contrast to the period preceding the second transformational recession, gains in competitiveness derive from corporate and industrial restructuring and not from subsidies.

$\Rightarrow$ Growing presence of foreign-owned firms and significant penetration by foreign capital of services sectors augurs well for export-oriented restructuring of the Bulgarian economy.

While this paper has not directly addressed barriers stemming from weaknesses in the regulatory environment as it pertains to conducting business and assuring smooth functioning of services links indispensable for participation in global division of labor based on production fragmentation, the challenge facing policy makers boils down to removing various barriers that still prevent moving to higher value added integration into pan-European markets. Ultimately, whether positive changes observed during the current phase of export expansion will continue hinges critically on staying the reform course. 


\section{References:}

Bernard, Andrew B. and J. Bradford Jensen. 1999. "Exceptional exporter performance: cause, effect, or both?” Journal of International Economics. 47:1-25.

Blomström, Magnus and Ari Kokko. 1998. "Multinational Corporations and Spillovers,” Journal of Economic Surveys, 12(2): 1-31.

Blonigen, Bruce A. 2001. "In search of substitution between foreign production and exports" Journal of International Economics, 53: 81-104.

Bruno, Michael. 1994. "Stabilization and Reform in Eastern Europe: A Preliminary Evaluation," in Olivier Jean Blanchard, Kenneth A. Frost and Jeffrey D. Sachs, eds. The Transition in Eastern Europe. Vol. I: Country Studies, The University of Chicago Press, Chicago and London, pp. 19-49.

Claessens, Stijn and R. Kyle Peters, Jr. 1997. "State Enterprise Performance and Soft Budget Constraint: the case of Bulgaria,” Economics of Transition No. 5. European Bank for Reconstruction and Development, November, pp. 305-322.

Dobrinsky, Rumen. 1997. “Transition Failures: Anatomy of the Bulgarian Crisis,” The Vienna Institute for Comparative Economic Studies Paper 236, Vienna, April.

Dobrinsky, Rumen. 1996. "Monetary Policy, Macroeconomic Adjustment and Currency Speculation under Floating Exchange Rate Regime: The Case of Bulgaria," Economics of Transition, vol. 4, no. 1 (May), pp. 185-210.

Dobrinsky, Rumen. 1995. "Economic transformation and the changing patterns of European EastWest Trade?,” in Rumen Dobrinsky and Michael Landesmann, eds., Transforming Economies and European Integration, Edward Elgar, Aldershot, UK and Brookefield, US (86-115).

Dobrinsky, R. and I. Yaneva. 1997. "Impediments to exports in small transition economies: the case of Bulgaria,” Moct - Most: Economic Policy in Transitional Economies (Netherlands) No. 2 (33-55).

Falcetti, Elisabetta, Peter Sanfey and Sladjana Tepic. 2004. "South-Eastern Europe: Opportunities and Potential for Growth,” paper presented at ONeB Conference on European Integration, 28-30 November.

Feenstra, Robert C. 1998. "Integration of Trade and Disintegration of Production in the Global Economy.” Journal of Economic Perspectives, vol. 12, number 4 (31-50).

Fischer, Stanley and Ratna Sahay. 2000. “Economies in Transition. Taking Stock.” Finance \& Development. September $(2-6)$.

Hamilton, Carl B, and L. Alan Winters. 1992. "Trade with Eastern Europe," Economic Policy, April.

Kaminski, Bartlomiej. 2005. "Bulgaria’s Institutions and Policies: Integrating into Pan-European Markets," mimeo, The World Bank, March.

Kaminski, Bartlomiej. 2004. "Production Fragmentation and Trade Integration in Enlarged Europe: How MNCs Have Succeeded Where CMEA Had Failed.” Papeles del Este: Transiciones poscommunistas. No. 9.

Kaminski, Bartlomiej. 1993. "How the Market Transition Affected Export Performance in the Central European Economies.” Policy Research Working Paper 1179, The World Bank, Washington DC, September. 
Kaminski, Bartlomiej, Zhen Kun Wang and L. Alan Winters. 1996. Foreign Trade in the Transition. The International Environment and Domestic Policy, Studies of Economies in Transition, vol. 20., The World Bank, Washington, D.C.

Landesmann, M. and R. Stehrer. 2003. "Structural Patterns of East-West European Integration: Strong and Weak Gershenkron Effects, in WIIW Structural Report 2003 on Central and Eastern Europe, Vol. 1, The Vienna Institute for International Economic Studies, Vienna.

Markusen, James R. 1998. "Multinational Firms, Location and Trade,” The World Economy. Vol. 21. No. 6. August (733-756).

Mihov, Ilian. 1999. “The Economic Transition in Bulgaria 1989-1999,” paper presented at the Fifth Dubrovnik Conference on Transition Economies, Dubrovnik, Croatia, June.

Szanyi, Miklós. 2004. “Competitiveness and Industrial Renewal.” Paper presented at the Seminar "Foreign Direct Investment and Multinational Corporations in Enlarged Europe," Universidad Complutense de Madrid, Madrid, 22-23 November.

UNCTAD. 2002. World Investment Report: Transnational Corporations and Export Competitiveness. United Nations: New York and Geneva.

Winters, L Alan. 1997. 'The Economics of “Catching up” Revisited', The Vienna Institute for Comparative Economic Studies, Reprint Series, No. 168, June.

World Bank. 1999. Czech Republic: Toward EU Accession. A World Bank Country Study, The World Bank, Washington D.C.

Wyzan, Michael. 1998. “The Political Economy of Bulgaria’s Peculiar Post-Communist Business Cycle.” Comparative Economic Studies, 40(1), Spring (pp. 5 - 42). 